University of Nebraska - Lincoln

DigitalCommons@University of Nebraska - Lincoln

\title{
Soil Genesis on the Island of Bermuda in the Quaternary: The Importance of African Dust Transport and Deposition
}

\author{
Daniel R. Muhs \\ U.S. Geological Survey, dmuhs@usgs.gov \\ James R. Budahn \\ U.S. Geological Survey \\ Joseph M. Prospero \\ University of Miami \\ Gary Skipp \\ U.S. Geological Survey, gskipp@usgs.gov \\ Stanley R. Herwitz \\ UAV Collaborative
}

Follow this and additional works at: https://digitalcommons.unl.edu/usgsstaffpub

Part of the Geology Commons, Oceanography and Atmospheric Sciences and Meteorology Commons, Other Earth Sciences Commons, and the Other Environmental Sciences Commons

Muhs, Daniel R.; Budahn, James R.; Prospero, Joseph M.; Skipp, Gary; and Herwitz, Stanley R., "Soil Genesis on the Island of Bermuda in the Quaternary: The Importance of African Dust Transport and Deposition" (2012). USGS Staff -- Published Research. 738.

https://digitalcommons.unl.edu/usgsstaffpub/738

This Article is brought to you for free and open access by the US Geological Survey at DigitalCommons@University of Nebraska - Lincoln. It has been accepted for inclusion in USGS Staff -- Published Research by an authorized administrator of DigitalCommons@University of Nebraska - Lincoln. 


\title{
Soil genesis on the island of Bermuda in the Quaternary: The importance of African dust transport and deposition
}

\author{
Daniel R. Muhs, ${ }^{1}$ James R. Budahn, ${ }^{1}$ Joseph M. Prospero, ${ }^{2}$ Gary Skipp, ${ }^{1}$ \\ and Stanley R. Herwitz ${ }^{3}$ \\ Received 4 February 2012; revised 13 July 2012; accepted 16 July 2012; published 1 September 2012.
}

[1] The origin of terra rossa, red or reddish-brown, clay-rich soils overlying high-purity carbonate substrates, has intrigued geologists and pedologists for decades. Terra rossa soils can form from accumulation of insoluble residues during dissolution of the host limestones, addition of volcanic ash, or addition of externally derived, long-range-transported (LRT) aeolian particles. We studied soils and paleosols on high-purity, carbonate aeolianites of Quaternary age on Bermuda, where terra rossa origins have been debated for more than a century. Potential soil parent materials on this island include sand-sized fragments of local volcanic bedrock, the LRT, fine-grained $(<20 \mu \mathrm{m})$ component of distal loess from the lower Mississippi River Valley, and LRT dust from Africa. These parent materials can be characterized geochemically using trace elements that are immobile in the soil-forming environment. Results indicate that local volcanic bedrock on Bermuda has Sc-Th-La, $\mathrm{Cr}-\mathrm{Ta}-\mathrm{Nd}$, and $\mathrm{Eu} / \mathrm{Eu}^{*}, \mathrm{La}_{\mathrm{N}} / \mathrm{Yb}_{\mathrm{N}}, \mathrm{Gd}_{\mathrm{N}} / \mathrm{Yb}_{\mathrm{N}}$ that can be distinguished from African dust and lower Mississippi River valley loess. Bermuda soils have Sc-Th-La, Cr-Ta-Nd, and Eu/ $\mathrm{Eu}^{*}, \mathrm{La}_{\mathrm{N}} / \mathrm{Yb}_{\mathrm{N}}, \mathrm{Gd}_{\mathrm{N}} / \mathrm{Yb}_{\mathrm{N}}$ that indicate derivation from a combination of LRT dust from Africa and local volcanic bedrock. Our results indicate that soils on islands in a very broad latitudinal belt of the western Atlantic margin have been influenced by African LRT dust inputs over much of the past $\sim 500 \mathrm{ka}$.

Citation: Muhs, D. R., J. R. Budahn, J. M. Prospero, G. Skipp, and S. R. Herwitz (2012), Soil genesis on the island of Bermuda in the Quaternary: The importance of African dust transport and deposition, J. Geophys. Res., 117, F03025, doi:10.1029/2012JF002366.

\section{Introduction}

[2] The origin of red or reddish-brown, clay-rich soils (terra rossa) overlying high-purity carbonate substrates, primarily in subtropical and tropical regions, has been a subject of curiosity for pedologists and geologists for more than a century [Durn, 2003; Schaetzl and Anderson, 2005; Singer, 2007]. Terra rossa soils are red $(2.5 \mathrm{YR}, 10 \mathrm{R})$ or reddish brown to reddish yellow (5YR, 7.5YR), clay-rich soils on carbonate substrates (limestone or dolomite). Commonly, terra rossa soils have sharp contacts with the underlying limestone or dolomite and often fill solution cavities within the carbonate bedrock. They have highly variable thicknesses, depending on landscape position, with thicker soils typically found in low-lying portions of the landscape. Terra rossa soils are found along many of the continental shores and islands of the seasonally moist Mediterranean basin,

\footnotetext{
${ }^{1}$ U.S. Geological Survey, Denver, Colorado, USA.

${ }^{2}$ Rosenstiel School of Marine and Atmospheric Sciences, University of Miami, Miami, Florida, USA. USA.

${ }^{3}$ UAV Collaborative, NASA Research Park, Moffett Field, California,

Corresponding author: D. R. Muhs, U.S. Geological Survey, MS 980, Box 25046, Federal Center, Denver, CO 80225, USA. (dmuhs@usgs.gov)

C2012. American Geophysical Union. All Rights Reserved. 0148-0227/12/2012JF002366
}

parts of Australia, and in continuously humid climates in the Western Hemisphere along an irregular latitudinal distribution from unglaciated parts of the Midwestern USA south to Florida, the Bahamas and Jamaica. They are also found on the island of Bermuda (Figure 1), the subject of the present study, where they rest on fairly pure carbonate aeolianites of Quaternary age. Terra rossa soils and paleosols are the primary basis by which the Quaternary stratigraphy of Bermuda has been defined.

[3] In the debate on the origin of terra rossa soils, Singer [2007] distilled the genetic concepts into three theories. These genetic pathways are: (1) the "residue theory," where such soils are derived from residual accumulation of the non-carbonate fraction, or impurities of the host carbonate substrate; (2) the "ascending sesquioxide theory," where Fe and Al-hydroxides build up in the soil by capillary ascent from the host rock; and (3) the "allochtonic accretion theory," where most, if not all, of the soil builds up from outside sediment sources, most commonly thought to be from finegrained aeolian accretion. By far, the greatest number of terra rossa studies fall into tests of either the "residue theory" or the "allochtonic accretion theory" categories. Muhs et al. [2010a] reviewed studies by the advocates of these alternative pedogenic pathways and it is clear that both have evidence in their favor, depending on location. Indeed, some terra rossa soils 


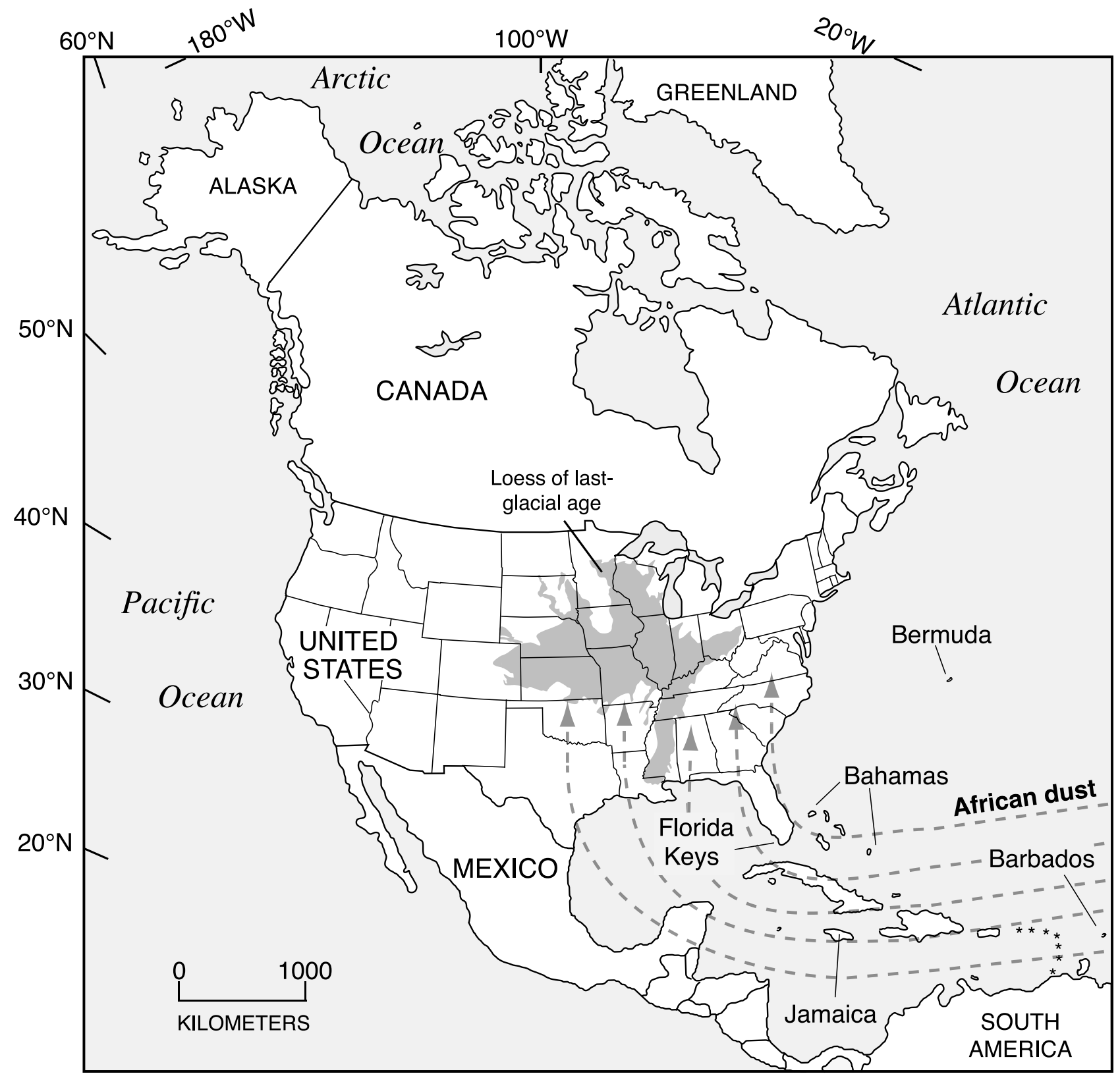

Figure 1. Map of North America showing location of Bermuda, distribution of last-glacial-age (Peoria) loess [from Bettis et al., 2003, and references therein], pathways of African dust transport to the Western Hemisphere [Perry et al., 1997; Muhs et al., 2007a], and other localities referred to in the text.

have probably formed by both processes, as they are not mutually exclusive.

[4] Soils and paleosols on Bermuda are visually striking. Bermuda soils have the classic terra rossa type of morphology, with B horizons rich in clays and Fe-oxyhydroxides, giving them red, reddish-brown, or reddish-yellow colors (2.5YR, 5YR, or 7.5YR hues) that contrast strongly with subjacent, white or gray aeolianites that are dominated by carbonate minerals (calcite and aragonite). In addition, all investigators who have studied Bermuda's soils have noted the presence of soil-filled solution pipes. Although some early workers interpreted these features as fossil palmetto stumps, Herwitz [1993] showed that they are solution features that result from concentrated stemflow waters of tree species that can acidify rainwater. The common occurrence of soil-filled solution pipes on Bermuda may help explain the persistence of the residue theory advocated by so many investigators over the years.

[5] The origin of soils and paleosols on Bermuda has been debated vigorously for more than a century. Thompson [1878], Verrill [1902], Sayles [1931], Bretz [1960], Blackburn and Taylor [1969], and Prognon et al. [2011] all considered the soils on Bermuda to be residual, the products of significant aeolianite dissolution and accumulation of the non-carbonate minerals. On Bermuda, the non-carbonate component of the aeolianites consists of volcanic particles derived from the underlying basement rock of the island. Ruhe et al. [1961], Land et al. [1967], Bricker and Mackenzie 


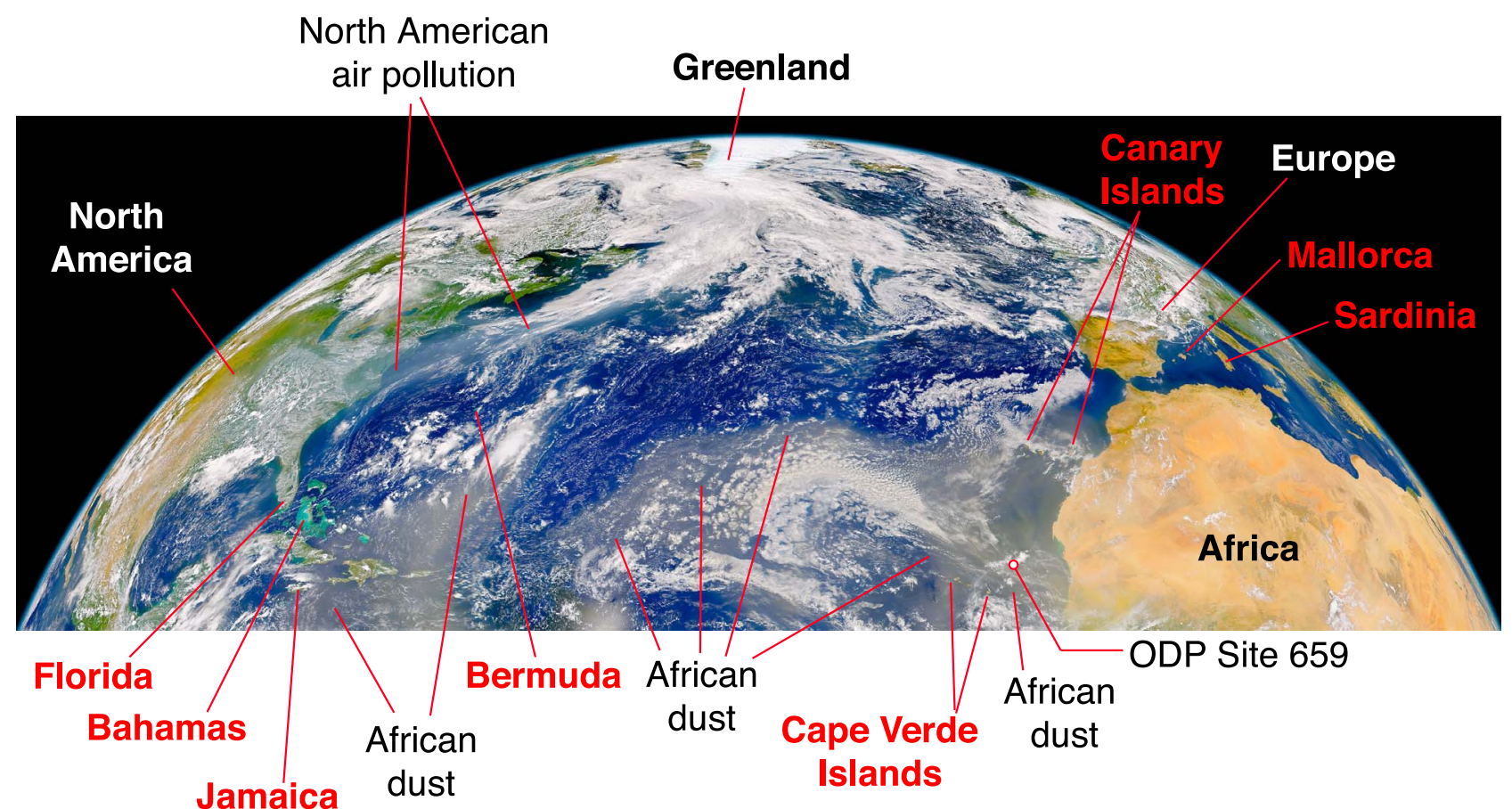

Figure 2. SeaWiFS image (May, 2001) of dust from Africa crossing the Atlantic Ocean in May, 2001. Localities in red are those islands where inputs of African dust to soils have been identified [Rognon et al., 1996; Muhs et al., 2007a, 2010a, 2010b; Muhs and Budahn, 2009; this study]. Also shown is the approximate location of ODP Site 659 (Figure 20). Image courtesy of the SeaWiFS Project of NASA/Goddard Space Flight Center.

[1970], Herwitz and Muhs [1995], and Herwitz et al. [1996], on the other hand, pointed out the problems associated with this mode of origin, including the fact that while Bermudan aeolianites are not pure $\mathrm{CaCO}_{3}$, the amount of non-carbonate material is so small that extraordinary amounts of carbonate dissolution would be required to generate the thicknesses of observed soil. Herwitz et al. [1996] suggested that longrange-transported (LRT) dust, either from Africa or North America (or both) could have supplied much of the finegrained, non-carbonate parent material for Bermudan soils.

[6] There is ample direct evidence that at present LRT dust from Africa reaches the western Atlantic Ocean, even to latitudes as far north as Bermuda (Figure 2). During the 1989-1998 decade, a dust collection program was undertaken at Bermuda [Sholkovitz et al., 1993; Arimoto, 2001; Arimoto et al., 1992, 1995, 2003; Prospero, 2002], complementary to the longer-term African dust sampling programs conducted on Barbados and in Miami [Prospero, 1999; Prospero and Carlson, 1972; Prospero and Nees, 1977, 1986, 1987; Prospero and Lamb, 2003; Prospero et al., 1970, 1981, 1987, 2001]. Results of the dust collection program on Bermuda indicate that this island shows the same seasonal cycle of dust delivery to the western Atlantic Ocean in summer that characterizes Miami, Florida and Barbados (Figure 3). The amounts of dust transported vary as a function of latitude, however, with Barbados having the highest concentrations, lower concentrations at Miami, and lowest concentrations at Bermuda. Similarly, the dust transport season is longest at Barbados, intermediate at Miami and shortest at Bermuda. The seasonal variability of dust concentrations observed at these sites is consistent with the

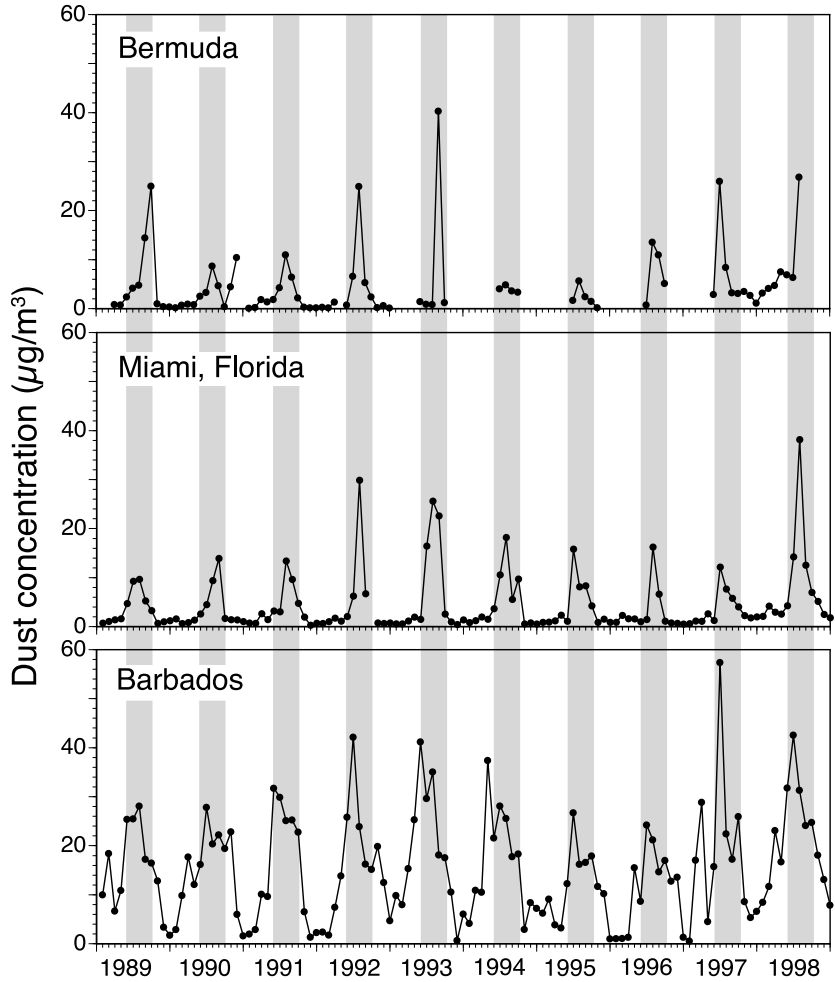

Figure 3. Monthly dust concentrations from 1989 to 1998 at Barbados and Miami, Florida [Prospero and Lamb, 2003] and Bermuda (this study, but see also Arimoto [2001]). Shaded areas highlight the May-September African dust transport season to the western Atlantic Ocean. 
(a) Modern:

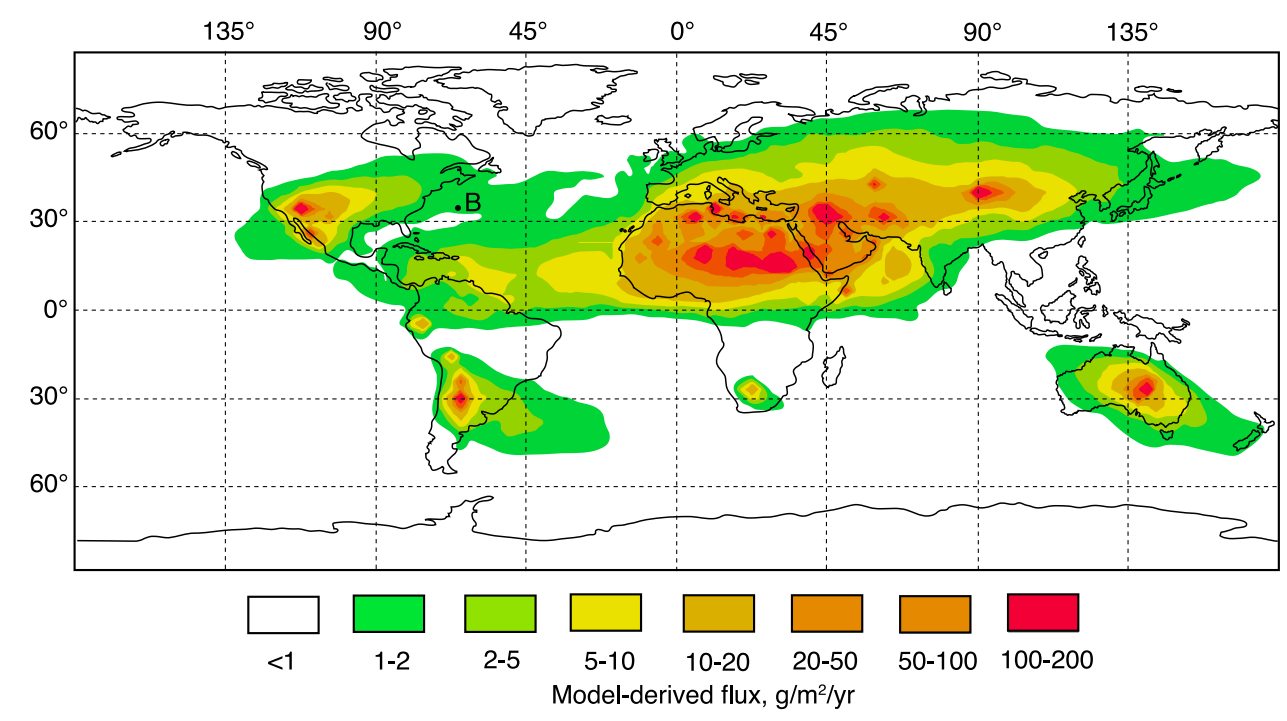

(b) Last-glacial period:

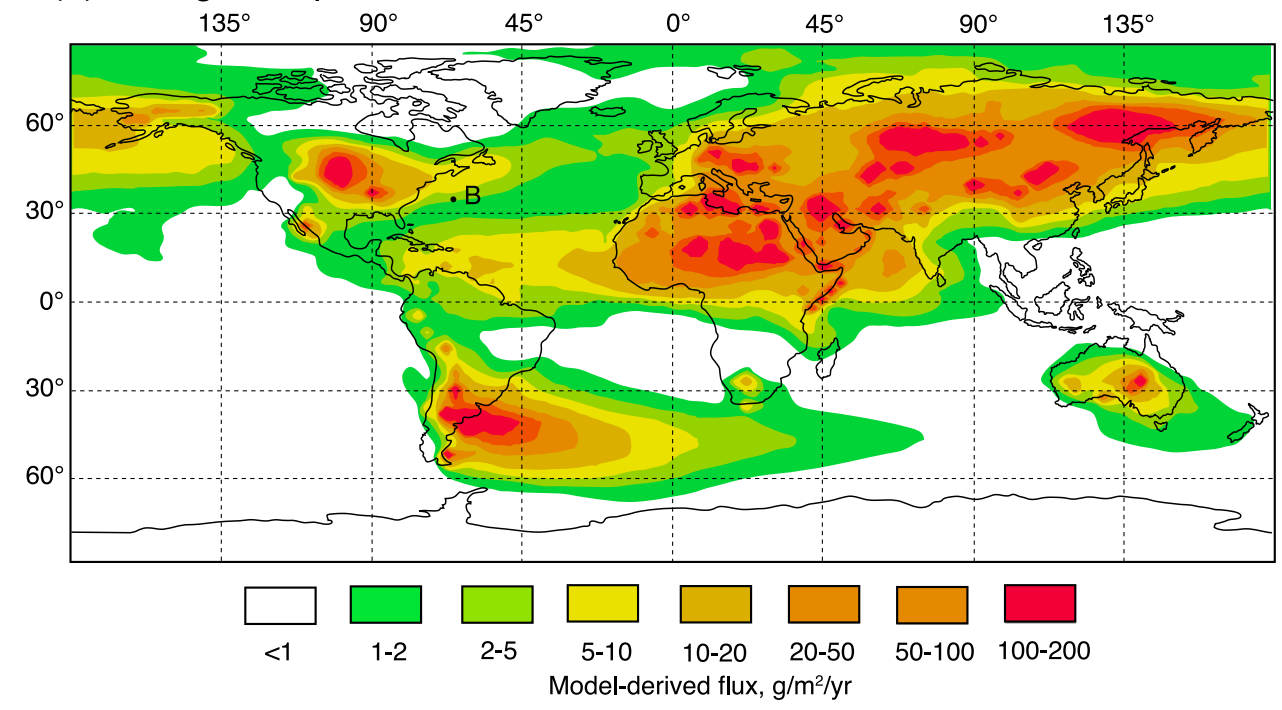

Figure 4. Modeled dust flux under (a) modern and (b) last-glacial climate conditions; note location of Bermuda (B). Dust flux maps redrawn from Mahowald et al. [2006].

seasonal variability of satellite-measured aerosol optical depth, which over much of the North Atlantic is attributed to African dust [Husar et al., 1997]. Records of dust concentrations showing the same seasonal maxima at widely separated locations indicate a common African source and synoptic control of the transport process in the lower atmosphere.

[7] Bermuda occupies an interesting latitudinal position with respect to possible dust inputs when considered on glacial-interglacial timescales. Modeling of contemporary global dust flux by Mahowald et al. [2006] showed that Bermuda is situated far enough north in the western Atlantic Ocean that, in principle, dust inputs from North America are possible, primarily from sources in the southwestern USA (Figure 4a). Nevertheless, based on measurements and observations by Sholkovitz et al. [1993], Arimoto [2001], Arimoto et al. [1992, 1995, 2003] and Prospero [2002], little or no mineral dust from North America seems to reach Bermuda at present, although pollution-derived particles from North America move eastward and to the north of Bermuda (Figure 2). On the other hand, based on modeling by Mahowald et al. [2006], during the last glacial period, Bermuda could have received eastward-moving dust from North America, but primarily from the central part of the continent (Figure 4b). The dust from central North America that could have reached Bermuda during the last glacial period would be the fine-grained, distal component of loess originating from the vast mid-continent loess belt (Figure 1). Nevertheless, dust inputs from Africa to the western Atlantic Ocean also would have been greater during the last glacial period, based on the same modeling (Figure $4 b$ ).

[8] In this study, we provide a new test of the atmospheric dust versus residual hypotheses for the origin of Bermuda's soils and paleosols. We present new analyses of many of 


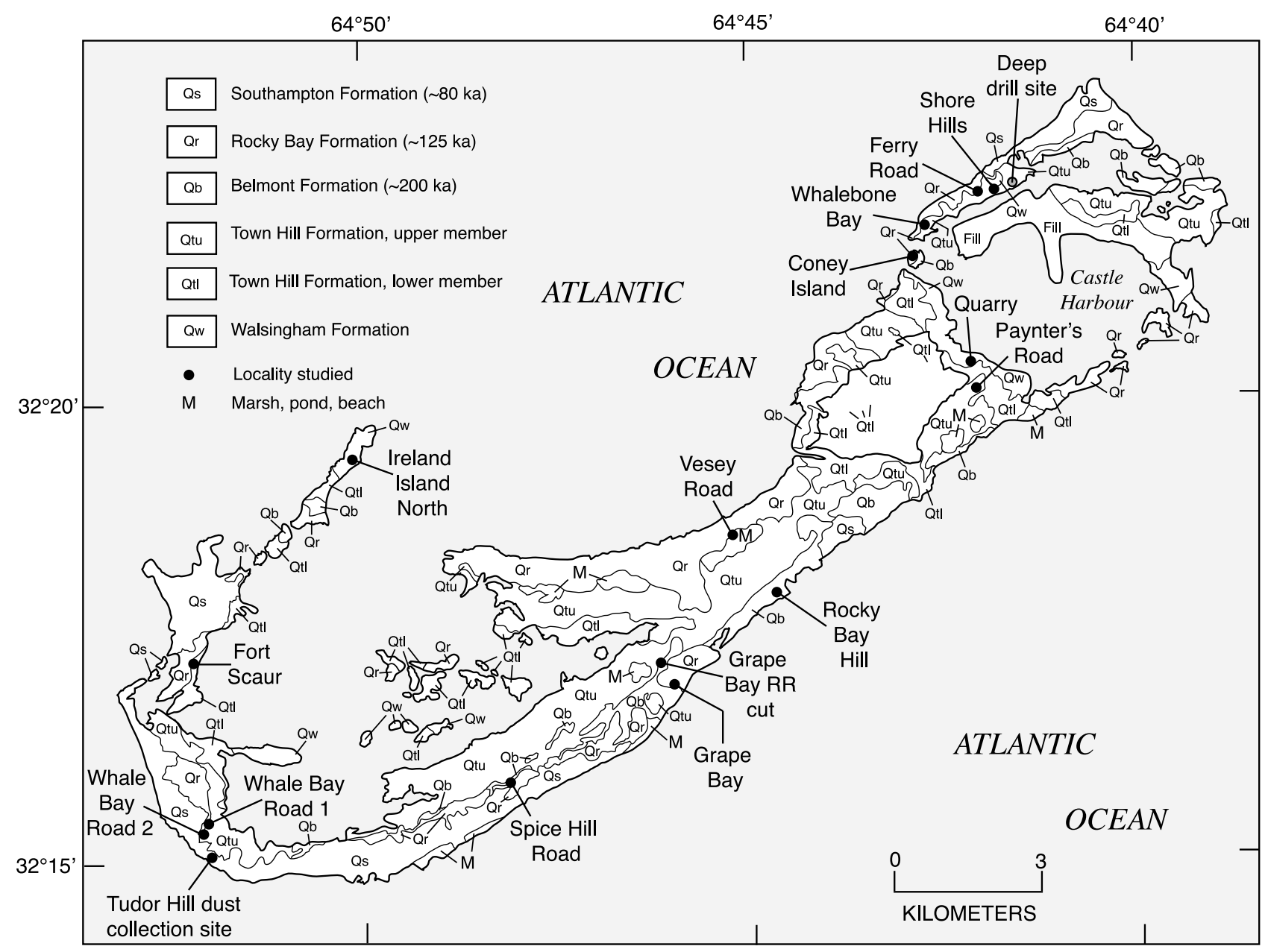

Figure 5. Geologic map of Bermuda (simplified from Vacher et al. [1989]), study localities, and location of dust trap.

the same samples reported by Herwitz et al. [1996] and provide data on new samples not previously studied. Our analyses include a much broader suite of immobile trace elements for Bermuda soils than reported by Herwitz et al. [1996]. Data for African dust collected on Barbados and the fine-grained $(<20 \mu \mathrm{m})$ portion of Mississippi River loess are drawn from our previous studies [Muhs et al., 2007a, 2010b]. However, all analyses of Bermuda soils are reported here for the first time, as are new analyses of African dust collected on Bermuda. We also present new analyses of local Bermuda volcanic rocks, including the upper part of a deep core drilled by Reynolds and Aumento [1974].

\section{Geology of Bermuda}

[9] The geology of Bermuda has been studied for more than a century and the stratigraphy has been refined periodically. Vacher et al. [1995] and Vacher and Rowe [1997] provide excellent overviews of the history of study of the island, and summaries of the Quaternary stratigraphy as it is now understood. Much of the current framework of Bermudan stratigraphy is the result of the first detailed geologic mapping of the island (Figure 5), presented by Vacher et al. [1989]. The stratigraphic nomenclature, as used in the present paper, is taken from Vacher et al. [1989, 1995] and Vacher and Rowe [1997].

[10] The island of Bermuda is the emergent portion of the Bermuda Rise, a volcanic topographic high on the western Atlantic Ocean floor. Although the presence of this volcanic pedestal has been recognized for a long time, it was not until deep drilling on the island was conducted that the composition of the island core was understood. Reynolds and Aumento [1974] reported that this drilling effort yielded $767 \mathrm{~m}$ of rock composed of $\sim 1000$ igneous units, including 600 submarine lava flows (altered tholeiites) and 400 interfingering intrusive lamprophyric sheets. The latter make up a significant portion of the igneous mass and $\mathrm{K} / \mathrm{Ar}$ ages average about $33 \mathrm{Ma}$. The older tholeiitic lavas are thought to be about the same age as the surrounding seafloor, $\sim 110 \mathrm{Ma}$. The composition of the younger, upper part of this core is unusual and we discuss this in detail later. The depth of the volcanic core below the Quaternary cover varies across the island. Typically, the volcanic/ Quaternary contact is at $\sim 50-75 \mathrm{~m}$ depth, but it is as shallow as $\sim 15 \mathrm{~m}$ [Vacher and Rowe, 1997]. The volcanic core of the island has significance for soil genesis, as particles from this rock are found in the Quaternary deposits on the island.

[11] The majority of Quaternary deposits on Bermuda are cemented carbonate dune sands, or aeolianites, a term that was coined on Bermuda itself, when Sayles [1931] studied 


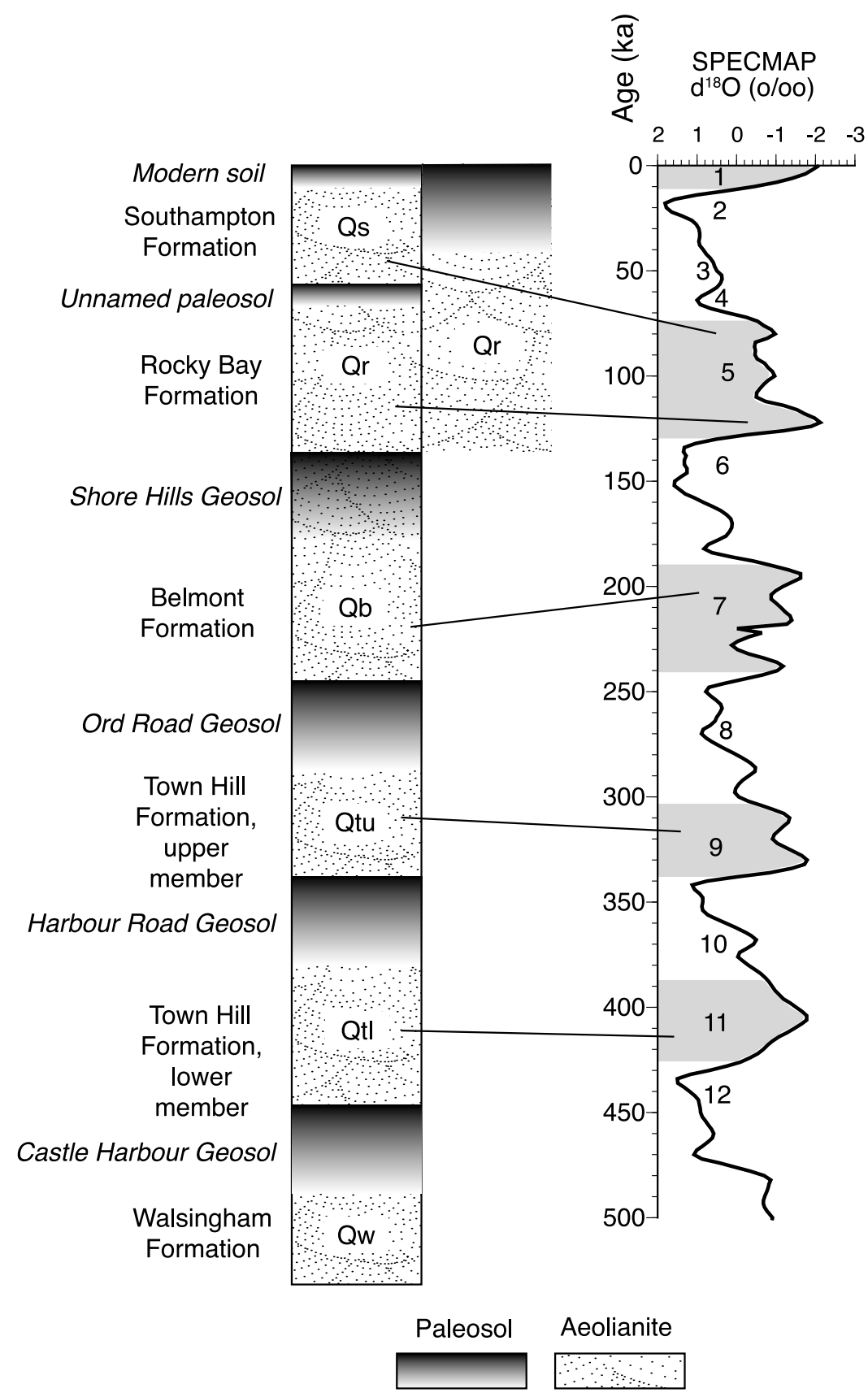

Figure 6. Generalized stratigraphic column for Bermuda showing aeolianites and "geosols" (paleosols) [Vacher et al., 1989, 1995] and proposed correlation to the deep-sea oxygen isotope record [Imbrie et al., 1984]. Shaded intervals with odd numbers indicate interglacial periods; unshaded even numbers indicate glacial periods.

these deposits. Because of their high carbonate content and degree of cementation, primary aeolian structures, particularly cross-bedding with high-angle foresets, are unusually well preserved on Bermuda [Mackenzie, 1964a, 1964b]. The aeolianites are separated vertically by paleosols (referred to as "geosols" by Vacher et al. [1989, 1995] and Vacher and Rowe [1997]) with varying degrees of development. Vacher et al. [1989, 1995] and Vacher and Rowe [1997] recognize six major aeolianite formations (Figure 6), from oldest to youngest: the Walsingham Formation $(\mathrm{Qw})$; the Town Hill Formation, with a lower member $(\mathrm{Qtl})$ and an upper member
(Qtu); the Belmont Formation (Qb); the Rocky Bay Formation (Qr); and the Southampton Formation (Qs).

[12] Although the majority of the rock bodies that make up these formations are aeolianite, there are spatially limited outcrops of marine deposits that can be traced laterally into the aeolianite facies. The marine deposits are important for two reasons. First, lateral tracing of the marine facies shoreward into the aeolian facies [Vacher et al., 1989, 1995; Vacher and Rowe, 1997] indicates that the aeolianite sands were deposited at the end of interglacial high sea stands during the Quaternary. Although this interpretation of Bermudan 
aeolianites was made as early as the studies of Bretz [1960], it is significant, because it reverses the long-standing concept of Sayles [1931] that aeolianites form during glacial periods. The newer interpretation also indicates that soil genesis, which followed aeolianite deposition, would have commenced during glacial periods. Second, fossils in the marine facies allow dating. Uranium-series dating of fossil corals in the marine facies by Land et al. [1967], Harmon et al. [1983], and Muhs et al. [2002] shows that the Belmont Formation is $\sim 200 \mathrm{ka}$ (marine isotope stage, or MIS 7), the Rocky Bay Formation is $\sim 120$ ka (MIS 5.5), and the Southampton Formation is $\sim 80 \mathrm{ka}$ (MIS 5.1). Amino acid age estimates from fossil mollusks in the older formations, calibrated to the U-series-dated units by Hearty et al. [1992], indicate possible ages of $\sim 325$ ka (Town Hill Formation, upper member), 450 ka (Town Hill Formation, lower member), and $>900 \mathrm{ka}$ (Walsingham Formation). Based on these U-series ages and amino acid age estimates, the correlation of Quaternary geologic units on Bermuda with the SPECMAP marine isotope record is summarized in Figure 6.

\section{Materials and Methods}

[13] We analyzed a suite of 30 of the 38 Bermuda soil samples reported by Herwitz et al. [1996] plus an additional 22 samples not previously analyzed. These samples come from 14 localities on the island (Figure 5). All Bermuda soil samples were analyzed in bulk, i.e., as "whole rocks," without pretreatments, other than pulverization to a uniform particle size. Concentrations of rare earth elements (REE) and other trace elements were determined by instrumental neutron activation analysis (INAA), as described by Budahn and Wandless [2002]. For provenance studies, we utilized only those elements that are considered, on the basis of high ionic potential, to be immobile in low-temperature, near-surface environments (see discussions in Muhs et al. [2007a, 2008, 2010a, 2010b] and Muhs and Budahn [2009]). The suite of elements chosen includes $\mathrm{Sc}, \mathrm{Cr}, \mathrm{Ta}$, and $\mathrm{Th}$ as well as the REE. REE concentrations are typically normalized to chondritic meteorite compositions and we have followed this protocol in the present study. All new geochemical data in this study are in Data Sets S1, S2, and S3 of the auxiliary material. ${ }^{1}$

[14] For aeolianites, we determined the total carbonate content (including high-Mg calcite, low-Mg calcite and aragonite) of 24 samples, collected from most of the 14 localities around the island shown in Figure 5 and four additional localities. Samples include aeolianites from the Southampton Formation, Rocky Bay Formation, Belmont Formation and Upper Town Hill Formation. Total carbonate content of aeolianites was determined by coulometric titration following the methods outlined by Engleman et al. [1985].

[15] We also analyzed samples of the volcanic bedrock found at shallow depths on Bermuda, from the drill core reported by Reynolds and Aumento [1974]. This core was taken near the Bermuda Biological Station for Research $\left(\mathrm{N} 32^{\circ} 22^{\prime} 13.20^{\prime \prime} ; \mathrm{W} 64^{\circ} 41^{\prime} 46.94^{\prime \prime}\right)$. At this locality, the contact between Quaternary sediments and Tertiary volcanic rock is at a depth of $\sim 33 \mathrm{~m}$. We analyzed 12 samples taken at depth intervals of $\sim 1$ to $\sim 4 \mathrm{~m}$, from $38.9 \mathrm{~m}$ to $60.4 \mathrm{~m}$. In

\footnotetext{
${ }^{1}$ Auxiliary materials are available at $\mathrm{ftp} / / \mathrm{ftp}$.agu.org/apend/jf/ 2012JF002366.
}

addition to INAA analyses for trace elements, we conducted major element analyses of these samples by wavelengthdispersive $\mathrm{X}$-ray fluorescence (XRF).

[16] Trace element compositions of 35 modern African dust samples, collected on Barbados in 1967-1969, were taken from Muhs et al. [2007a, 2010b], as were compositions of fine-grained $(<20 \mu \mathrm{m})$ loess from the lower Mississippi River valley. African dust samples were collected at Kitridge Point, Barbados (latitude $13^{\circ} 10^{\prime} \mathrm{N}$; longitude $59^{\circ} 30^{\prime} \mathrm{W}$, Figure 1) [see Prospero and Nees, 1977] for sampling details. The protocol used in the early dust-sampling program on Barbados was based on sampling of aerosols by means of a nylon monofilament screen suspended in the wind; four square meters of collector typically yielded tens of grams of dust during the dusty summer season. With such large samples, it was possible to separate the mineral dust into size classes by settling in aqueous suspensions [Prospero et al., 1970]. The size cuts used in this study were: $>20 \mu \mathrm{m}$, 20-10 $\mu \mathrm{m}, 10-5 \mu \mathrm{m}, 5-2 \mu \mathrm{m}$, and $<2 \mu \mathrm{m}$.

[17] For African dust on Bermuda itself, we utilized a suite of samples collected from 1988 to 1998 (Figure 3) at Tudor Hill, Bermuda (Figure 5). Sampling protocols for these materials are given in Arimoto [2001], Arimoto et al. [1992, 1995, 2003], Sholkovitz et al. [1993], and Prospero [2002]. Unlike African dust samples collected on Barbados, trace element compositions of dust samples collected on Bermuda are reported here for the first time. Because the concentrations of African dust in the lower troposphere surrounding Bermuda are significantly lower than around Barbados [Prospero, 2002] (see also discussion below), we had much less material to work with for geochemical analyses and therefore size fractionation was not possible. Even for bulk analyses, we encountered problems with sample size. Initially, we attempted to remove dust from the filter paper used for collection, but this resulted in significant sample loss and too little material for precise geochemical determinations. Thus, for the remaining 10 samples, we analyzed the collected dust in bulk, along with the collection filter paper, to minimize sample loss. Although this procedure does not allow us to calculate concentrations of elements of interest in the dust alone, it is still possible to calculate element ratios in the dust, because the filter paper used for collection has insignificant amounts of trace elements, based on previous studies of Bermuda dust [Sholkovitz et al., 1993, Table 3].

[18] For North American loess samples, we analyzed those sediments that were most likely to be transported to the western Atlantic Ocean during the last glacial period. These are from the lower Mississippi River Valley, the most southerly loess source on the continent (Figure 1). Unaltered loess samples, taken from depths below the zone of pedogenesis, were collected from localities in Tennessee, Mississippi and Louisiana, comprising a transect from latitudes $\sim 35^{\circ} \mathrm{N}$ to $\sim 30^{\circ} \mathrm{N}$ (detailed locality data are in Muhs et al. [2001]). Tsoar and Pye [1987] pointed out that it is the $<20 \mu \mathrm{m}$ fraction of loess that is capable of transport in long-term suspension for wide dispersal. Thus, we conducted particlesize separations of the sediments to obtain the fine-grained $(<20 \mu \mathrm{m})$ loess fraction capable of long-range transport. Muhs et al. [2007a] previously reported data for these Mississippi loess samples.

[19] Mineralogical determinations of Bermuda soils, paleosols and local volcanic rock were made by X-ray 


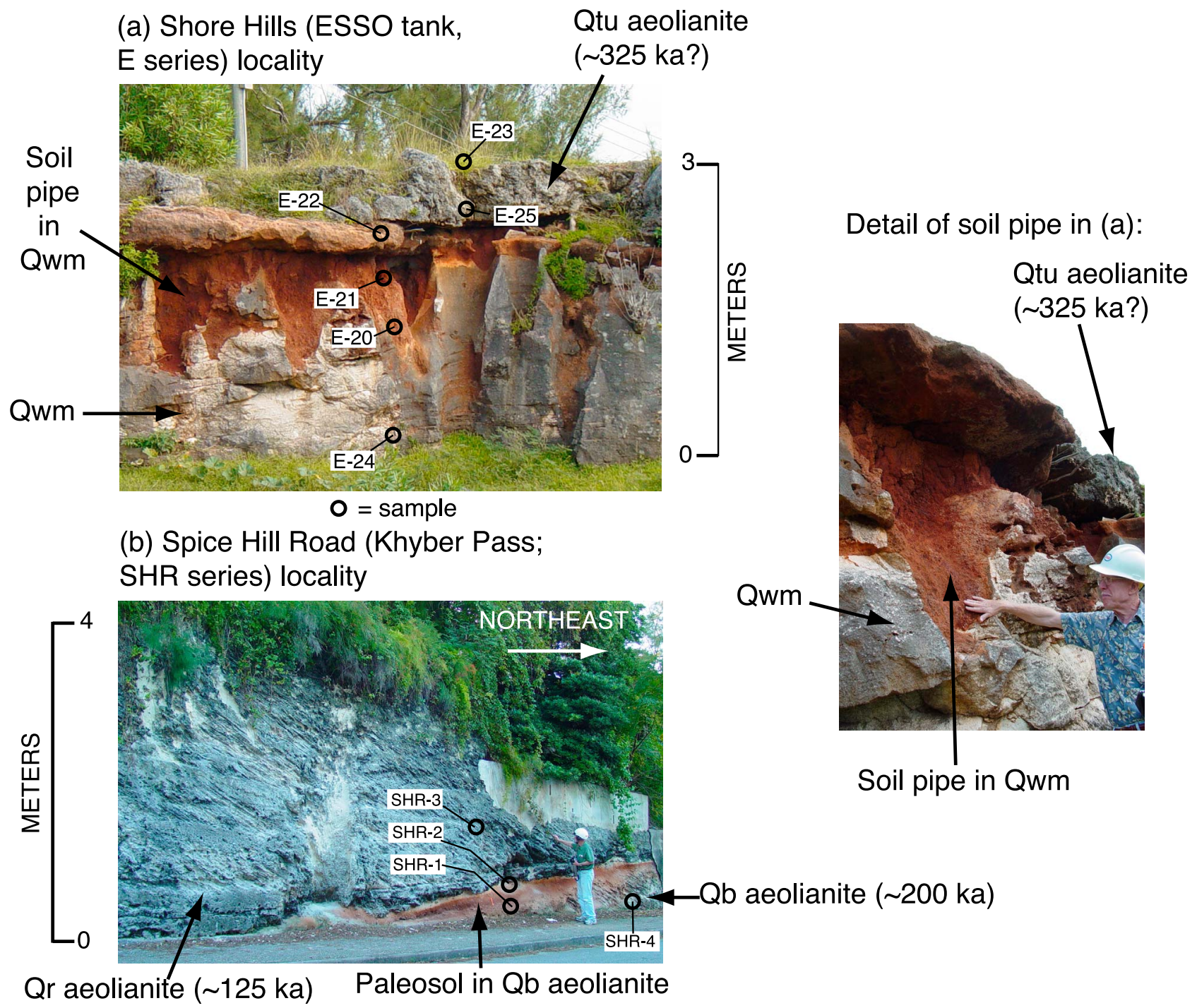

Figure 7. Photographs showing stratigraphy and sampling points (circles) at (a) the Shore Hills (ESSO Tank) locality, along with a photograph showing details of a soil pipe at this locality and (b) the Spice Hill Road (Khyber Pass) locality. Photographs courtesy of Diana Johnson and Donald Lee Johnson (next to soil pipe), University of Illinois.

diffraction (XRD) analysis. All soils, paleosols and volcanic rocks were pulverized and analyzed as bulk powders. In addition, however, we separated the clay $(<2 \mu \mathrm{m})$ fraction from soils and paleosols for XRD, because this size fraction constitutes the bulk of non-carbonate material [Ruhe et al., 1961]. Clays were isolated by sedimentation after pretreatments to remove organic matter and carbonates; dispersion was accomplished with Na-hexametaphosphate. Clay separates were X-rayed four times: air-dry, glycolated, K-saturated, and heat-treated $\left(550^{\circ} \mathrm{C}\right.$ for one hour).

\section{Quaternary Stratigraphy and Paleopedology of the Study Localities}

[20] The geologic map of Bermuda produced by Vacher et al. [1989] shows that the Quaternary stratigraphy of Bermuda is complex, and our own observations confirm this. Particularly important points to consider are that the spatial extent of aeolianite deposition varies from unit to unit, unconformities are common, and the duration of pedogenesis for both modern surface soils and paleosols varies considerably from section to section. We did not observe a complete section with all Quaternary units (Figure 6) at any locality, and most exposures display only two units. For example, at the classic "Shore Hills" locality of early workers, the marine facies of the Walsingham Formation has a very well developed paleosol in it, with red (2.5YR-5YR) hues, strong, coarse, angular blocky structure and abundant clay films in its upper part (Figure 7). The upper member of the Town Hill Formation overlies the paleosol. Thus, the well-developed paleosol between the Walsingham Formation ( $>900 \mathrm{ka}$ ?) and the upper member of the Town Hill Formation $(\sim 325 \mathrm{ka})$ probably reflects a long period of pedogenesis that spans several interglacial-glacial cycles of the early and middle Quaternary. At several localities, we observed the Rocky Bay Formation of last interglacial age $(\sim 120 \mathrm{ka})$ overlying the upper member of the Town Hill Formation ( $325 \mathrm{ka})$, with a 
(a) Ferry Road (PR series):

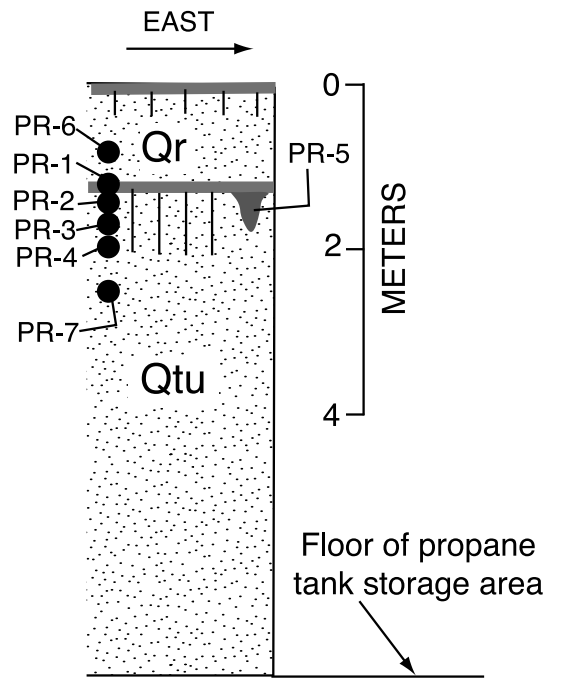

\section{EXPLANATION}

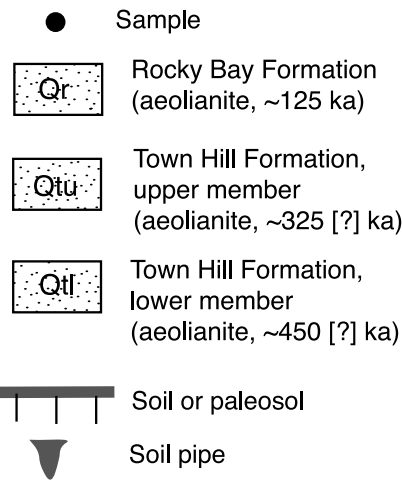

(b) Fort Scaur (FS series):

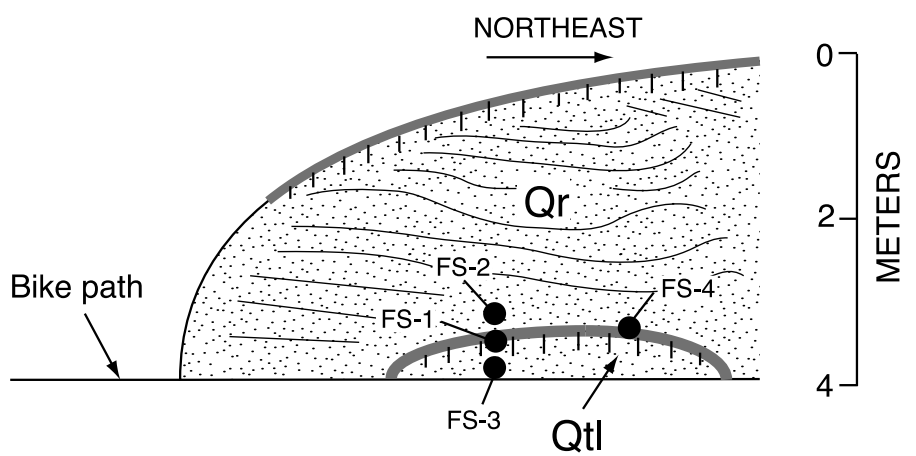

(c) Whale Bay Road 1

(Mt. Zion Church, Z series):

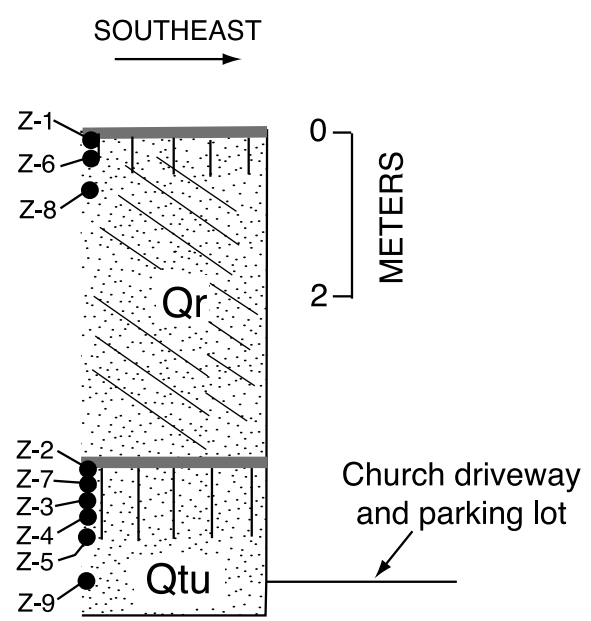

(d) Whale Bay Road 2 (ZZ series):

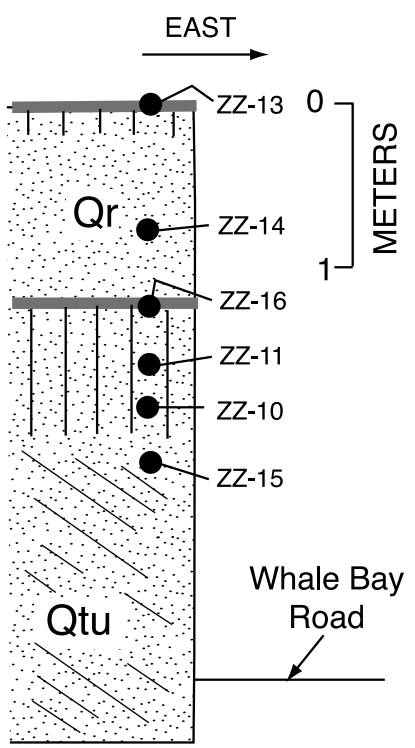

Figure 8. Stratigraphy and sampling points (circles) for the (a) Ferry Road, (b) Fort Scaur, (c) Whale Bay Road 1 (Mt. Zion church), and (d) Whale Bay Road 2 localities.

well-developed paleosol in between (Figures 8 and 9). At the Whale Bay Road 1 (Mt. Zion Church) locality, this paleosol has a Bt horizon almost $50 \mathrm{~cm}$ thick, with reddish-yellow hues (5YR 5/6-6/6), and strong, fine-to-medium, angular-to-subangular blocky structure. Although not as well developed as the paleosol at the Shore Hills locality, the paleosol between the upper member of the Town Hill Formation and the Rocky Bay Formation probably experienced pedogenesis during two glacial periods (MIS 8 and 6), as well as an intervening interglacial period (MIS 7) before being buried by aeolianite during the last interglacial period (MIS 5.5, 120 ka). At other localities, the Rocky Bay Formation (MIS 5.5, 120 ka) overlies aeolianite or marine deposits of the Belmont Formation (MIS 7, 200 ka), thus displaying deposits of the penultimate interglacial period, a paleosol representing the penultimate glacial period, deposits of the last interglacial period, and finally the modern soil developed at the surface (Figures 7, 10, and 11). Modern surface soils that developed on the Rocky Bay Formation (MIS 5.5, 120 ka) have had a duration of pedogenesis that could have spanned the latter part of MIS 5 (MIS 5.4, 5.3, 5.2, 5.1), as well as all of MIS 4,
3,2 , and 1 , including glacial, interstadial and interglacial periods. Thus, even many of Bermuda's modern surface soils, developed on the Rocky Bay Formation, one of the island's youngest aeolianites, can be well developed. For example, at the Vesey Road section, both horizontal soils and soil pipes have developed on the surface of aeolianite of the Rocky Bay Formation (Figure 9b). The soil pipes in places are as deep as $\sim 107 \mathrm{~cm}$, exhibiting an A horizon with yellowishbrown colors (10YR 6/4) and weak, fine, subangular blocky structure, as well as a Bt horizon with yellowish-red colors (5YR 5/6) and strong, coarse, prismatic or angular blocky structure.

[21] Soil truncation has occurred at a number of localities on Bermuda. A good example of this can be seen at the Grape Bay railroad cut (Figure 12). Here, aeolianite of the upper member of the Town Hill Formation was deposited and a soil formed on the surface. This soil was buried when aeolianite of the Belmont Formation was deposited (eastern part of section shown in Figure 12). A soil formed on the newly deposited Belmont Formation and, in the eastern part of the exposure, may have been developing from $\sim 200 \mathrm{ka}$ 
(a) Paynter's Road section (PY series):
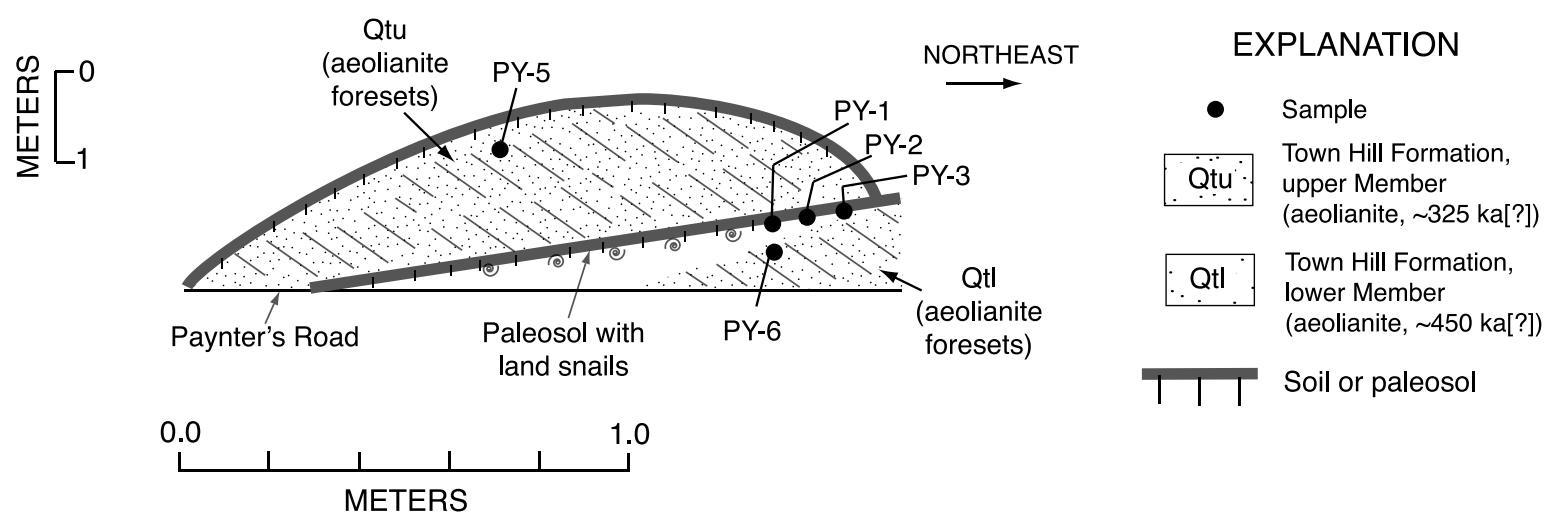

(b) Vesey Road section (EQV series):
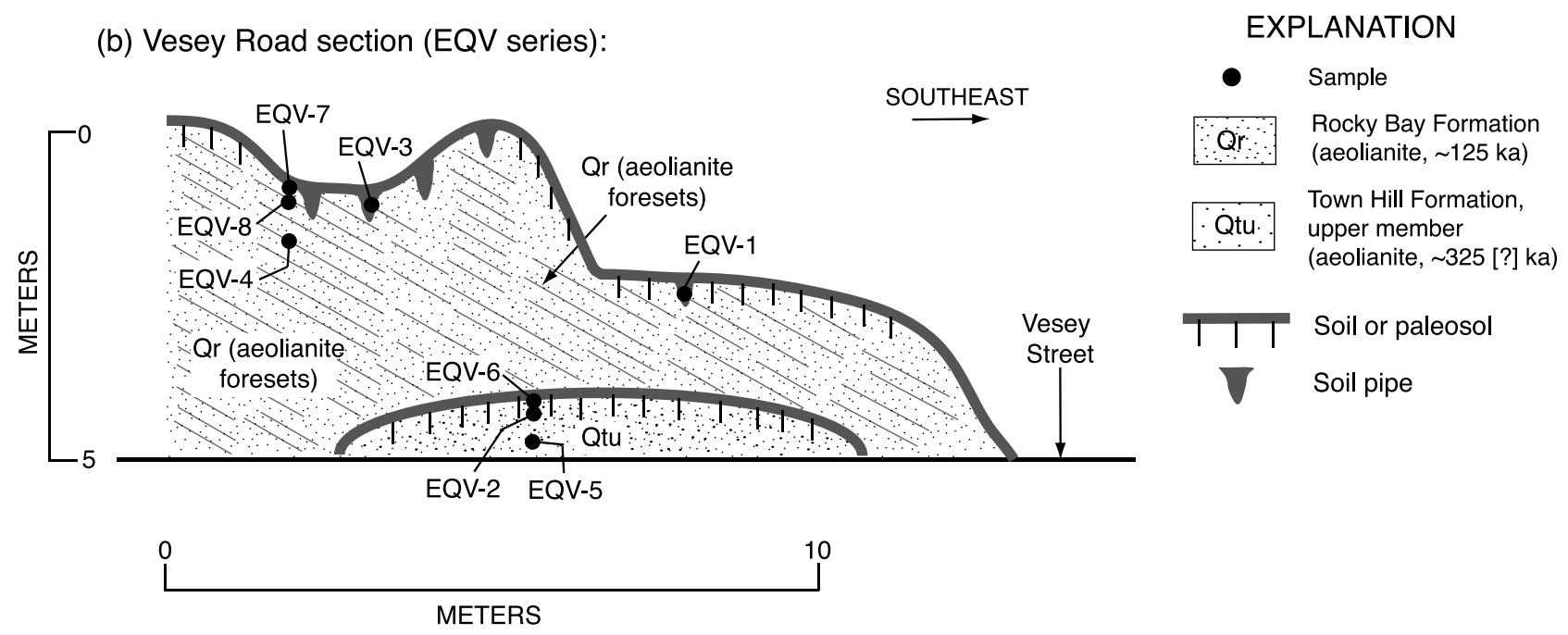

Figure 9. Stratigraphy and sampling points for the (a) Paynter's Road and (b) Vesey road localities.

to the present. In the western part of the section, however, erosion removed part of the upper member of the Town Hill Formation, probably after deposition of the Belmont Formation. This period of erosion created a concave-upward erosion surface on the upper member of the Town Hill Formation aeolianite, but was followed by a period of stability and a soil formed on the surface of the eroded Town Hill aeolianite. Later, aeolianite of the Rocky Bay Formation buried the newly formed soil and a soil formed on this youngest aeolianite, which is the surface soil visible in the western part of the exposure today. The key to recognizing this complex sequence of events is the great degree of development of the paleosol on the upper member of the Town Hill Formation aeolianite in the eastern part of the section, in contrast to the lesser degree of development of the paleosol on the same unit in the western part of the section.

\section{Mineralogy}

\subsection{Mineralogy of Potential Parent Materials}

[22] The compositions of possible parent materials for Bermuda soils differ significantly. Aeolianites, the host sediments, contain mostly carbonate minerals, aragonite and calcite. In the 24 samples of aeolianite we analyzed from around the island, carbonate content is very high, ranging from $93.8 \%$ to $98.9 \%$, with an average of $97.2 \%$. Carbonate content does not differ significantly between the four formations we analyzed. Our estimates of aeolianite carbonate content are in good agreement with those made for other aeolianite samples by Herwitz and Muhs [1995]. Although the carbonate content of Bermuda aeolianites is high, it is not $100 \%$. Sayles [1931] reported that 9 aeolianites he analyzed contained (in order of decreasing abundance) quartz, K-feldspar, perovskite, pyroxene, glass, magnetite, and garnet. This mineral suite is similar to that of Prognon et al. [2011], who identified sand-sized grains within the paleosols as quartz, perovskite, titanite, garnet, leucite, diopside, magnetite, spinel, chromite, and a phosphate mineral. At Whalebone Bay, the marine facies of the Town Hill Formation contains abundant volcanic (i.e., non-carbonate) minerals, as noted by Blackburn and Taylor [1969], Bricker and Mackenzie [1970], Herwitz et al. [1996] and Prognon et al. [2011]. A sample we collected from this unit yielded only $\sim 9.7 \%$ carbonate. 
(a) Grape Bay area:

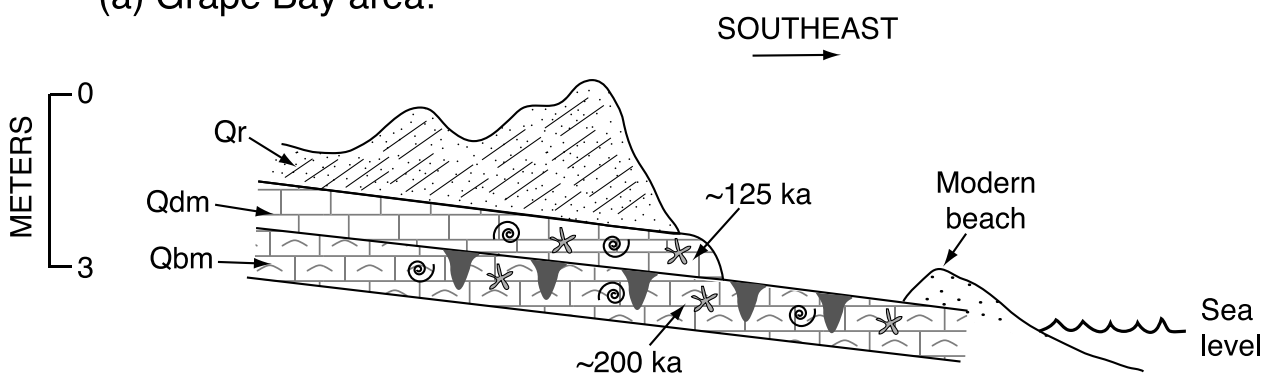

(b) Rocky Bay Hill (RBD series):

EXPLANATION
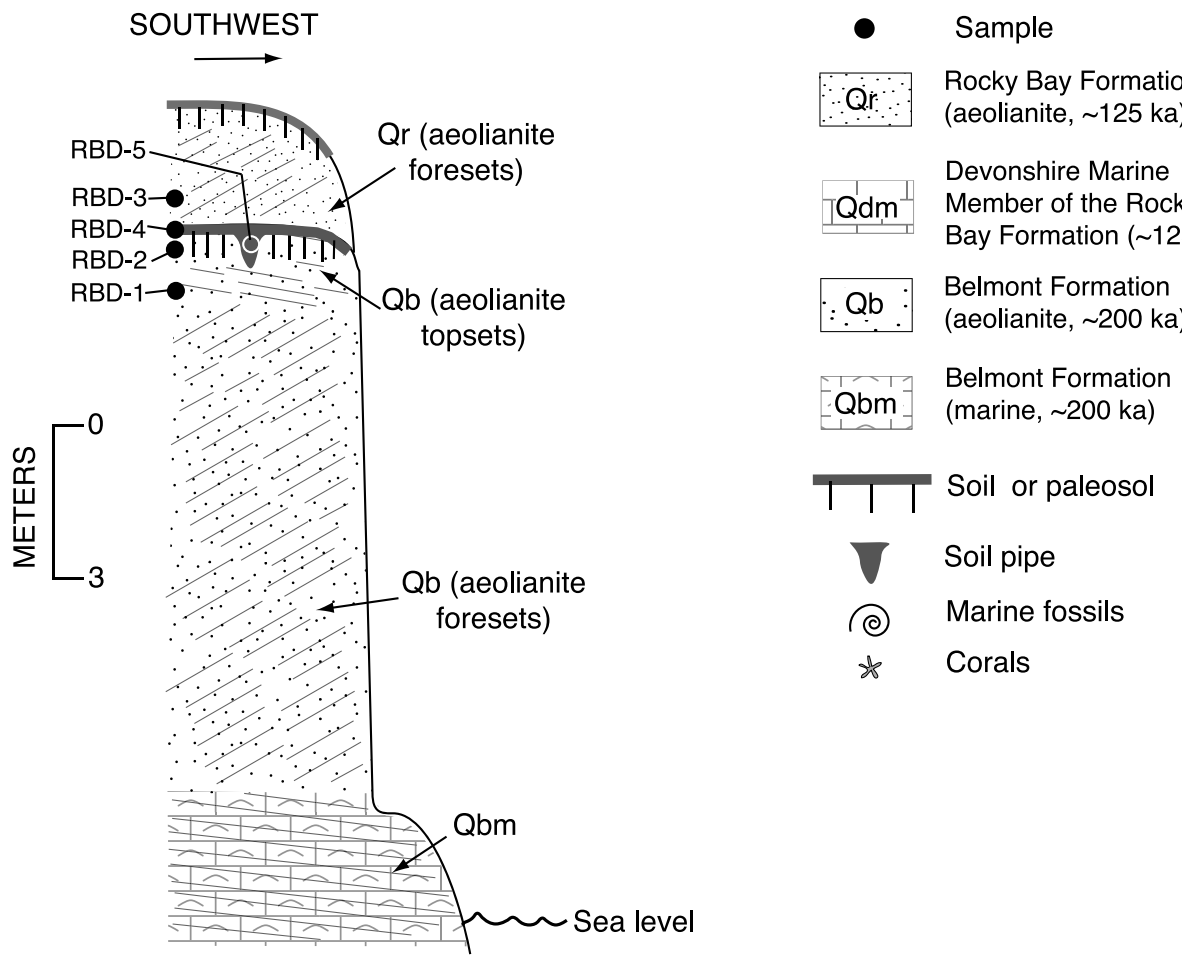

Figure 10. Stratigraphy and U-series ages on coral for (a) the Grape Bay area from Muhs et al. [2002] and stratigraphy and sampling points for (b) the Rocky Bay Hill area.

[23] The volcanic rocks that comprise the bulk of the Bermuda Rise are very likely the suppliers of the non-carbonate minerals that have been described in Bermudan aeolianites and sand-sized grains in Bermuda paleosols. For the volcanic core samples we obtained from Dalhousie University [Reynolds and Aumento, 1974], we obtained semiquantitative mineralogical data by XRD on bulk samples, augmented by major element geochemistry by XRF. Reynolds and Aumento [1974] did not specifically analyze Bermuda volcanic rocks for mineralogy, but they noted the occurrence of phlogopite, calcite, olivine, pyroxene, plagioclase and glass. Our results are similar and indicate a mineralogy that reflects a basic igneous rock that has probably undergone hydrothermal alteration and/or interaction with seawater, as suggested by Reynolds and Aumento [1974]. From depths of $\sim 39 \mathrm{~m}$ to $\sim 57 \mathrm{~m}$, we identified at least seven minerals, including magnetite, diopside, zeolite, mica (probably phlogopite), chlorite, calcite, and plagioclase. Quartz is also present at depths of $\sim 55$ and $57 \mathrm{~m}$, and olivine is present at $\sim 39 \mathrm{~m}$. In the two lower samples $(60.4 \mathrm{~m}$ and 61.5 $\mathrm{m})$, augite, diopside, chlorite, calcite, quartz and plagioclase are present. Both mineral assemblages, while unusual, are consistent with major element geochemistry. The uppermost 10 samples $\left(\sim 39 \mathrm{~m}\right.$ to $\sim 57 \mathrm{~m}$ ) have $\mathrm{SiO}_{2}$ contents of $31.8 \%$ to $39.1 \%$, with $\mathrm{Al}_{2} \mathrm{O}_{3}$ contents of $8.3 \%$ to $12.2 \%$. For these upper samples, total iron content (as $\mathrm{Fe}_{2} \mathrm{O}_{3}$ ) is $11 \%$ to $14.1 \%$, with $\mathrm{CaO}$ contents of $11.5 \%$ to $15.3 \%, \mathrm{MgO}$ contents of $6.1 \%$ to $10.2 \%, \mathrm{Na}_{2} \mathrm{O}$ contents of $1.2 \%$ to $3 \%$ and $\mathrm{K}_{2} \mathrm{O}$ contents of $1.7 \%$ to $4.4 \%$. The lower two samples have $\mathrm{SiO}_{2}$ contents of $41.2 \%$ to $46.8 \%$ and $\mathrm{Al}_{2} \mathrm{O}_{3}$ contents of $14.8 \%$. 
(a) Coney Island (CN series):

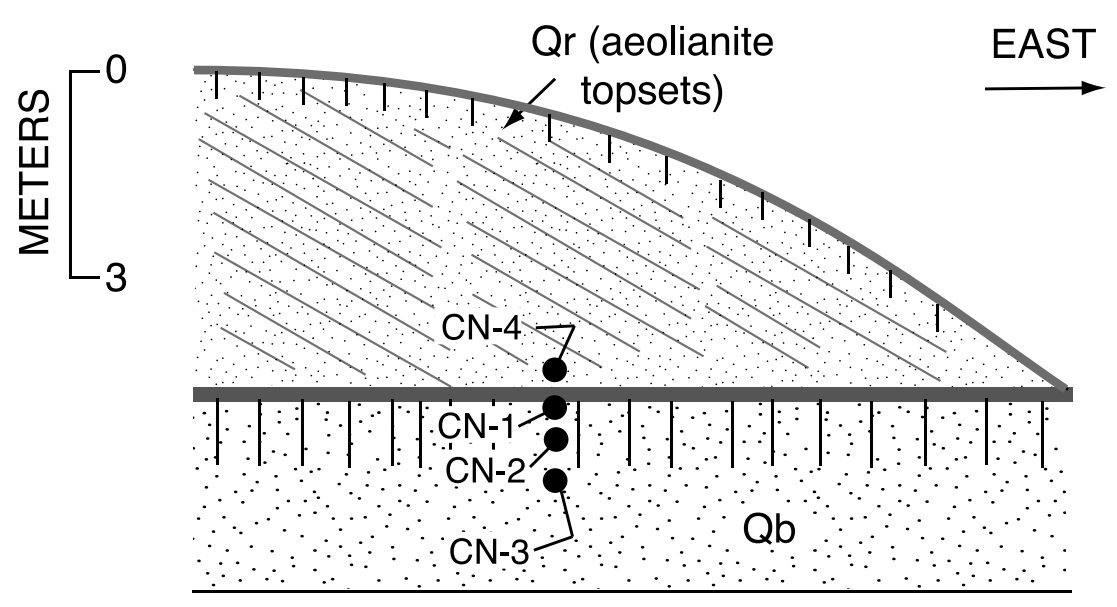

(b) Whalebone Bay area (W series):

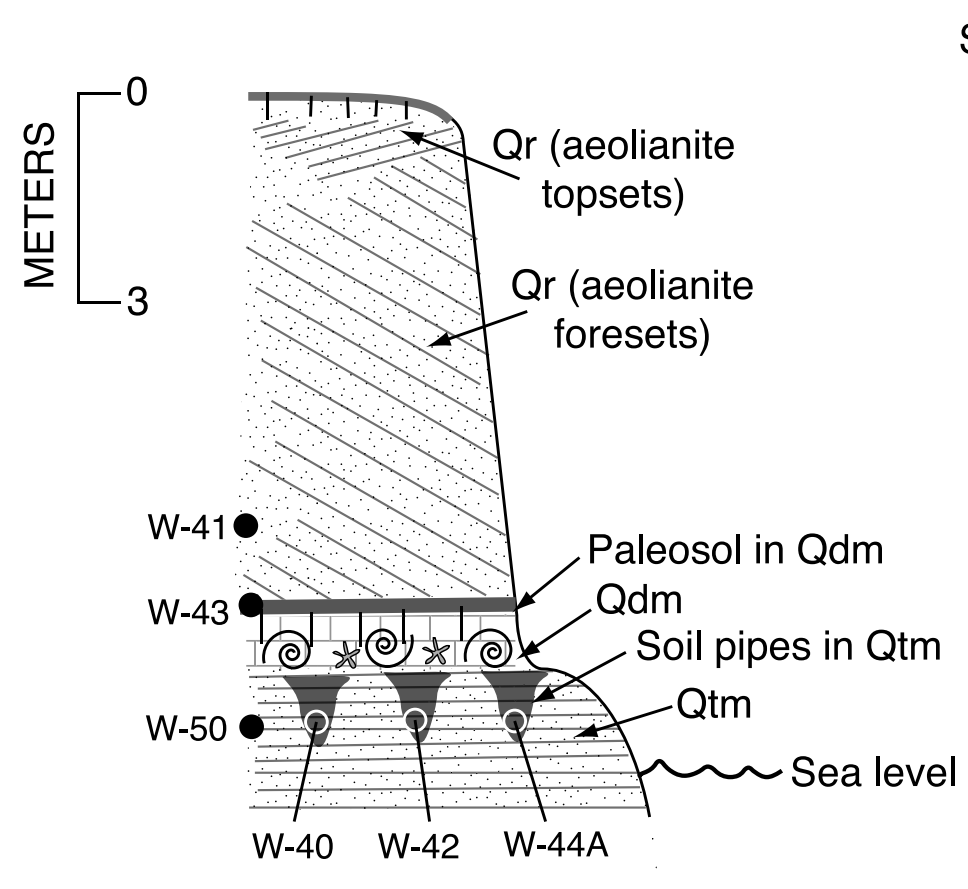

At nearby exposure: W-45, W-52
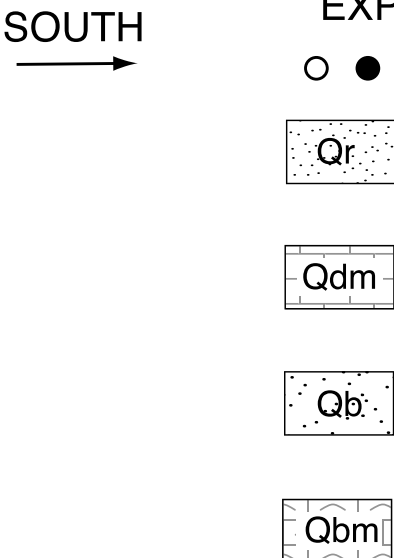

Belmont Formation (marine, $200 \mathrm{ka}$ )

Qtm

Town Hill Formation (marine, $\sim 325 \mathrm{ka}[?]$ )

\begin{tabular}{l|l|l}
\hline & & Soil or paleosol
\end{tabular}

$\int$ Soil pipes

(อ) Marine fossils

次 Corals

Figure 11. Stratigraphy and sampling points for the (a) Coney Island and (b) Whalebone Bay localities. Stratigraphy of Whalebone Bay area from Herwitz and Muhs [1995].

Concentrations of $\mathrm{Fe}_{2} \mathrm{O}_{3}, \mathrm{MgO}$ and $\mathrm{CaO}$ are all lower in these deep samples compared to the shallow samples.

[24] Studies of African dust collected on Barbados by Delany et al. [1967] and Glaccum and Prospero [1980] have shown that quartz is the most important mineral in the silt-sized fraction and mica dominates the clay-sized fraction. Kaolinite, chlorite, microcline, plagioclase, calcite and gypsum are also present in smaller quantities. African dust samples collected on Sal Island (Cape Verde), Barbados, and Florida all have a similar clay mineral composition [Glaccum and Prospero, 1980]. Because of the similarity in clay mineralogy of dust collected on the widely separated localities of Sal Island, 
(a) Grape Bay railroad cut (GRR series):

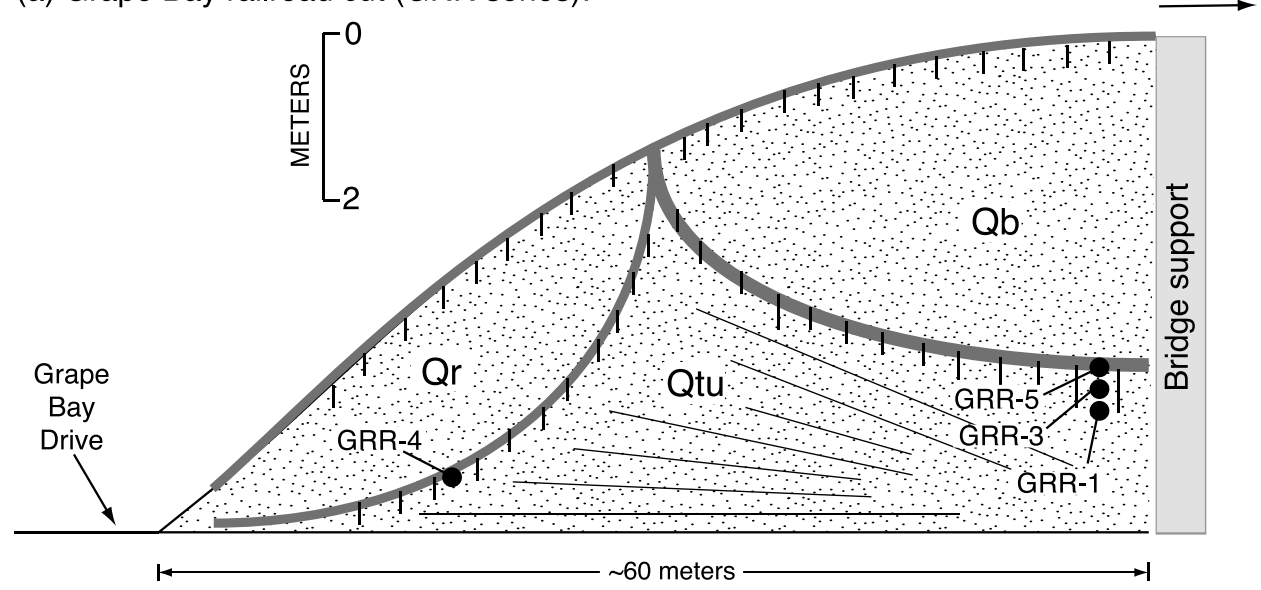

EXPLANATION

- Sample

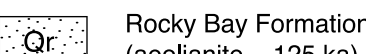

(aeolianite, $\sim 125 \mathrm{ka}$ )

$\mathrm{Qb} \quad$ Belmont Formation

(Aeolianite, $\sim 200 \mathrm{ka}$ )

Town Hill Formation, upper member

(aeolianite, 325 [?] ka)

(b) Ireland Island North construction site (IRE series):

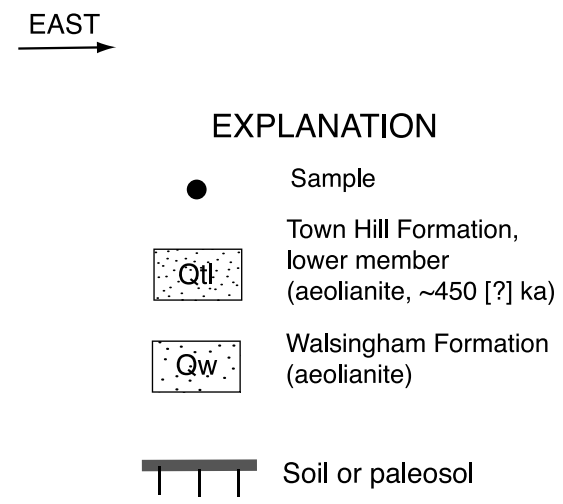

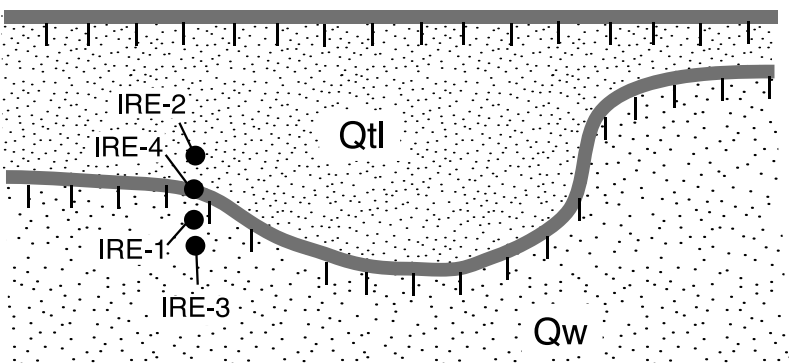

1

Floor of construction site (in 1991)

Figure 12. Stratigraphy and sampling points for the (a) Grape Bay railroad cut and (b) Ireland Island-North localities.

Barbados and Florida, we infer that any African dust reaching Bermuda likely would have a similar composition.

[25] Bulk mineralogy of lower Mississippi River valley loess, derived from a wide variety of rock types traversed by the Laurentide ice sheet, reflects the varying contributions of Precambrian crystalline rocks, Paleozoic carbonate rocks, and Mesozoic shales. Snowden and Priddy [1968] and Pye and Johnson [1988] reported the presence of quartz, K-feldspar, plagioclase, dolomite, calcite and small amounts of heavy minerals in bulk analyses of lower Mississippi River valley loess. Clay minerals include mica, smectite and kaolinite. These mineralogical compositions are consistent with major element geochemistry of the loess reported by Pye and Johnson [1988] and Muhs et al. [2001].

\subsection{Mineralogy of Bermuda Soils and Paleosols}

[26] We conducted mineralogical analyses of both bulk samples and clay separates from Bermuda soils and paleosols. As noted earlier, despite the striking red or reddish-brown colors of Bermuda's terra rossa soils and paleosols, the main non-clay-sized minerals are carbonates. Bulk XRD analyses show that all but one sample contain calcite and in many soils, calcite is the main mineral detected. Approximately two-thirds of the soils also contain aragonite and about a half-dozen contain high-Mg calcite. Although low-Mg calcite can be of secondary origin, either from pedogenesis or diagenesis, both aragonite and high- $\mathrm{Mg}$ calcite are likely detrital remnants of the host carbonate aeolianite. The carbonates in Bermuda aeolianites are derived largely from sand-sized fragments of skeletal materials from marine organisms, including mollusks, corals and Halimeda [Land et al., 1967]. The high abundance of aeolianite-derived carbonate minerals in these paleosols is apparent from the bulk $\mathrm{CaO}$ content, which ranges from $\sim 10 \%$ to almost $60 \%$, and the $\mathrm{Sr}$ content, which ranges from $\sim 600$ to over $6000 \mathrm{ppm}$ (Figure 13). Unlike secondary carbonates or old limestones, $\mathrm{Sr}$ is high in the primary marine carbonate minerals, aragonite and high-Mg calcite, that comprise the skeletons of marine invertebrates. About half the soils also have quartz and a half-dozen have detectable amounts of woodhouseite $\left[\mathrm{CaAl}_{3}\left(\mathrm{PO}_{4}\right)\left(\mathrm{SO}_{4}\right)(\mathrm{OH})_{6}\right]$ or possibly crandallite $\left[\mathrm{CaAl}_{3}\left(\mathrm{PO}_{4}\right)_{2}(\mathrm{OH})_{5} \cdot \mathrm{H}_{2} \mathrm{O}\right]$, both APS (aluminumphosphate/aluminum-sulphate) minerals [Dill, 2001, 2010]. A few soils contain halite and gypsum, which we interpret to be derived from marine aerosols. Heavy minerals, if present, are in abundances too low to be detected by XRD. As 

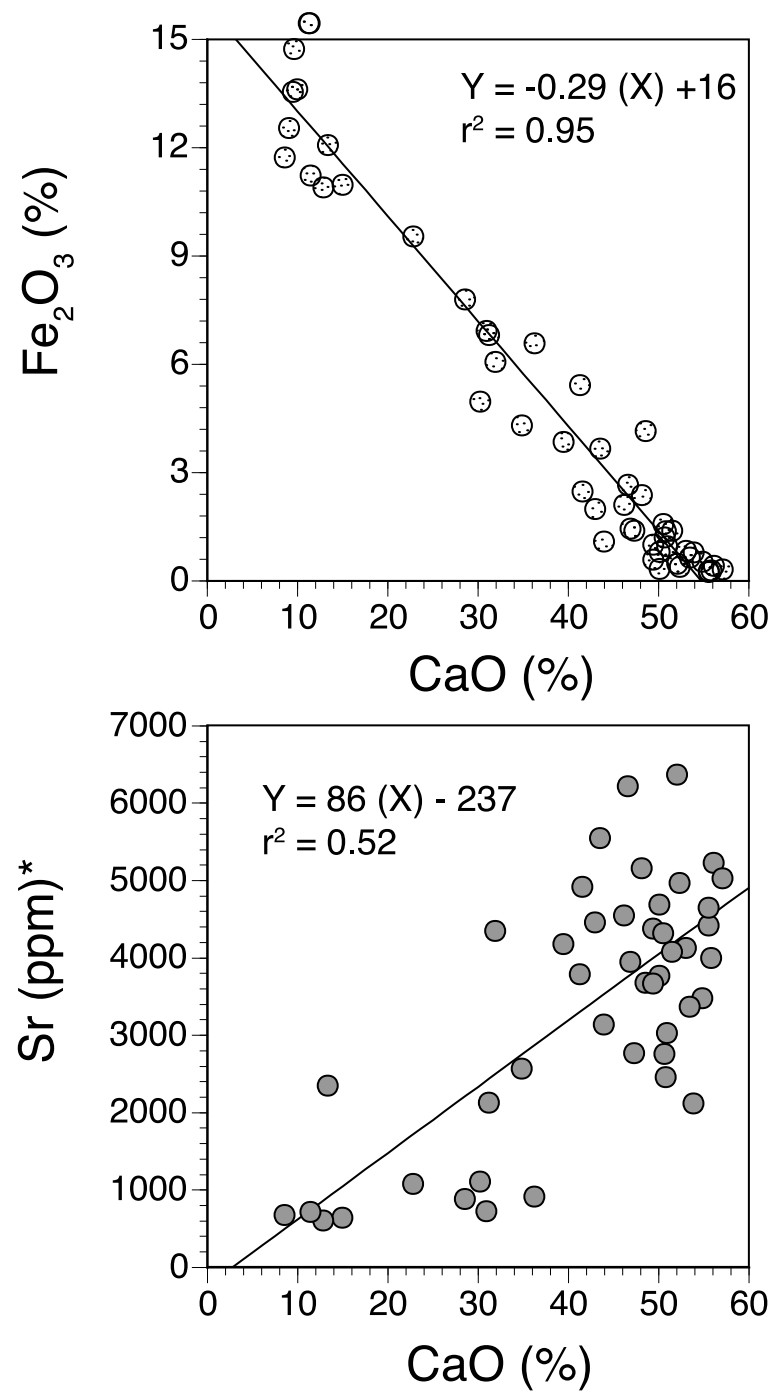

*[does not include 6 very high $\mathrm{Sr}$, low $\mathrm{CaO}$ samples that do not contain aragonite or high-Mg calcite]

Figure 13. (top) Plot showing inverse relation between $\mathrm{Fe}_{2} \mathrm{O}_{3}$ content (representing clay mineral abundances) and $\mathrm{CaO}$ content (representing carbonate mineral content). (bottom) Plot showing positive relation between $\mathrm{CaO}$ and $\mathrm{Sr}$ contents (note that some samples not shown).

discussed earlier, the non-carbonate fractions of Bermuda soils and paleosols are composed largely of clay minerals. Thus, bulk $\mathrm{CaO}$ content is inversely proportional to claydominated major elements such as $\mathrm{Fe}_{2} \mathrm{O}_{3}$ (Figure 13).

[27] The clay mineralogy of Bermuda soils is similar in all soils we studied, regardless of age, with only a few exceptions. Our analyses include paleosols on five ages of aeolianite (Figures 7-12), including one of the youngest, the Rocky Bay Formation of last interglacial $(\sim 120 \mathrm{ka})$ age, as well as the oldest, the Walsingham Formation (>900 ka). In all soils, the dominant clay mineral is a mixed-layer species that has, when X-rayed in an air-dry condition, prominent peaks at d-spacings of $14.2 \AA, 7.1 \AA, 4.8 \AA$, and $3.56 \AA$ (Figure 14). These peaks are unaffected by glycolation. However, the $14.2 \AA$ peak collapses to about $12.5 \AA-12.6 \AA$ when heated $\left(550^{\circ} \mathrm{C}\right)$ and the other peaks either disappear (in most cases) or diminish to very low intensities (in a few cases). Ruhe et al. [1961] interpreted XRD data they acquired from Bermuda paleosols to indicate the presence of vermiculite in many samples. We tested this hypothesis with K-saturation of the clays, but this treatment left the $14.2 \AA, 7.1 \AA$, $4.8 \AA$, and $3.56 \AA$ unaffected (Figure 14). Thus, we do not consider the patterns in our analyses to represent vermiculite. Based on diagnostic criteria given by Barnhisel and Bertsch [1989] and Foos and Bain [1995], we interpret the dominant clay mineral in Bermuda soils and paleosols to be hydroxy-interlayered clay (HIC). HIC spans a wide range of compositions, with endmembers including relatively pure smectite or vermiculite at one extreme and Al-rich chlorite at the other extreme [Barnhisel and Bertsch, 1989]. HIC is common in many soils and has been reported in soils on carbonate aeolianite on Eleuthera in the Bahamas [Foos and Bain, 1995]. We have also observed it in modern soils on $\sim 120$ ka carbonate beach deposits on New Providence Island in the Bahamas and in modern soils on $\sim 120 \mathrm{ka}$ coral reef deposits on Key Largo, Florida (Figure 15). Prognon et al. [2011], who also studied the clay mineralogy of Bermuda paleosols, reported XRD patterns that are very similar to ours. However, they rejected an HIC identification of the Bermuda soil clays and interpreted their XRD patterns to indicate a mixed-layer chlorite-vermiculite. Their interpretation is based on a shift of the $14.2 \AA$ peak to $12.5 \AA$, rather than $10 \AA$, with heat treatment $\left(550^{\circ} \mathrm{C}\right)$. Foos and Bain [1995] pointed out, however, that heat treatment of HIC can shift the $14.2 \AA$ peak to either $12.5 \AA$ or, with low levels of interlayering, to $10 \AA$.

[28] Other minerals in the clay fraction of Bermuda soils include an APS species (probably woodhouseite), boehmite, goethite and quartz. Ruhe et al. [1961] and Prognon et al. [2011] also identified a phosphate mineral in Bermuda soils that they considered to be crandallite. High-angle XRD peaks of both woodhouseite and crandallite are similar $(2.93 \AA$ and $2.163 \AA$ ), but woodhouseite has a prominent peak at $4.85 \AA$ whereas crandallite does not [Anthony et al., 2000]. All the soils we examined that have a phosphate mineral have a prominent peak at $4.85 \AA$, on the low-angle side of the thirdorder HIC peak (Figure 14). Thus, we interpret the phosphate mineral in Bermuda soils to be woodhouseite.

[29] Some soils contain boehmite, an Al-rich clay mineral. Boehmite is identifiable by a distinct peak at $6.1 \AA$ that is unaffected by glycolation or K-saturation, but with heat treatment $\left(550^{\circ} \mathrm{C}\right)$, it collapses. We found boehmite in both the A and $\mathrm{B}$ horizons of the paleosol developed on aeolianite of the Walsingham Formation at Ireland Island-North (Figure 14). Boehmite is also present in the surface soil developed on a lastinterglacial-age reef on Key Largo, Florida (Figure 15) and Foos and Bain [1995] reported boehmite in a soil developed on carbonate aeolianite on Eleuthera Island, Bahamas. Goethite was found in a number of paleosols, as was clay-sized quartz, but where they occur, abundances of both of these minerals are much lower than the amounts of clay-sized HIC, woodhouseite or boehmite, based on relative peak heights.

\section{Trace Element Geochemistry}

\subsection{Overall Measures of REE and Other Trace Elements}

[30] One of the most commonly used approaches in using trace element geochemistry for provenance studies is to plot 
(a) Vesey Street section: A horizon on Qr eolianite

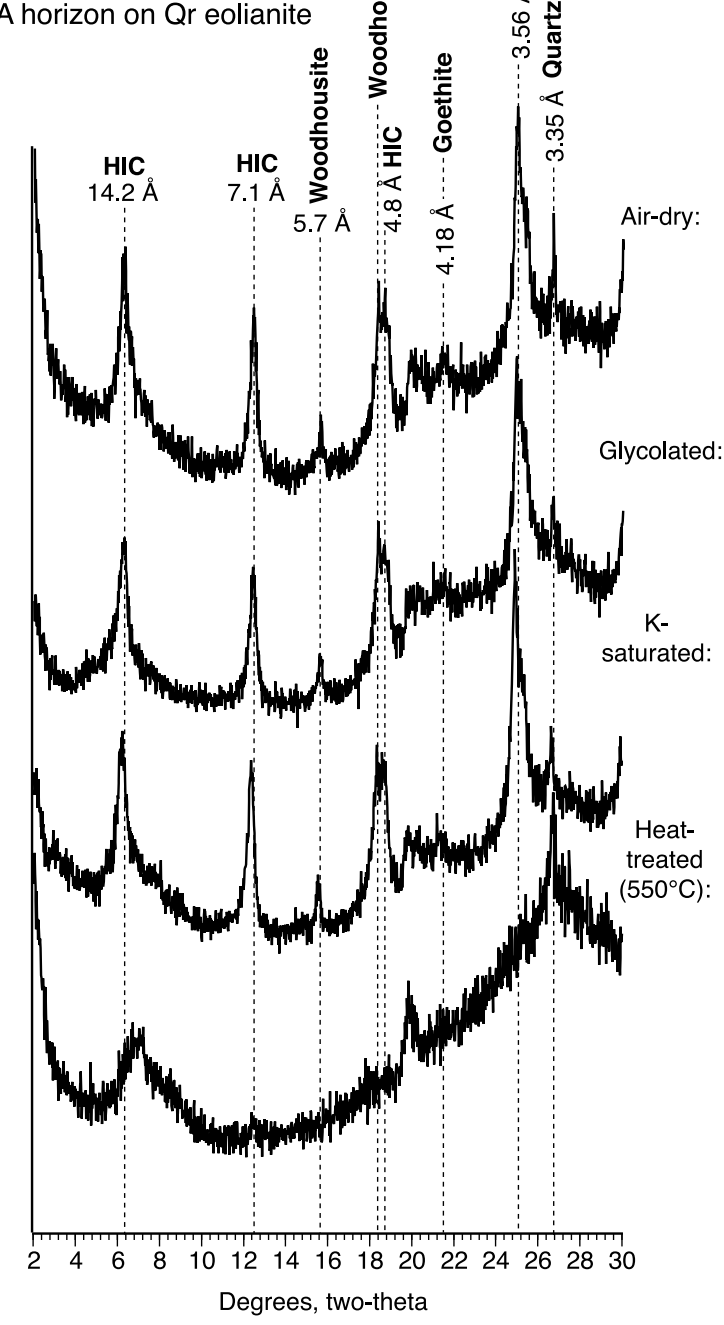

(b) Other localities:

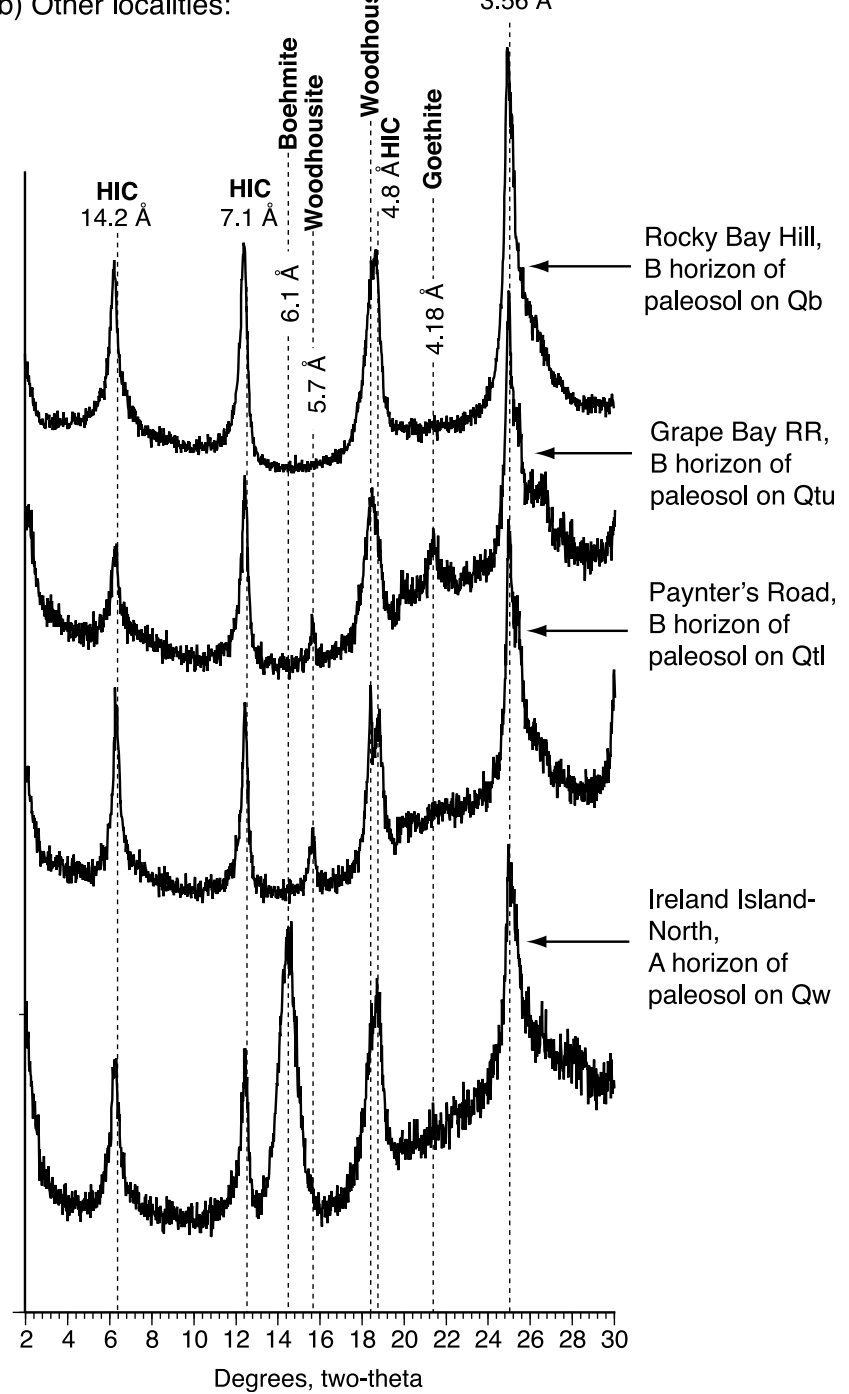

Figure 14. (a) X-ray diffractogram of the $<2 \mu \mathrm{m}$ fraction in the A horizon of the modern soil at the Vesey Road locality, showing changes in peak positions with different treatments. (b) X-ray diffractograms of clay minerals (all glycolated) for paleosols from four localities on Bermuda.

concentrations of three geochemically distinct elements in ternary diagrams. An example is the relative abundance of Sc, Th, and La [Taylor and McLennan, 1985; Olivarez et al., 1991; Muhs et al., 2007a, 2007b, 2008, 2010b]. On a Sc-ThLa plot, oceanic basalts, or sediments derived from them, will plot near the Sc pole, whereas average upper continental crustal rocks, or sediments derived from them, will plot near the La pole. Ternary plots of Sc-Th-Ta, Cr-Th-Nd, Cr-Ta$\mathrm{Nd}$, and Cr-Hf-Th plots also can be effective discriminators between oceanic volcanic rocks and upper continental crustderived sediments [Muhs et al., 2008, 2010b].

[31] For REE, certain parameters have been developed that reduce concentration data and facilitate comparisons in provenance studies. Plots of $\mathrm{Eu} / \mathrm{Eu}^{*}$ versus $\mathrm{La}_{\mathrm{N}} / \mathrm{Yb}_{\mathrm{N}}$ and $\mathrm{Eu} /$ $\mathrm{Eu}^{*}$ versus $\mathrm{Gd}_{\mathrm{N}} / \mathrm{Yb}_{\mathrm{N}}$ provide the potential for defining REE compositional fields that are distinctive for the various soil parent materials. This approach has been used by many investigators studying the provenance of aeolian sediments or even the origin of upper continental crust in general [McLennan, 1989; Taylor and McLennan, 1985, 1995; Nakai et al., 1993; Gallet et al., 1996; Jahn et al., 2001; Sun, 2002; Muhs and Budahn, 2006; Muhs et al., 2007a, 2010b].

\subsection{Trace Element Composition of Bermuda Soils and Paleosols Compared to Potential Parent Materials}

[32] In this study, we utilize Sc-Th-La and Cr-Ta-Nd plots to discriminate the possible parent materials for Bermuda's soils and paleosols. Consistent with its mineralogy and major element geochemistry discussed above, deeper $(60$ $61 \mathrm{~m}$ ) volcanic rocks on Bermuda plot near the Sc pole on a Sc-Th-La diagram, similar to what is reported for typical oceanic basalts (Figure 16a). On the other hand, shallow (39-57 m) volcanic rocks on Bermuda, which are the most likely to have influenced the soils on the island, plot much closer to what is typical for upper continental crust, but again consistent with the unusual mineralogy of these rocks. 


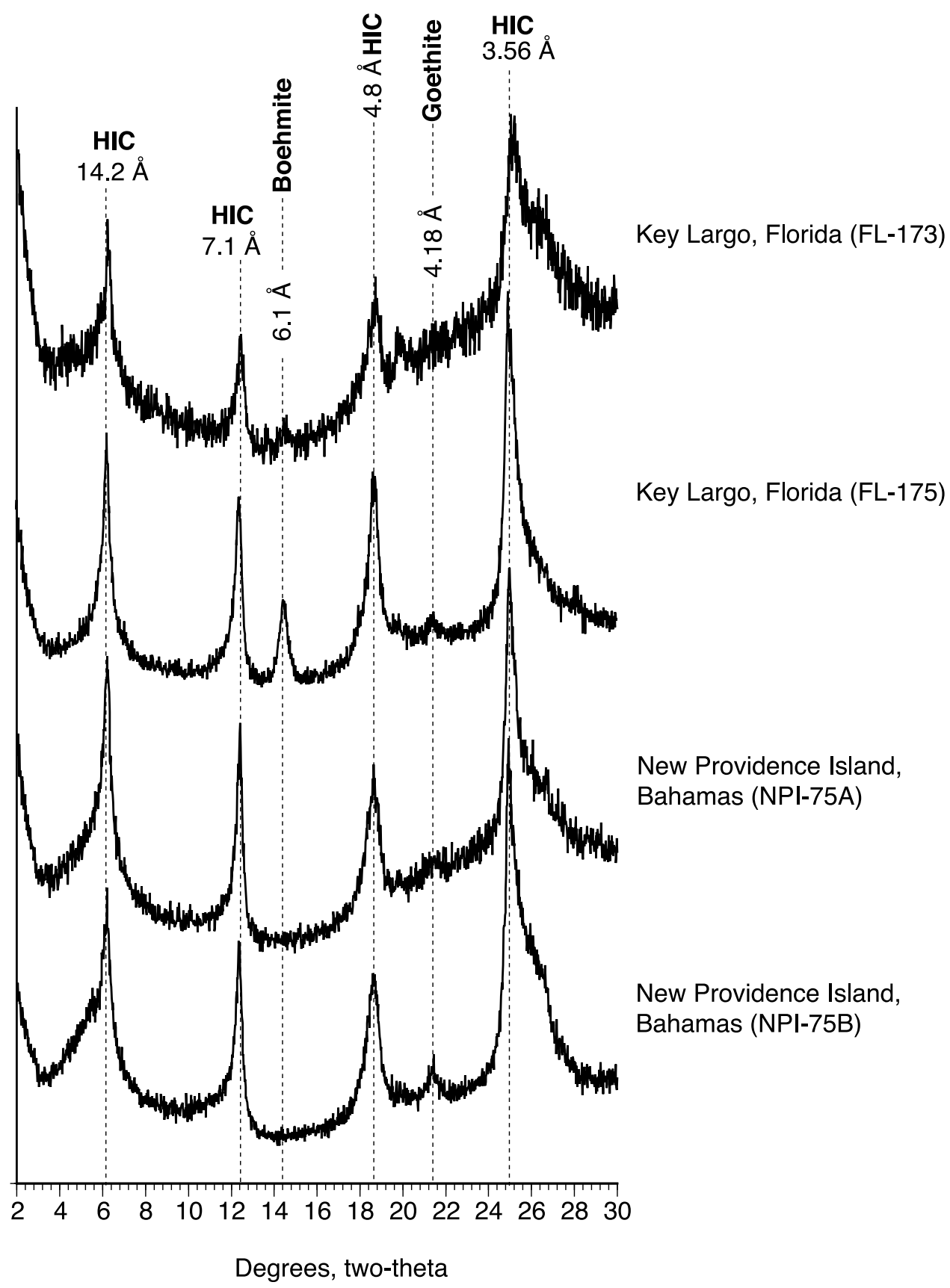

Figure 15. X-ray diffractograms of the $<2 \mu \mathrm{m}$ fraction for four soils on last-interglacial-age (120 ka) carbonate rocks on Key Largo, Florida and New Providence Island, Bahamas.

This is unfortunate, as it does not allow for as simple a process of parent material discrimination as we would prefer. Nevertheless, on a Sc-Th-La plot, the field occupied by shallow volcanic rocks on Bermuda does not overlap the fields of African dust collected on Barbados or Bermuda. The two African dust fields are similar compositionally, but do not overlap completely. Mississippi River valley loess cannot be distinguished from African dust collected on Barbados. Because of the similarity in Sc-Th-La composition between the competing parent materials, we enlarged a portion of the ternary plot in order to illustrate more clearly the intermediate composition of most Bermuda soils and paleosols
(Figure 16c). Bermuda soils and paleosols from most localities (excluding Whalebone Bay) have Sc-Th-La compositions that fall between the volcanic and African dust/Mississippi loess fields. At Whalebone Bay, soil pipes developed in the upper member of the Town Hill Formation and the horizontal paleosol remnants developed on the Devonshire Member of the Rocky Bay Formation (Figure 11) have Sc-Th-La compositions that do not fall neatly into any field for the various parent materials (Figure 16b). The samples from Whalebone Bay fall closest to the field for the shallow Bermuda volcanic rocks, but are more depleted in $\mathrm{Sc}$ and more enriched in $\mathrm{La}$ compared to these materials. 


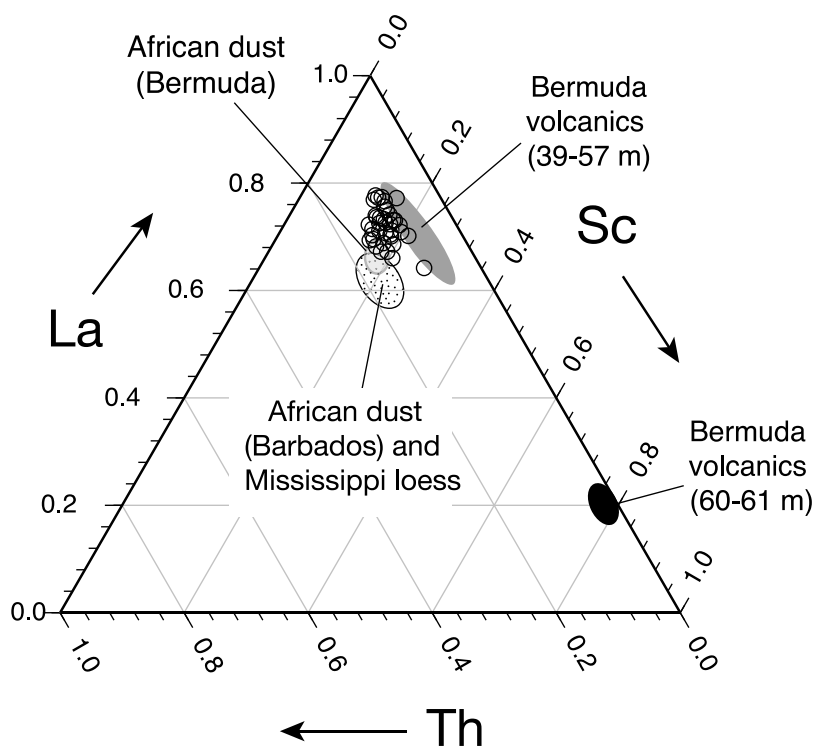

(a) Bermuda soils outside of Whalebone Bay

(c) Bermuda soils outside of Whalebone Bay (enlarged)

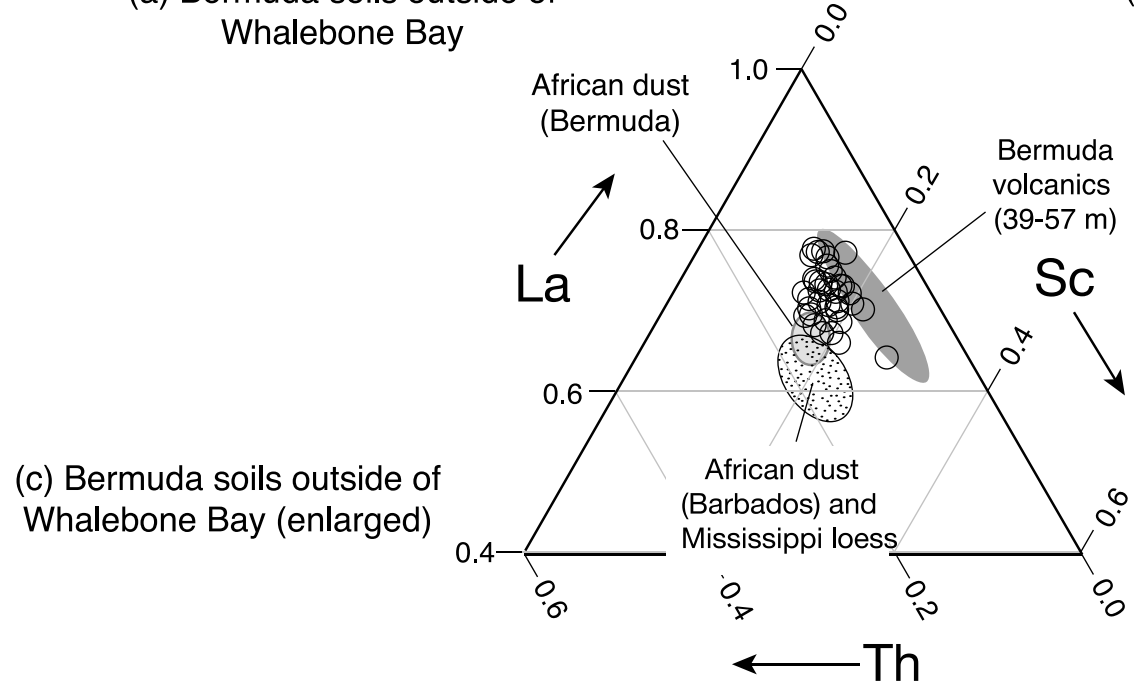

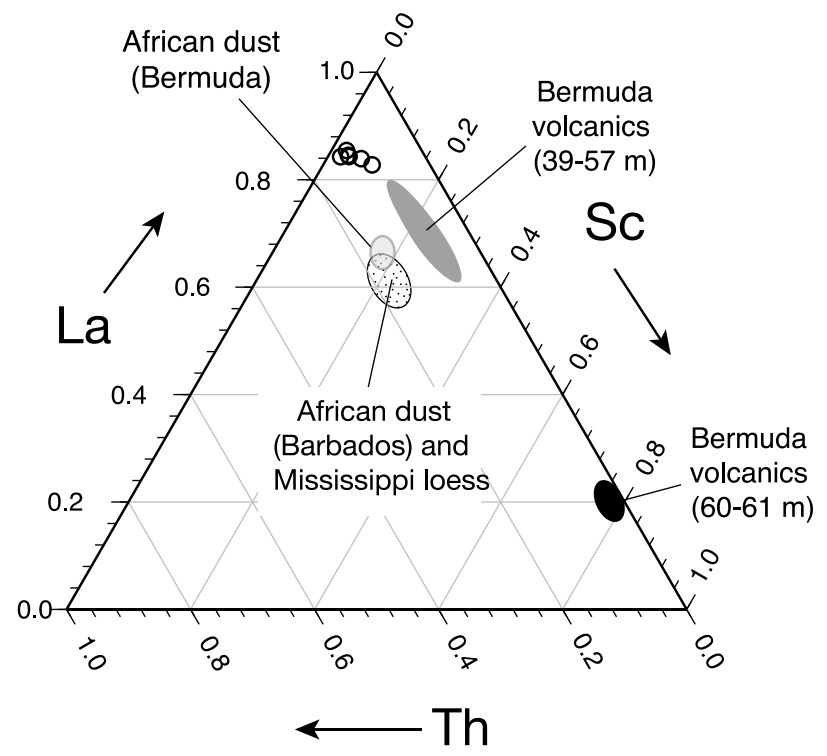

(b) Bermuda soils at Whalebone Bay

Figure 16. Sc-Th-La ternary diagrams of (a) soils outside of Whalebone Bay on Bermuda (circles) and (b) soils at Whalebone Bay (circles), compared to the compositions of Bermuda volcanic rocks, African dust collected on Barbados and Mississippi loess [Muhs et al., 2007a], and African dust collected on Bermuda (this study). (c) Enlargement of a portion of diagram shown in (a).

[33] For Cr-Ta-Nd (plotted as $\mathrm{Cr} / 10-\mathrm{Th} \times 10-\mathrm{Nd}$ for clarity), upper and lower volcanic rocks on Bermuda are distinctly different from all aeolian sources (Figure 17). African dust collected on Barbados and Bermuda cannot be differentiated from each other and are plotted together. Mississippi River Valley loess overlaps African dust only partially and is plotted separately. Of those Bermudan soils and paleosols outside of Whalebone Bay, two fall close to, but not on the field for shallow volcanic rocks. Four more fall close to the field for African dust. All the others plot well away from the fields for volcanic rocks, but close to the African dust and Mississippi loess fields. For the paleosols at Whalebone Bay, all samples fall within or very close to the field for shallow volcanic rocks.

[34] Chondrite-normalized plots of REE abundances illustrate the differences in composition between Bermuda volcanic rocks, Mississippi River valley loess, and African dust
(Figure 18). Deep volcanic rocks on Bermuda show no significant enrichment of the light REE relative to the heavy REE. Such a pattern is quite typical for oceanic basalts and is consistent with the other compositional data (both mineralogical and geochemical) for these rocks. On the other hand, shallow volcanic rocks on Bermuda show a significant enrichment in the light REE. Neither group of volcanic rocks, however, displays a negative $\mathrm{Eu}$ anomaly. The volcanic-grain-rich beach sand (sample W-50) we collected from the upper member of the Town Hill Formation at Whalebone Bay shows a REE composition similar to that for the shallow volcanic rocks on Bermuda, with enriched light REE. For African dust, we present three REE plots, for different size fractions, from dust samples collected on Barbados on 14 June 1967 (data originally reported by Muhs et al. [2010b]). These samples show a typical upper continental crustal pattern with enriched 
(a) Bermuda soils outside of Whalebone Bay

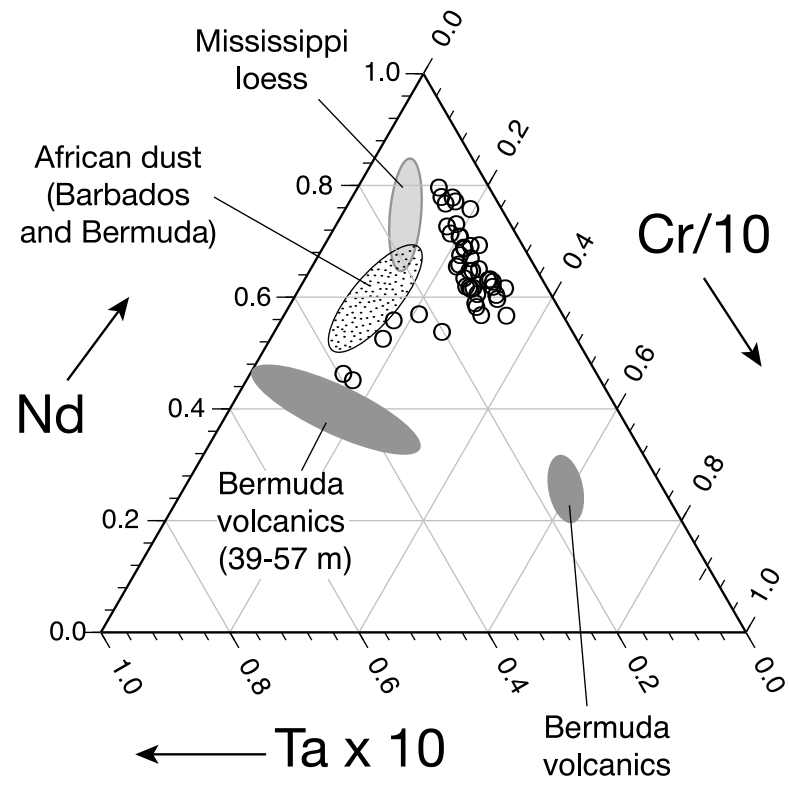

$(60-61 \mathrm{~m})$

\section{(b) Bermuda soils at Whalebone Bay}

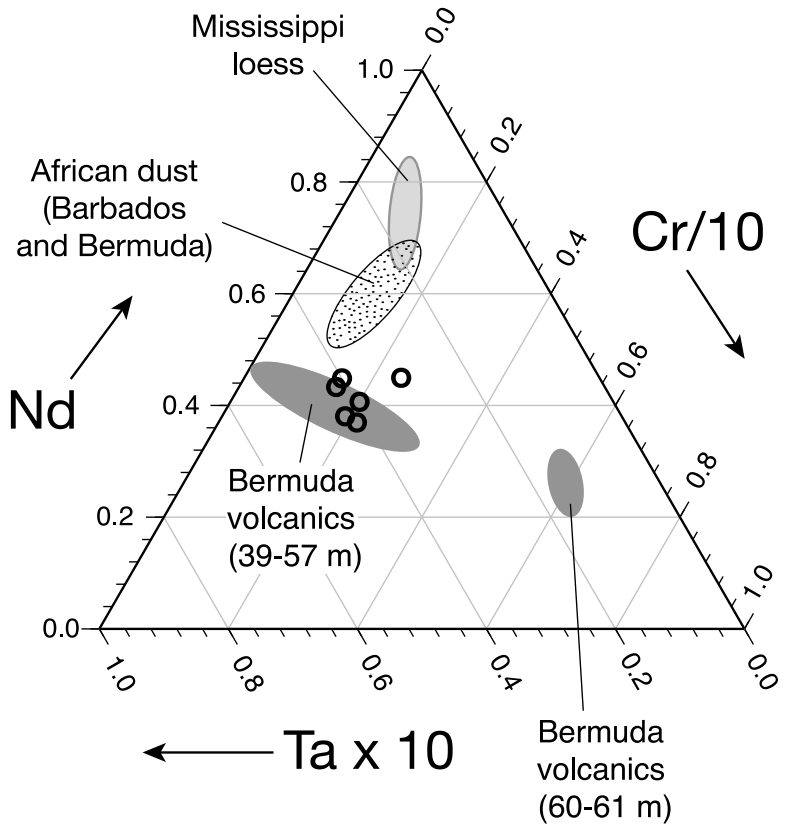

Figure 17. $\mathrm{Cr} / 10-\mathrm{Ta} \times 10-\mathrm{Nd}$ ternary diagrams of (a) soils outside of Whalebone Bay on Bermuda (circles) and (b) soils at Whalebone Bay (circles), compared to the compositions of Bermuda volcanic rocks, African dust collected on Barbados and Bermuda [Muhs et al., 2007a; this study], and Mississippi loess [Muhs et al., 2007a].

light REE, a negative Eu anomaly, and depleted heavy REE. For the light and middle REE, abundances are greater in the clay $(<2 \mu \mathrm{m})$ fraction than they are in the fine silt $(2-5 \mu \mathrm{m}$ and 5-10 $\mu \mathrm{m})$ fractions. Mississippi River valley loess shows similar REE patterns to African dust and the reader is referred to Muhs et al. [2007a] for diagrams illustrating this.

[35] The majority of soils and paleosols on Bermuda, outside of Whalebone Bay, have REE curves that are closer to those of African dust or Mississippi River valley loess than to Bermuda volcanic rocks. All have relatively enriched LREE (except for $\mathrm{Ce}$ ) and a negative $\mathrm{Eu}$ anomaly. One difference is that all of the Bermuda soils and paleosols shown in Figure 18 have negative Ce anomalies. We have observed negative Ce anomalies in higher-elevation (older) soils on Barbados, but have not observed it in lower-elevation (younger) soils on Barbados, or in soils on the Bahamas or Florida Keys [Muhs et al., 2007a]. The cause of the negative Ce anomalies is not understood, but could be due to a timerelated weathering process in soils, a subject beyond the scope of the present study. In addition, we note that all soils outside of Whalebone Bay have slightly depleted LREE and slightly enriched HREE when compared to unaltered African dust or Mississippi River valley loess. We observed this characteristic in older Barbados soils as well [Muhs et al., 2007a]. Thus, while Bermuda soils outside Whalebone Bay have a REE pattern that is broadly similar to unaltered African dust or Mississippi River valley loess, depletion of LREE (especially $\mathrm{Ce}$ ) and enrichment of HREE appear to be time-dependent pedogenic processes that occur in soils of both Bermuda and Barbados. Some Bermuda soils appear to have aspects of both the "evolved" REE signature and a relatively unaltered African dust or Mississippi River valley loess-type of REE pattern. In contrast, most of the paleosols at Whalebone Bay display REE patterns that resemble those of the shallow volcanic rocks on Bermuda.

[36] Plots of $\mathrm{Eu} / \mathrm{Eu}^{*}$ versus $\mathrm{La}_{\mathrm{N}} / \mathrm{Yb}_{\mathrm{N}}$ and $\mathrm{Eu} / \mathrm{Eu}^{*}$ versus $\mathrm{Gd}_{\mathrm{N}} / \mathrm{Yb}_{\mathrm{N}}$ provide easy discrimination of the volcanic rocks on Bermuda and the dust sources. Enrichment of both the light and middle REE makes a very clear separation of the shallow volcanic rocks from all other possible parent materials, including the deeper volcanic rocks (Figure 19). Negative $\mathrm{Eu}$ anomalies distinguish the dust sources from both volcanic sources. There is considerable overlap between all three suites of LRT dust samples in the fields defined by Eu/ $\mathrm{Eu}^{*}$ versus $\mathrm{La}_{\mathrm{N}} / \mathrm{Yb}_{\mathrm{N}}$ and $\mathrm{Eu} / \mathrm{Eu}^{*}$ versus $\mathrm{Gd}_{\mathrm{N}} / \mathrm{Yb}_{\mathrm{N}}$, and we do not consider the differences to be particularly significant. What apparent differences exist are probably to some extent a function of sample size, with African dust from Barbados, our largest data set, showing the largest compositional range.

[37] Most Bermuda soils and paleosols (outside of Whalebone Bay) have $\mathrm{Eu} / \mathrm{Eu}{ }^{*}$ versus $\mathrm{La}_{\mathrm{N}} / \mathrm{Yb}_{\mathrm{N}}$ and $\mathrm{Eu} / \mathrm{Eu}^{*}$ versus $\mathrm{Gd}_{\mathrm{N}} / \mathrm{Yb}_{\mathrm{N}}$ values that fall within, or close to the field defined by African dust from Barbados. As noted above, many Bermuda soils have slight depletions of LREE and slight enrichments of heavy REE compared to dust samples. This is reflected in soil $\mathrm{La}_{\mathrm{N}} / \mathrm{Yb}_{\mathrm{N}}$ values that are below, or in 

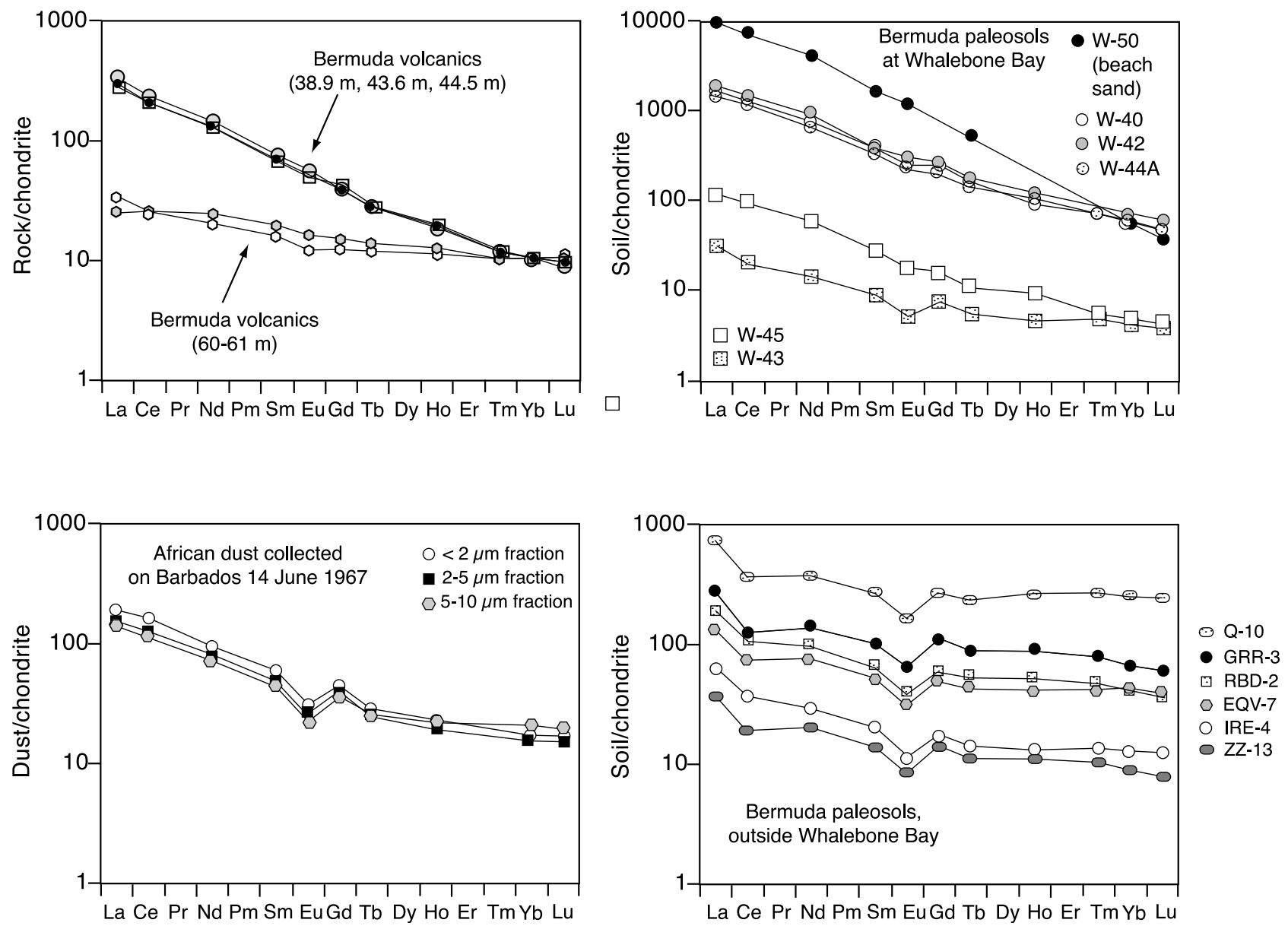

Figure 18. Chondrite normalized plots of rare earth element abundances for Bermuda volcanic rocks, African dust collected on Barbados [Muhs et al., 2010b], and Bermuda soils, outside of Whalebone Bay and at Whalebone Bay.

the lower range of $\mathrm{La}_{\mathrm{N}} / \mathrm{Yb}_{\mathrm{N}}$ values found in the dust samples. Only one sample falls within the field for Mississippi River loess and only four samples plot close to the field for African dust collected on Bermuda. Nevertheless, there is no evidence in the $\mathrm{Eu} / \mathrm{Eu}^{*}$ versus $\mathrm{La}_{\mathrm{N}} / \mathrm{Yb}_{\mathrm{N}}$ and $\mathrm{Eu} / \mathrm{Eu}^{*}$ versus $\mathrm{Gd}_{\mathrm{N}} / \mathrm{Yb}_{\mathrm{N}}$ plots for a significant volcanic component to the soils and paleosols outside of Whalebone Bay. In contrast, four of the soils from Whalebone Bay (the three soil pipes developed in the upper member of the Town Hill Formation and one of the horizontal paleosols developed on the Devonshire marine member of the Rocky Bay Formation) show a very clear, local volcanic influence. These four samples fall in between the shallow volcanic and aeolian fields, but are closer to the field defined by the shallow volcanic rocks. On the other hand, two of the horizontal paleosols developed on the Devonshire marine member of the Rocky Bay Formation at Whalebone Bay fall clearly within the dust fields, indicating little or no influence from the shallow volcanic rocks.

\section{Discussion}

[38] The mineralogy of the soils and paleosols on Bermuda is an uncommon mix of detrital marine carbonates, clay minerals dominated by HIC, quartz and an APS mineral, likely woodhousesite or possibly crandallite. This unusual combination of minerals is due to several processes operating on this island. The carbonate minerals, high-Mg calcite, low-Mg calcite and aragonite, are very likely detrital grains from the host aeolianites that dominate the island. It is interesting that even within the B horizons of soils or paleosols that are reddish-brown, clay-rich and morphologically well developed, we found significant amounts of detrital aragonite. This observation is surprising, given that mean annual precipitation on Bermuda is $\sim 1400 \mathrm{~mm}$ (1949-1999 records from Bermuda Weather Service: www.weather.bm/ data/climatology) and precipitation is fairly evenly distributed through the year. Thus, we would not expect carbonate minerals, calcite and aragonite, to survive in the upper horizons of soils under such a precipitation regime. An explanation offered by previous authors is that sand-sized carbonate particles were deposited by wind to soils that were still in the process of formation when a new, late-interglacial phase of carbonate-rich dune formation began. Yet another possibility is that bioturbation has been active on Bermuda, which could result in mechanical mixing of detrital carbonates from an aeolianite into an overlying soil (see Hole [1981] and Johnson et al. [2005] for reviews of bioturbation in soils). 

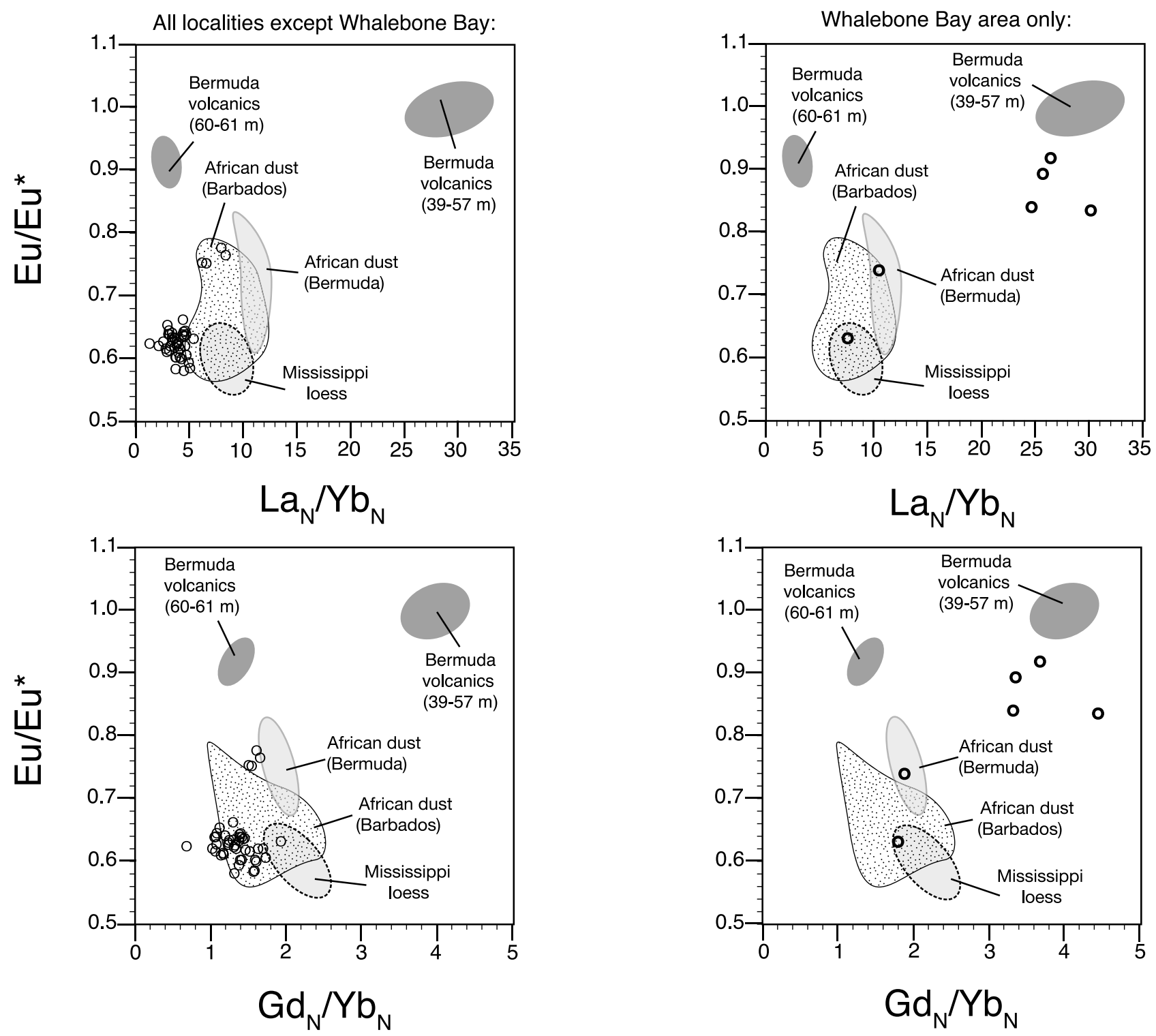

Figure 19. Plots of $\mathrm{Eu} / \mathrm{Eu}^{*}$ versus $\mathrm{La}_{\mathrm{N}} / \mathrm{Yb}_{\mathrm{N}}$ and $\mathrm{Eu} / \mathrm{Eu}^{*}$ versus $\mathrm{Gd}_{\mathrm{N}} / \mathrm{Yb}_{\mathrm{N}}$ for Bermuda volcanic rocks, African dust, Mississippi loess, and Bermuda soils, outside of Whalebone Bay and at Whalebone Bay.

Although Bermuda has a very limited native land fauna (and hence few burrowing animals of any kind, whether native or exotic), it does have a number of species of ants, some of which could be natives [Wetterer and Wetterer, 2004]. If so, then bioturbation by ants in Bermudan soils is a possibility, even prior to European arrival.

[39] The dominant clay mineral in soils and paleosols of all ages is hydroxy-interlayered clay (HIC), as determined by a four-treatment XRD process. The presence of HIC as the main clay mineral in Bermuda's soils and paleosols is consistent with similar observations of HIC we have made for soils on carbonate beach deposits in the Bahamas and in soils on Quaternary carbonate reefs in the Florida Keys. Foos and Bain [1995] also reported HIC in soils on carbonate aeolianites in the Bahamas. As discussed earlier, Prognon et al. [2011] presented X-ray diffractograms for soil clay minerals in Bermuda very similar to our own, although they interpret these patterns to represent randomly interlayered vermiculitechlorite. The issue of "vermiculite-chlorite" versus "HIC" is somewhat semantic, however, as Foos and Bain [1995] pointed out that mixed-layer vermiculite-chlorite is a term that has been applied to HIC in the past. Furthermore, Barnhisel and Bertsch [1989] stated that HIC has a wide range of compositions, with pure smectite or vermiculite as one end-member and pure chlorite as the other. Prognon et al. [2011] pointed out correctly that illite/mica is the major component in African dust, as reported by Delany et al. [1967] and Glaccum and Prospero [1980]. A lack of detectable mica in Bermuda soils led Prognon et al. [2011] to conclude that an LRT dust component cannot be detected and further that the chlorite-bearing minerals must be derived from weathering of volcanic grains. This line of reasoning assumes that mica derived from LRT dust is stable in soils after deposition and that chlorite and/or chlorite/vermiculite 
are derived primarily from weathering of volcanic grains. On Bermuda, there are several possible precursors to the HIC we observe in the soils and paleosols. Chlorite is present in both the volcanic bedrock on the island, based on our own analyses reported here, and is also present in African dust, based on data in Glaccum and Prospero [1980]. Thus, some of the chlorite components of the HIC in Bermuda soils could be in part inherited from either local sources or African dust. We found mica present in the local volcanic bedrock as phlogopite, a Mg-rich mica that is similar in composition to biotite. Mica, reported as illite by Glaccum and Prospero [1980], is also the most important clay mineral in African dust collected on the Cape Verde Islands, Miami, and Barbados and is one of the most important clay minerals in Mississippi loess. Alteration of mica, particularly mica with a biotite-like structure and chemistry, to vermiculite is a very common process in soils; vermiculite, in turn, can be altered to chlorite or mixed-layer vermiculite-chlorite [Birkeland, 1999]. Thus, mica and chlorite can originate from both the local volcanic bedrock on Bermuda and African dust. Alteration of any of these minerals can yield the HIC we observe in Bermuda soils and paleosols.

[40] Finally, we observe $\mathrm{HIC}$ as the main clay mineral in soils on the Florida Keys and the Bahamas, where, in both cases, there is no local volcanic source and where there is abundant evidence of African dust additions every year [Prospero, 1999; Prospero and Nees, 1987; Prospero et al., 1987, 2010]. These soils formed in the past $\sim 120 \mathrm{ka}$ on the Florida Keys, based on U-series dating of corals from the reef limestone that directly underlies the soils [Muhs et al., 2011]. Trace element data presented in an earlier study indicate that African dust is the dominant parent material for soils on both the Florida Keys and Bahamas [Muhs et al., 2007a]. Despite the evidence for mica as an important component of African dust reaching Florida, we did not detect mica in soils of the Florida Keys or the Bahamas. This indicates to us that mica derived from LRT dust is not stable in this soil environment and alters to other forms. Thus, with similar precipitation regimes (Bermuda, $\sim 1400 \mathrm{~mm} / \mathrm{yr}$; New Providence Island, Bahamas, 1300-1400 mm/yr; Key Largo, Florida $~ 1100 \mathrm{~mm} /$ yr) and warm temperatures year-round, there is a favorable climate for mica alteration to HIC on a Quaternary timescale on all three islands. It seems highly unlikely that HIC would form from African dust on two of these islands, but form only from volcanic minerals on a third, when all three have similar climatic regimes.

[41] The origin of quartz on Bermuda has long been debated. Coarse-grained quartz has been observed by a number of previous researchers [Sayles, 1931; Ruhe et al., 1961; Prognon et al., 2011] and we confirmed the presence of quartz in bulk XRD analyses. Sayles [1931] proposed novel modes of origin for the presence of sand-sized quartz on Bermuda, including avian transport, hurricanes, and oceanic transport via sargasso weed. A simpler explanation is that coarse-grained quartz is derived from the local volcanic rocks, which we detected in 5 of the 12 volcanic rock core samples we analyzed. Clay-sized quartz, which we also detected in a number of samples, could be derived either from local volcanic bedrock or from LRT dust.

[42] In an extensive review on the topic, Dill [2001] pointed out that APS minerals such as woodhouseite and crandallite can form under a wide variety of near-surface conditions on the Earth, provided there are no limitations on the supplies of the major elements $\mathrm{Al}, \mathrm{P}$, and $\mathrm{S}$. In addition, both of the APS minerals woodhouseite and crandallite require $\mathrm{Ca}$. Calcium is abundant in the form of the host carbonate aeolianite substrates on Bermuda. Sulfur, as sulfate $\left(\mathrm{SO}_{4}^{-2}\right)$ is available from marine aerosols (atmospheric sea salt) and from gaseous precursors (e.g., oxidation of dimethylsulfide emitted from the ocean [Savoie et al., 2002]). We have already noted the presence of gypsum in Bermuda soils, which likely derived sulfate from these same sources. Aluminum is readily available in clay minerals of Bermuda soils.

[43] The remaining ingredient for APS minerals is phosphorus. Dill [2001] discussed sources of P from host rocks in a variety of igneous, sedimentary and metamorphic rock settings, none of which apply to Bermuda. Prognon et al. [2011] thought that $P$ on Bermuda was supplied from apatite in the volcanic rocks. We did not detect apatite by XRD in the volcanic rocks from Bermuda we analyzed, but its presence is likely, based on our XRF analyses, which indicate $\mathrm{P}_{2} \mathrm{O}_{5}$ contents of $0.71-1.22 \%$. Talbot et al. [1986] reported that African dust has fairly low concentrations of water-soluble $\mathrm{P}$ (reported as $\mathrm{PO}_{4}$ ), averaging about $0.037 \%$ $(n=6)$. We know of no data on water-insoluble P contents of African dust from Western Hemisphere collections. Nevertheless, other oceanic islands have APS minerals generated in near-surface environments where $\mathrm{P}$ is derived from bird guano [Trueman, 1965]. Previous investigators [Sayles, 1931; Ruhe et al., 1961] have suggested that birds or bats can provide $\mathrm{P}$ in the form of guano on Bermuda. There are 360 locally recorded bird species on Bermuda, of which 22 are actually resident [Raine, 2003]. Of the 22 resident bird species, half of these are native and two are endemic. For guano production, the most likely contributors would be the resident populations of sea birds (S. Olson, Smithsonian Institution, written communication, 2010), which include three species, the cahow (Pterodroma cahow), the white-tailed tropicbird or longtail (Phaethon lepturus catesbyi) and the common tern (Sterna hirundo). The fossil record also indicates that other species of sea birds once existed on Bermuda, such as the short-tailed albatross, Phoebastria albatrus, the Mediterranean shearwater Calonectris diomedea, and an auk (Pinguinus sp.) [Olson and Hearty, 2003]. In addition to sea birds, bats can also generate guano, and fossil bat bones of a variety of ages have been found in Quaternary deposits on Bermuda as well [Grady and Olson, 2006]. Because many bats are cave residents, however, it is not known how significant bat guano inputs to soils might be on Bermuda. We conclude that APS minerals on Bermuda likely formed from an unusually favorable combination of sources: Al from clay minerals in LRT dust, $\mathrm{S}$ from atmospheric sea salt, $\mathrm{Ca}$ from the local carbonate aeolianite, and $\mathrm{P}$ from bird guano and possibly apatite from local volcanic rocks.

[44] While almost any mineral in Bermuda's soils (carbonates, HIC, quartz, APS minerals) can, in principle, be explained by derivation from local sources, the geochemistry of the soils and paleosols cannot account for derivation solely from Bermudan volcanic rocks. When viewed on Sc-Th-La ternary plots, shallow Bermuda volcanic rocks and LRT dust (both African dust and North American distal loess) fall into clearly separated fields. Outside of the Whalebone Bay area, 
most Bermuda soils and paleosols fall between these two separate parent material fields, suggesting that the soils are derived in part from local volcanic sources, as proposed by Prognon et al. [2011] and in part from LRT dust, as proposed by Herwitz et al. [1996]. Soils from the Whalebone Bay area do not plot squarely in either parent material field, but fall closest to shallow Bermuda volcanic rocks, indicating this as the most likely parent material. Previous workers [Blackburn and Taylor, 1969, 1970; Bricker and Mackenzie, 1970; Herwitz et al., 1996] have noted that the modern beach sands and Quaternary aeolianites at Whalebone Bay have an unusually large number of volcanic particles, appearing as distinct black bands. Thus, sediments at Whalebone Bay have a larger proportion of local volcanic particles compared to all other localities on Bermuda.

[45] On Cr-Ta-Nd ternary plots, Bermuda volcanic rocks and LRT dust again define clearly separated fields. Bermuda soils and paleosols outside of Whalebone Bay fall outside the field defined by both shallow and deep volcanic rocks. These soils also fall mostly outside the LRT dust fields, but most plot much closer to the aeolian sources than to the volcanic rocks. Paleosols at Whalebone Bay, however, fall within or close to the shallow Bermuda volcanics field for $\mathrm{Cr}-\mathrm{Ta}-\mathrm{Nd}$. From the combination of Sc-Th-La and Cr-Ta-Nd plots, we conclude that paleosols at Whalebone Bay could be derived almost entirely from shallow volcanic rocks on Bermuda, but most other soils and paleosols are derived from some combination of local volcanic rocks and LRT dust. Rare earth element plots for paleosols at Whalebone Bay are consistent with a dominantly local volcanic source as well, although $\mathrm{Eu} / \mathrm{Eu}^{*}$ versus $\mathrm{La}_{\mathrm{N}} / \mathrm{Yb}_{\mathrm{N}}$ and $\mathrm{Eu} / \mathrm{Eu}^{*}$ versus $\mathrm{Gd}_{\mathrm{N}} / \mathrm{Yb}_{\mathrm{N}}$ plots suggest that LRT dust is a component of these paleosols as well. For soils and paleosols outside of Whalebone Bay, however, both standard chondritenormalized REE abundance plots and $\mathrm{Eu} / \mathrm{Eu}^{*}$ versus $\mathrm{La}_{\mathrm{N}} / \mathrm{Yb}_{\mathrm{N}}$ and $\mathrm{Eu} / \mathrm{Eu}^{*}$ versus $\mathrm{Gd}_{\mathrm{N}} / \mathrm{Yb}_{\mathrm{N}}$ plots indicate a dominance of LRT dust as the soil parent material.

[46] Although geochemical data for most of Bermuda's soils and paleosols require some component of upper continental crust as a contributing parent material, it is more difficult to ascertain which of the two LRT dust sources (Africa and North America) is the contributing parent material. Both African dust and Mississippi River loess have trace element compositions that closely resemble that of average upper continental crust, and it is of course possible that both of them are important parent materials for Bermuda soils. Nevertheless, the age range of Bermuda's soils and paleosols extends from at least the earliest part of the middle Quaternary (i.e., at least back to $\sim 700-800 \mathrm{ka}$ ) to the present and this provides some constraints on possible parent materials when geologic histories of the potential source materials are considered. Loess of last-glacial age in mid-continental North America is referred to as Peoria Loess and is extensive (Figure 1). Mass accumulation rates for Peoria Loess are among the highest in the world [Bettis et al., 2003] for the last glacial period. These high rates, combined with climate modeling [Mahowald et al., 2006], yield the potentially high fluxes of distal loess (LRT dust) from North America to Bermuda during the last glacial period (Figure 4b). Nevertheless, the loess stratigraphic record of central North America does not indicate that such high rates of loess accumulation are typical of the entire Quaternary Period. Stratigraphic records of loess for the Mississippi River valley from the upper part of the drainage basin in Illinois all the way to southern Mississippi indicate that pre-Peoria Loess deposits are much thinner than those of the last glacial period [Pye and Johnson, 1988; Markewich et al., 1998; Grimley et al., 2003]. Thus, the last-glacial period of Peoria Loess deposition may be unusual in the North American Quaternary record. Indeed, Mason et al. [2007] point out that in the Great Plains region of North America, exceptionally dry and windy conditions during the last glacial period may have produced the much thicker Peoria Loess deposits in that region as well, which differs from the pre-last-glacial loess record. If so, then the high rates of dust flux out of North America modeled by Mahowald et al. [2006] for the last glacial period (Figure 4b) are likely not representative of possible LRT dust inputs to Bermuda from the west during most of the Quaternary.

[47] On the other hand, longer-term geologic records of dust from Africa indicate that earlier glacial periods experienced only slightly lower dust flux than the last glacial period. For example, a deep-sea core taken from the eastern Atlantic (ODP site 659), off Mauritania (Figure 2), contains a record indicating that African dust flux has been important for at least the past $\sim 500 \mathrm{ka}$ (Figure 20). This record, which spans several interglacial-glacial cycles, shows that previous glacial periods of the past $\sim 500$ ka exhibit dust fluxes lower than, but comparable to that of the last glacial period, unlike the North American mid-continent loess record. African dust flux to latitudes higher than this, such as the Canary Basin off northwestern Africa, indicate a similar pattern, although the records here only go back to $\sim 250$ ka [Moreno et al., 2001]. In addition, although dust flux from Africa is highest during glacial periods, there is still considerable LRT dust transport during interglacial and interstadial periods (Figure 20). In contrast, little or no loess deposition along the Mississippi River valley has taken place during the Holocene. It is certainly possible that surface soils on Bermuda have received some input from distal Peoria Loess. However, all of Bermuda's buried paleosols that lie beneath aeolianites of Southampton Formation age or older would not likely have received significant LRT dust input from distal North America loess, because all such dust inputs would predate Peoria Loess, when aeolian deposition rates in the Mississippi River valley were of a much lower order. We conclude that the majority of upper continental crustal inputs to Bermuda's soils and paleosols likely came from LRT African dust.

[48] Long-term geologic records of dust flux, such as that from ODP Site 659 are, for the most part, located close to African dust sources, so it is useful to make some comparisons with modern dust flux measurements made along the western Atlantic Ocean. Using Fe as a mineral dust indicator and the average crustal abundance of this element, Prospero et al. [2010] reported average dust fluxes in Florida, measured statewide over a three-year period (1994-1996), of about $2 \mathrm{~g} \mathrm{~m}^{-2} \mathrm{yr}^{-1}$. Dust flux measurements on Bermuda, computed in the same way for a two-year period (19961997) are lower than Florida, around $0.4 \mathrm{~g} \mathrm{~m}^{-2} \mathrm{yr}^{-1}$, based on data in Kim et al. [1999]. It is pertinent to ascertain if the soil record on Bermuda is consistent with these data, along with the deep-sea record of dust flux during glacial periods.

[49] In order to estimate possible long-term African dust flux to Bermuda, we chose the modern surface soil at the Vesey Road section (the EQV series), shown in Figure 9b. The modern surface soil here has developed on the Rocky 


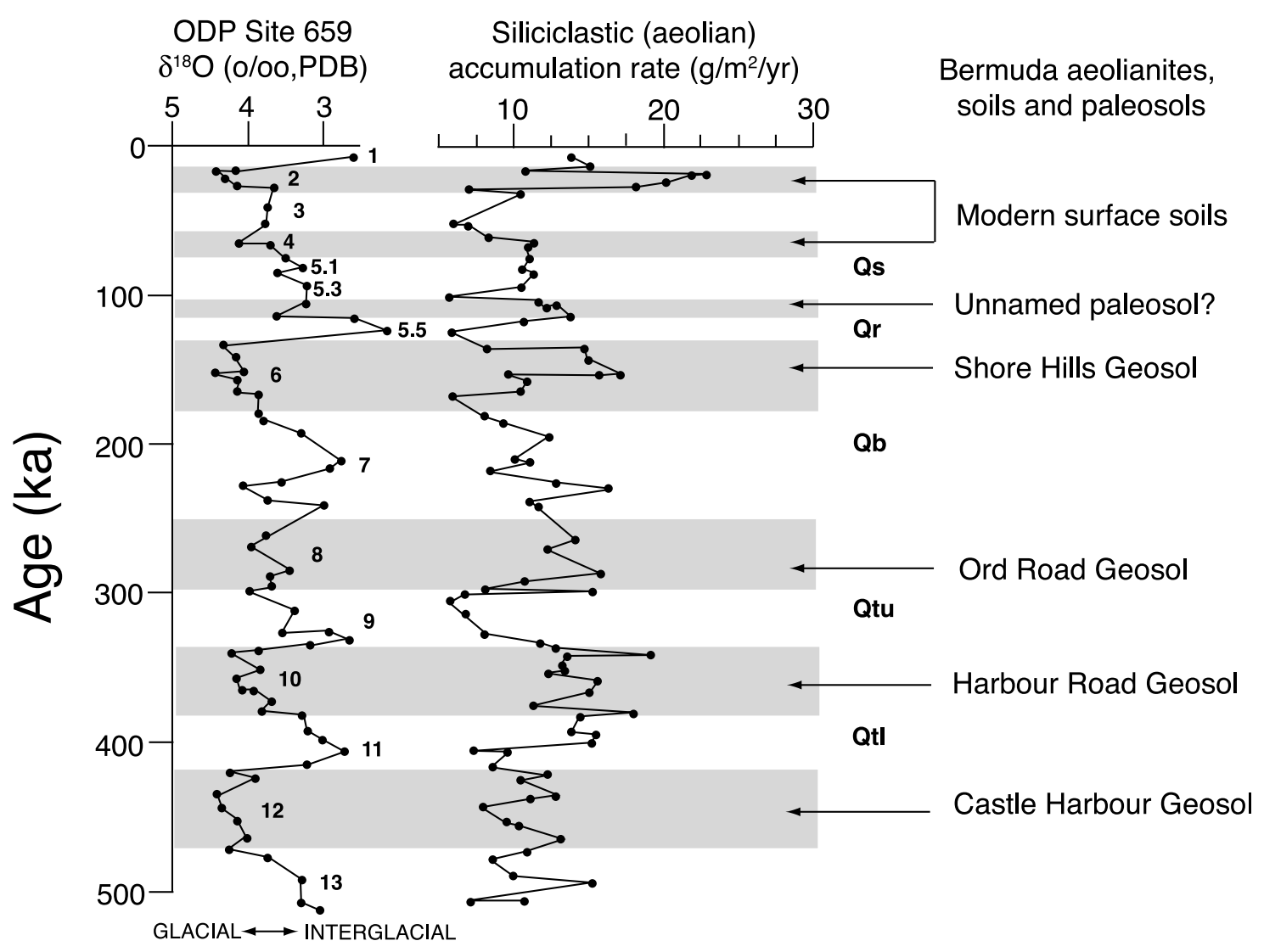

Figure 20. Oxygen isotope record of benthic foraminifera in deep-sea sediments at ODP Site 659 (Figure 2) in the eastern Atlantic Ocean [Sarnthein and Tiedemann, 1989], between the Cape Verde Islands and Cap Blanc, Mauritania, showing glacial-interglacial cycles over the past $\sim 1.0 \mathrm{Ma}$, and siliciclastic (aeolian) particle accumulation rate [Tiedemann et al., 1989]. Shades indicate glacial periods. Also shown are periods of deposition of aeolianites on Bermuda (Qs, Qr, Qb, Qtu, Qtl) and formation of Bermuda paleosols ("geosols"). Note that many Bermudan paleosols have formed over more than one glacial period, such as those shown in Figures 7, 8, 9, 11, and 12.

Bay aeolianite of last-interglacial age $(\sim 120,000 \mathrm{yr})$. The soil has an A horizon from 0 to $0.18 \mathrm{~m}$; a transitional $\mathrm{AB}$ horizon from 0.18 to $0.35 \mathrm{~m}$; and a $\mathrm{Bt}$ horizon from 0.35 to $0.56 \mathrm{~m}$, resting on aeolianite. In places, the Bt horizon is as deep as $\sim 1.07 \mathrm{~m}$, but this greater thickness is typically found where soil pipes have developed. Based on the Sc-Th-La data, this soil could be derived from a mix of African dust and local volcanic rock particles; based on $\mathrm{Eu} / \mathrm{Eu}^{*}$ and $\mathrm{La}_{\mathrm{N}}-\mathrm{Gd}_{\mathrm{N}}-\mathrm{Yb}_{\mathrm{N}}$ data, the soil could be derived mostly from African dust. For a first approximation, we assume conservatively that the soil is derived half from local volcanic particles and half from African dust. We further assume, for simplicity of calculations, a conservative thickness of $0.50 \mathrm{~m}$ for the whole soil profile. Based on measurements of loess and loessderived soils [e.g., Muhs et al., 2003], we assume a bulk density of $1.4 \mathrm{~g} \mathrm{~cm}^{-3}\left(=1.4 \times 10^{6} \mathrm{~g} \mathrm{~m}^{-3}\right)$. Thus, if half the soil profile $(\sim 0.25 \mathrm{~m})$ is African-dust-derived, this yields $35 \mathrm{~g}$ of aeolian-derived soil in each $1-\mathrm{cm}^{2}$ soil column (or $350,000 \mathrm{~g}$ in a $1-\mathrm{m}^{2}$ soil column) over the history of pedogenesis. With the age of the Rocky Bay Formation aeolianite estimated to be $\sim 120,000 \mathrm{yr}$ [Muhs et al., 2002], this yields an aeolian mass accumulation rate of $\sim 2.9 \mathrm{~g} \mathrm{~m}^{-2} \mathrm{yr}^{-1}$. This rate is close to the maximum modern dust flux measurements reported by
Prospero et al. [2010] for Florida, but is greater than modern rates estimated for Bermuda, based on data in Kim et al. [1999]. Nevertheless, dust fluxes from Africa to Bermuda were probably greater during the last glacial period, based on the long-term record at ODP Site 659. Furthermore, the longterm African dust flux to Bermuda we estimate here is considerably lower than those measured for either glacial or interglacial periods close to sources in Africa (Figure 20). Thus, we regard the estimate as a reasonable first approximation, but caution that better estimates could be made by more soil thickness measurements and geochemical modeling that could yield a precise estimate of the portion of the soil that is dust derived.

\section{Summary and Conclusions}

[50] There has long been debate over the origin of terra rossa soils and paleosols on relatively pure carbonate aeolianites of Quaternary age on Bermuda. Hypotheses of both a residual origin, supplied by minor local volcanic minerals in the aeolianites, and LRT dust, either from Africa or North America, have had their advocates for many decades. In the present study, these soil parent materials are characterized by mineralogy and geochemistry. Ratios of relatively immobile 
trace elements differentiate the competing parent materials. Sc-Th-La, Cr-Th-Nd, Eu/Eu*, $\mathrm{La}_{\mathrm{N}} / \mathrm{Yb}_{\mathrm{N}}$, and $\mathrm{Gd}_{\mathrm{N}} / \mathrm{Yb}_{\mathrm{N}}$, are distinctive for African dust, collected on both Barbados and Bermuda, and lower Mississippi River valley loess, when compared to local volcanic sources.

[51] The mineralogy of the soils and paleosols on Bermuda is an unusual mix of detrital carbonates, clay minerals dominated by hydroxy-interlayered clay, quartz and a phosphate mineral, likely woodhouseite or possibly crandallite. The carbonates are derived locally, from skeletal sands generated by marine invertebrate remains. The phosphate mineral or minerals likely formed from a favorable combination of sources of $\mathrm{Al}, \mathrm{P}, \mathrm{S}$, and $\mathrm{Ca}$, with $\mathrm{Al}$ from clay minerals, $\mathrm{P}$ from bird guano, $\mathrm{S}$ from marine aerosol sources, and $\mathrm{Ca}$ from local carbonate aeolianite. The source of the clay minerals, dominated by hydroxy-interlayered clays, in Bermuda's soils and paleosols, can be ascertained by trace element geochemistry. Bermuda soils have Sc-Th-La, Cr-Ta-Nd, Eu/Eu*, $\mathrm{La}_{\mathrm{N}} / \mathrm{Yb}_{\mathrm{N}}$, and $\mathrm{Gd}_{\mathrm{N}} / \mathrm{Yb}_{\mathrm{N}}$ that, when considered collectively, indicate derivation from some combination of local volcanic bedrock and LRT dust.

[52] Of the two LRT dust parent materials, African dust is likely to have been the more important aeolian influence. Fluxes of distal loess from North America, while very high during the last glacial period, were probably much lower during earlier glacial periods and likely not significant during interglacial periods of the Quaternary, based on the loess stratigraphic record. In contrast, the record of African dust flux to the Atlantic, taken from deep-sea cores, indicates that this potential soil parent material may have been important during both glacial and interglacial periods, throughout the past $\sim 500 \mathrm{ka}$. Based on the stratigraphic record we observe in the field, many of Bermuda's soils and paleosols also formed during intervals of this same $500 \mathrm{ka}$ period. Although a local volcanic contribution can be detected by geochemistry in many of our samples, Bermuda's soils and paleosols cannot be explained by derivation from the local volcanic rocks alone. We conclude that African dust has likely been an important contributor to Bermuda's soils for a good part of the past $\sim 500 \mathrm{ka}$.

[53] Acknowledgments. D. Muhs, J. Budahn, and G. Skipp's work in this study was supported by the Climate and Land Use Change Program of the U.S. Geological Survey and is a contribution to the "Impacts of climate change on coastal and eolian landscapes" project. J. M. Prospero acknowledges support from NSF grants OCE-0623189 and AGS-0962256. Field work was supported by a grant from the National Geographic Society to S. Herwitz and D. Muhs. We thank the Bermuda Biological Station for Research for lodging, David B. Scott (Dalhousie University) for providing splits of the Bermuda volcanic drill core, Diana Johnson and Donald Lee Johnson (University of Illinois) for providing photographs of two of our study localities, and Randy Schumann (U.S. Geological Survey) for assistance collecting soils on the Florida Keys and Bahamas. We appreciate very helpful discussions of Bermuda's birds and bats with Storrs Olson (Smithsonian Institution). A special thanks goes to Len Vacher (University of South Florida) for many stimulating discussions of Bermuda's geology. We thank Alexander Densmore and Douglas Sherman (JGR editors), Onn Crouvi (Geological Survey of Israel), Joan Fitzpatrick and Tom Judkins (U.S. Geological Survey), and two anonymous JGR reviewers for very helpful comments on an earlier version of the manuscript.

\section{References}

Anthony, J. W., et al. (2000), Handbook of Mineralogy, vol. 4, Arsenates, Phosphates, Vanadates, Mineral. Soc. of Am., Chantilly, Va.

Arimoto, R. (2001), Eolian dust and climate: Relations to sources, tropospheric chemistry, transport and deposition, Earth Sci. Rev., 54, 29-42, doi:10.1016/S0012-8252(01)00040-X.
Arimoto, R., R. A. Duce, D. L. Savoie, and J. M. Prospero (1992), Trace elements in aerosol particles from Bermuda and Barbados: Concentrations, sources and relationships to aerosol sulfate, J. Atmos. Chem., 14, 439-457, doi:10.1007/BF00115250.

Arimoto, R., R. A. Duce, B. J. Ray, W. G. Ellis Jr., J. D. Cullen, and J. T. Merrill (1995), Trace elements in the atmosphere over the North Atlantic, J. Geophys. Res., 100, 1199-1213, doi:10.1029/94JD02618.

Arimoto, R., R. A. Duce, B. J. Ray, and U. Tomza (2003), Dry deposition of trace elements to the western Atlantic Ocean, Global Biogeochem. Cycles, 17(1), 1010, doi:10.1029/2001GB001406.

Barnhisel, R. I., and P. M. Bertsch (1989), Chlorites and hydroxyinterlayered vermiculite and smectite, in Minerals in Soil Environments, edited by J. B. Dixon and S. B. Weed, pp. 729-788, Soil Sci. Soc. of Am., Madison, Wis.

Bettis, E. A., III, D. R. Muhs, H. M. Roberts, and A. G. Wintle (2003), Last glacial loess in the conterminous U.S.A, Quat. Sci. Rev., 22, 1907-1946, doi:10.1016/S0277-3791(03)00169-0.

Birkeland, P. W. (1999), Soils and Geomorphology, 3rd ed., 430 pp., Oxford Univ. Press, New York.

Blackburn, G., and R. M. Taylor (1969), Limestones and red soils of Bermuda, Geol. Soc. Am. Bull., 80, 1525-1598, doi:10.1130/00167606(1969)80[1595:LARSOB]2.0.CO;2.

Blackburn, G., and R. M. Taylor (1970), Limestones and red soils of Bermuda: Reply, Geol. Soc. Am. Bull., 81, 2525-2526, doi:10.1130/ 0016-7606(1970)81[2525:LARSOB]2.0.CO;2.

Bretz, J. H. (1960), Bermuda: A partially drowned, late mature, Pleistocene karst, Geol. Soc. Am. Bull., 71, 1729-1754, doi:10.1130/0016-7606 (1960)71[1729:BAPDLM]2.0.CO;2.

Bricker, O., and F. T. Mackenzie (1970), Limestones and red soils of Bermuda: Discussion, Geol. Soc. Am. Bull., 81, 2523-2524, doi:10.1130/ 0016-7606(1970)81[2523:LARSOB]2.0.CO;2.

Budahn, J. R., and G. A. Wandless (2002), Instrumental neutron activation by long count, in Analytical Methods for Chemical Analysis of Geologic and Other Materials, U.S. Geol. Surv. Open File Rep., 02$0223, \mathrm{X}-1-\mathrm{X}-13$.

Delany, A. C., A. C. Delany, D. W. Parkin, J. J. Griffin, E. D. Goldberg, and B. E. F. Reimann (1967), Airborne dust collected at Barbados, Geochim. Cosmochim. Acta, 31, 885-909, doi:10.1016/S0016-7037(67) 80037-1.

Dill, H. G. (2001), The geology of aluminum phosphates and sulphates of the alunite group minerals: A review, Earth Sci. Rev., 53, 35-93, doi:10.1016/S0012-8252(00)00035-0.

Dill, H. G. (2010), The "chessboard" classification scheme of mineral deposits: Mineralogy and geology from aluminum to zirconium, Earth Sci. Rev., 100, 1-420, doi:10.1016/j.earscirev.2009.10.011.

Durn, G. (2003), Terra rossa in the Mediterranean region: Parent materials, composition and origin, Geol. Croat., 56, 83-100.

Engleman, E. E., L. L. Jackson, and D. R. Norton (1985), Determination of carbonate carbon in geological materials by coulometric titration, Chem. Geol., 53, 125-128, doi:10.1016/0009-2541(85)90025-7.

Foos, A. M., and R. J. Bain (1995), Mineralogy, chemistry, and petrography of soils, surface crusts, and soil stones, San Salvador and Eleuthera, Bahamas, Spec. Pap. Geol. Soc. Am., 300, 223-232.

Gallet, S., B. Jahn, and M. Torii (1996), Geochemical characterization of the Luochuan loess-paleosol sequence, China, and paleoclimatic implications, Chem. Geol., 133, 67-88, doi:10.1016/S0009-2541(96)00070-8.

Glaccum, R. A., and J. M. Prospero (1980), Saharan aerosols over the tropical North Atlantic-mineralogy, Mar. Geol., 37, 295-321, doi:10.1016/ 0025-3227(80)90107-3.

Grady, F. V., and S. L. Olson (2006), Fossil bats from Quaternary deposits on Bermuda (Chiroptera: Vespertilionidae), J. Mammal., 87, 148-152, doi:10.1644/05-MAMM-A-179R1.1.

Grimley, D. A., L. R. Follmer, R. E. Hughes, and P. A. Solheid (2003), Modern, Sangamon and Yarmouth soil development in loess of unglaciated southwestern Illinois, Quat. Sci. Rev., 22, 225-244, doi:10.1016/ S0277-3791(02)00039-2.

Harmon, R. S., R. M. Mitterer, N. Kriausakul, L. S. Land, H. P. Schwarcz, P. Garrett, G. J. Larson, H. L. Vacher, and M. Rowe (1983), Uraniumseries and amino-acid racemization geochronology of Bermuda: Implications for eustatic sea-level fluctuations over the past 250,000 years, Palaeogeogr. Palaeoclimatol. Palaeoecol., 44, 41-70, doi:10.1016/ 0031-0182(83)90004-4.

Hearty, P. J., H. L. Vacher, and R. M. Mitterer (1992), Aminostratigraphy and ages of Pleistocene limestones of Bermuda, Geol. Soc. Am. Bull., 104, 471-480, doi:10.1130/0016-7606(1992)104<0471:AAAOPL $>2.3$. $\mathrm{CO} ; 2$.

Herwitz, S. R. (1993), Stemflow influences on the formation of solution pipes in Bermuda eolianite, Geomorphology, 6, 253-271, doi:10.1016/ 0169-555X(93)90050-C. 
Herwitz, S. R., and D. R. Muhs (1995), Bermuda solution pipe soils: A geochemical evaluation of eolian parent materials, Spec. Pap. Geol. Soc. Am., 300, 311-323, doi:10.1130/0-8137-2300-0.311.

Herwitz, S. R., D. R. Muhs, J. M. Prospero, S. Mahan, and B. Vaughn (1996), Origin of Bermuda's clay-rich Quaternary paleosols and their paleoclimatic significance, J. Geophys. Res., 101, 23,389-23,400, doi:10.1029/96JD02333.

Hole, F. D. (1981), Effects of animals on soil, Geoderma, 25, 75-112, doi:10.1016/0016-7061(81)90008-2.

Husar, R. B., J. M. Prospero, and L. L. Stowe (1997), Characterization of tropospheric aerosols over the oceans with the NOAA advanced very high resolution radiometer optical thickness operational product, J. Geophys. Res., 102, 16,889-16,909, doi:10.1029/96JD04009.

Imbrie, J., J. D. Hays, D. G. Martinson, A. McIntyre, A. C. Mix, J. J. Morley, N. G. Pisias, W. L. Prell, and N. J. Shackleton (1984), The orbital theory of Pleistocene climate: Support from a revised chronology of the marine $\mathrm{d} 180$ record, in Milankovitch and Climate: Understanding the Response to Astronomical Forcing, NATO Adv. Study Inst. Ser., vol. 126, edited by A. Berger et al., pp. 269-305, D. Reidel, Dordrecht, Netherlands.

Jahn, B., S. Gallet, and J. Han (2001), Geochemistry of the Xining, Xifeng and Jixian sections, Loess Plateau of China: Eolian dust provenance and paleosol evolution during the last $140 \mathrm{ka}$, Chem. Geol., 178, 71-94, doi:10.1016/S0009-2541(00)00430-7.

Johnson, D. L., J. E. J. Domier, and D. N. Johnson (2005), Animating the biodynamics of soil thickness using process vector analysis: A dynamic denudation approach to soil formation, Geomorphology, 67, 23-46, doi:10.1016/j.geomorph.2004.08.014

Kim, G., L. Alleman, and T. M. Church (1999), Atmospheric depositional fluxes of trace elements, ${ }^{210} \mathrm{~Pb}$, and ${ }^{7} \mathrm{Be}$ to the Sargasso Sea, Global Biogeochem. Cycles, 13(4), 1183-1192, doi:10.1029/1999GB900071.

Land, L. S., F. T. MacKenzie, and S. J. Gould (1967), Pleistocene history of Bermuda, Geol. Soc. Am. Bull., 78, 993-1006, doi:10.1130/0016-7606 (1967)78[993:PHOB]2.0.CO;2.

Mackenzie, F. T. (1964a), Geometry of Bermuda calcareous dune crossbedding, Science, 144, 1449-1450, doi:10.1126/science.144.3625.1449.

Mackenzie, F. T. (1964b), Bermuda Pleistocene eolianites and paleowinds, Sedimentology, 3, 52-64, doi:10.1111/j.1365-3091.1964.tb00275.x.

Mahowald, N. M., D. R. Muhs, S. Levis, P. J. Rasch, M. Yoshioka, C. S. Zender, and C. Luo (2006), Change in atmospheric mineral aerosols in response to climate: Last glacial period, preindustrial, modern, and doubled carbon dioxide climates, J. Geophys. Res., 111, D10202, doi:10.1029/2005JD006653.

Markewich, H. W., D. A. Wysocki, M. J. Pavich, E. M. Rutledge, H. T Millard Jr., F. J. Rich, P. B. Maat, M. Rubin, and J. P. McGeehin (1998), Paleopedology plus TL, ${ }^{10} \mathrm{Be}$, and ${ }^{14} \mathrm{C}$ dating as tools in stratigraphic and paleoclimatic investigations, Mississippi River Valley, USA, Quat. Int., 51-52, 143-167, doi:10.1016/S1040-6182(97)00041-4.

Mason, J. A., R. M. Joeckel, and E. A. Bettis III (2007), Middle to Late Pleistocene loess record in eastern Nebraska, USA, and implications for the unique nature of Oxygen Isotope Stage 2, Quat. Sci. Rev., 26, 773-792, doi:10.1016/j.quascirev.2006.10.007.

McLennan, S. M. (1989), Rare earth elements in sedimentary rocks Influence of provenance and sedimentary processes, Rev. Mineral. 21, 169-200.

Moreno, A., J. Targarona, J. Henderiks, M. Canals, T. Freudenthal, and H. Meggers (2001), Orbital forcing of dust supply to the North Canary Basin over the last 250 kyr, Quat. Sci. Rev., 20, 1327-1339, doi:10.1016/S0277-3791(00)00184-0.

Muhs, D. R., and J. R. Budahn (2006), Geochemical evidence for the origin of late Quaternary loess in central Alaska, Can. J. Earth Sci. 43, 323-337, doi:10.1139/e05-115.

Muhs, D. R., and J. R. Budahn (2009), Geochemical evidence for African dust and volcanic ash inputs to terra rossa soils on carbonate reef terraces, northern Jamaica, West Indies, Quat. Int., 196, 13-35, doi:10.1016/ j.quaint.2007.10.026

Muhs, D. R., E. A. Bettis III, J. Been, and J. McGeehin (2001), Impact of climate and parent material on chemical weathering in loess-derived soils of the Mississippi River Valley, Soil Sci. Soc. Am. J., 65, 1761-1777, doi:10.2136/sssaj2001.1761.

Muhs, D. R., K. R. Simmons, and B. Steinke (2002), Timing and warmth of the last interglacial period: New U-series evidence from Hawaii and Bermuda and a new fossil compilation for North America, Quat. Sci. Rev., 21, 1355-1383, doi:10.1016/S0277-3791(01)00114-7.

Muhs, D. R., T. A. Ager, E. A. Bettis III, J. McGeehin, J. M. Been, J. E. Begét, M. J. Pavich, T. W. Stafford Jr., and D. S. P. Stevens (2003), Stratigraphy and paleoclimatic significance of late Quaternary loess-paleosol sequences of the Last Interglacial-Glacial cycle in central Alaska, Quat. Sci. Rev., 22, 1947-1986, doi:10.1016/S0277-3791(03)00167-7.
Muhs, D. R., J. Budahn, J. M. Prospero, and S. N. Carey (2007a), Geochemical evidence for African dust inputs to soils of western Atlantic islands: Barbados, the Bahamas and Florida, J. Geophys. Res., 112 F02009, doi:10.1029/2005JF000445.

Muhs, D. R., J. Budahn, M. Reheis, J. Beann, G. Skipp, and E. Fisher (2007b), Airborne dust transport to the eastern Pacific Ocean off southern California: Evidence from San Clemente Island, J. Geophys. Res., 112, D13203, doi:10.1029/2006JD007577.

Muhs, D. R., J. Budahn, D. L. Johnson, M. Reheis, J. Beann, G. Skipp, E. Fisher, and J. A. Jones (2008), Geochemical evidence for airborne dust additions to soils in Channel Islands National Park, California, Geol. Soc. Am. Bull., 120, 106-126, doi:10.1130/B26218.1.

Muhs, D. R., J. Budahn, A. Avila, G. Skipp, J. Freeman, and D. Patterson (2010a), Geochemical evidence for African dust additions to Quaternary soils on the island of Mallorca, Spain, Quat. Sci. Rev., 29, 2518-2543, doi:10.1016/j.quascirev.2010.04.013

Muhs, D. R., J. Budahn, G. Skipp, J. M. Prospero, D. Patterson, and E. A. Bettis III (2010b), Mineralogical and geochemical evidence for Sahara and Sahel dust additions to Quaternary soils on Lanzarote, eastern Canary Islands, Spain, Terra Nova, 22, 399-410, doi:10.1111/j.1365 3121.2010.00949.x.

Muhs, D. R., K. R. Simmons, R. R. Schumann, and R. B. Halley (2011), Sea-level history of the past two interglacial periods: New evidence from U-series dating of reef corals from south Florida, Quat. Sci. Rev., 30, 570-590, doi:10.1016/j.quascirev.2010.12.019.

Nakai, S., A. N. Halliday, and D. K. Rea (1993), Provenance of dust in the Pacific Ocean, Earth Planet. Sci. Lett., 119, 143-157, doi:10.1016/0012821X(93)90012-X.

Olivarez, A. M., R. M. Owen, and D. K. Rea (1991), Geochemistry of eolian dust in Pacific pelagic sediments: Implications for paleoclimatic interpretations, Geochim. Cosmochim. Acta, 55, 2147-2158, doi:10.1016/ 0016-7037(91)90093-K.

Olson, S. L., and P. J. Hearty (2003), Probable extirpation of a breeding colony of short-tailed albatross (Phoebastria albatrus) on Bermuda by Pleistocene sea-level rise, Proc. Natl. Acad. Sci. U. S. A., 100, 12,825-12,829, doi:10.1073/pnas.1934576100.

Perry, K. D., T. A. Cahill, R. A. Eldred, D. D. Dutcher, and T. E. Gill (1997), Long-range transport of North African dust to the eastern United States, J. Geophys. Res., 102, 11,225-11,238, doi:10.1029/97JD00260.

Prognon, F., I. Cojan, P. Kindler, M. Thiry, and M. Demange (2011), Mineralogical evidence for a local volcanic origin of the parent material of Bermuda Quaternary paleosols, Quat. Res., 75, 256-266, doi:10.1016/ j.yqres.2010.08.002

Prospero, J. M. (1999), Long-term measurements of the transport of African mineral dust to the southeastern United States: Implications for regional air quality, J. Geophys. Res., 104, 15,917-15,927, doi:10.1029/ 1999JD900072.

Prospero, J. M. (2002), The chemical and physical properties of marine aerosols: An introduction, in Chemistry of Marine Water and Sediments, edited by A. Gianguzza, E. Pellizzetti, and S. Sammarano, pp. 35-82, Springer, Heidelberg, Germany.

Prospero, J. M., and T. N. Carlson (1972), Vertical and areal distribution of Saharan dust over the western equatorial North Atlantic Ocean, J. Geophys. Res., 77, 5255-5265, doi:10.1029/JC077i027p05255.

Prospero, J. M., and P. J. Lamb (2003), African droughts and dust transport to the Caribbean: Climate change implications, Science, 302, 1024-1027, doi:10.1126/science. 1089915 .

Prospero, J. M., and R. T. Nees (1977), Dust concentration in the atmosphere of the equatorial North Atlantic: Possible relationship to the Sahelian drought, Science, 196, 1196-1198, doi:10.1126/science.196.4295.1196. Prospero, J. M., and R. T. Nees (1986), Impact of the North African drought and El Niño on mineral dust in the Barbados trade winds, Nature, 320 , 735-738, doi:10.1038/320735a0.

Prospero, J. M., and R. T. Nees (1987), Deposition rate of particulate and dissolved aluminum derived from Saharan dust in precipitation at Miami, Florida, J. Geophys. Res., 92, 14,723-14,731, doi:10.1029/ JD092iD12p14723.

Prospero, J. M., E. Bonatti, C. Schubert, and T. N. Carlson (1970), Dust in the Caribbean atmosphere traced to an African dust storm, Earth Planet. Sci. Lett., 9, 287-293, doi:10.1016/0012-821X(70)90039-7.

Prospero, J. M., R. A. Glaccum, and R. T. Nees (1981), Atmospheric transport of soil dust from Africa to South America, Nature, 289, 570-572, doi:10.1038/289570a0.

Prospero, J. M., R. T. Nees, and M. Uematsu (1987), Deposition rate of particulate and dissolved aluminum derived from Saharan dust in precipitation at Miami, Florida, J. Geophys. Res., 92, 14,723-14,731, doi:10.1029/JD092iD12p14723.

Prospero, J. M., I. Olmez, and M. Ames (2001), Al and Fe in PM 2.5 and PM 10 suspended particles in south-central Florida: The impact 
of the long range transport of African mineral dust, Water Air Soil Pollut., 125(1), 291-317, doi:10.1023/A:1005277214288.

Prospero, J. M., W. M. Landing, and M. Schulz (2010), African dust deposition in Florida: Temporal and spatial variability and comparison to models, J. Geophys. Res., 115, D13304, doi:10.1029/2009JD012773.

Pye, K., and R. Johnson (1988), Stratigraphy, geochemistry, and thermoluminescence ages of lower Mississippi Valley loess, Earth Surf. Processes Landforms, 13, 103-124, doi:10.1002/esp.3290130203.

Raine, A. (2003), A Field Guide to the Birds of Bermuda, 146 pp., Macmillan, Oxford, U. K.

Reynolds, P. H., and F. Aumento (1974), Deep Drill 1972. Potassium-argon dating of the Bermuda drill core, Can. J. Earth Sci., 11, 1269-1273, doi:10.1139/e74-118

Rognon, P., G. Coudé-Gaussen, M. Revel, F. E. Grousset, and P. Pedemay (1996), Holocene Saharan dust deposition on the Cape Verde Islands: Sedimentological and Nd-Sr isotopic evidence, Sedimentology, 43, 359-366, doi:10.1046/j.1365-3091.1996.d01-8.x.

Ruhe, R. V., J. G. Cady, and R. S. Gomez (1961), Paleosols of Bermuda, Geol. Soc. Am. Bull., 72, 1121-1142, doi:10.1130/0016-7606(1961)72 [1121:POB]2.0.CO;2.

Sarnthein, M., and R. Tiedemann (1989), Toward a high-resolution stable isotope stratigraphy of the last 3.4 million years: Sites 658 and 659 off northwest Africa, Proc. Ocean Drill. Program Sci. Res., 108, 167-185.

Savoie, D., R. Arimoto, W. C. Keene, J. M. Prospero, R. A. Duce, and J. N. Galloway (2002), Marine biogenic and anthropogenic contributions to non-sea-salt sulfate in the marine boundary layer over the North Atlantic Ocean, J. Geophys. Res., 107(D18), 4356, doi:10.1029/2001JD000970.

Sayles, R. W. (1931), Bermuda during the ice age, Proc. Am. Acad. Arts Sci., 66, 381-467, doi:10.2307/20026356.

Schaetzl, R. J., and S. Anderson (2005), Soils: Genesis and Geomorphology, 817 pp., Cambridge Univ. Press, Cambridge, U. K., doi:10.1017 CBO9780511815560.

Sholkovitz, E. R., T. M. Church, and R. Arimoto (1993), Rare earth element composition of precipitation, precipitation particles, and aerosols, J. Geophys. Res., 98, 20,587-20,599, doi:10.1029/93JD01926.

Singer, A. (2007), The Soils of Israel, 306 pp., Springer, Berlin.

Snowden, J. O., Jr., and R. R. Priddy (1968), Loess Investigations in Mississippi: Geology of Mississippi Loess, Bull. Miss. Geol. Econ. Topogr. Surv., 111, $267 \mathrm{pp}$.
Sun, J. (2002), Provenance of loess material and formation of loess deposits on the Chinese Loess Plateau, Earth Planet. Sci. Lett., 203, 845-859, doi:10.1016/S0012-821X(02)00921-4.

Talbot, R. W., R. C. Harriss, E. V. Browell, G. L. Gregory, D. I. Sebacher, and S. M. Beck (1986), Distribution and geochemistry of aerosols in the tropical North Atlantic troposphere: Relationship to Saharan dust, J. Geophys. Res., 91, 5173-5182, doi:10.1029/JD091iD04p05173.

Taylor, S. R., and S. M. McLennan (1985), The Continental Crust: Its Composition and Evolution, 312 pp., Blackwell Sci., Oxford, U. K.

Taylor, S. R., and S. M. McLennan (1995), The geochemical evolution of the continental crust, Rev. Geophys., 33, 241-265, doi:10.1029/ 95RG00262.

Thompson, C. W. (1878), The Atlantic: A Preliminary Account of the General Results of the Exploring Voyage of the H.M.S. "Challenger" During the Year 1873 and the Early Part of the Year 1876, vol. 1, 391 pp., Harper, New York.

Tiedemann, R., M. Sarnthein, and R. Stein (1989), Climatic changes in the Western Sahara: Aeolo-marine sediment record of the last 8 million years (sites 657-661), Proc. Ocean Drill. Program Sci. Res., 108, 241-277.

Trueman, N. A. (1965), The phosphate, volcanic and carbonate rocks of Christmas Island (Indian Ocean), J. Geol. Soc. Aust., 12, 261-283, doi:10.1080/00167616508728596.

Tsoar, H., and K. Pye (1987), Dust transport and the question of desert loess formation, Sedimentology, 34, 139-153, doi:10.1111/j.1365-3091.1987. tb00566.x.

Vacher, H. L., and M. P. Rowe (1997), Geology and hydrology of Bermuda, in Geology and Hydrology of Carbonate Islands, Dev. Sedimentol., vol. 54, edited by H. L. Vacher and T. M. Quinn, pp. 35-90, Elsevier, Amsterdam.

Vacher, H. L., M. P. Rowe, and P. Garrett (1989), The geological map of Bermuda, scale 1:25,000, Public Works Dep., Hamilton, Bermuda.

Vacher, H. L., P. J. Hearty, and M. P. Rowe (1995), Stratigraphy of Bermuda: Nomenclature, concepts, and status of multiple systems of classification, Geol. Soc. Am. Spec. Pap., 300, 271-294, doi:10.1130/0-81372300-0.271.

Verrill, A. E. (1902), The Bermuda Islands: Their scenery, climate, productions, natural history, and geology, Trans. Conn. Acad. Arts Sci., 11, 413-956.

Wetterer, J. K., and A. L. Wetterer (2004), Ants (Hymenoptera: Formicidae) of Bermuda, Fla. Entomol., 87, 212-221, doi:10.1653/0015-4040(2004) 087[0212:AHFOB]2.0.CO;2. 
Auxiliary Material for

\section{Soil genesis on the island of Bermuda in the Quaternary: The importance of African dust transport and deposition}

Daniel R. Muhs and James R. Budahn

U.S. Geological Survey, Denver, Colorado, USA

Joseph M. Prospero

Rosenstiel School of Marine and Atmospheric Sciences, University of Miami, Miami, Florida, USA

Gary Skipp

U.S. Geological Survey, MS 980, Denver, Colorado, USA

Stanley R. Herwitz

UAV Collaborative, NASA Research Park, Moffett Field, California, USA

Muhs, D. R., J. R. Budahn, J. M. Prospero, G. Skipp, and S. R. Herwitz (2012), Soil genesis on the island of Bermuda in the Quaternary: The importance of African dust transport and deposition, J. Geophys. Res., 117, F03025, doi:10.1029/2012JF002366.

\section{Introduction}

Auxiliary material provided here includes three tables that give the major element concentrations (in weight percent) and mineral identifications of samples taken from the bedrock core collected on Bermuda; the trace element concentrations (in parts per million) of samples taken from the bedrock core on Bermuda; and the trace element concentrations (in parts per million) of soil and paleosol samples collected on Bermuda.

Data Set S1.

Major element concentrations (in weight percent) of samples from bedrock core on Bermuda, obtained by wavelengthdispersive $\mathrm{X}$-ray fluorescence and mineralogy of these samples (obtained by X-ray diffraction)

Data Set S2.

race element concentrations (in parts per million) and some major element concentrations (in weight percent) of samples from bedrock core on Bermuda, obtained by instrumental neutron activation analysis.

Data Set S3.

Trace element concentrations (in parts per million) and some major element concentrations (in weight percent) of soil and paleosol samples collected on Bermuda, obtained by instrumental neutron activation analysis. Latitude and longitude of all sample localities are also provided. 
Supplementary Data Table 1. Major element concentrations and mineralogy of volcanic rocks from Bermuda.

\begin{tabular}{|c|c|c|c|c|c|c|c|c|c|c|c|c|c|c|c|c|}
\hline Sample ID & $\begin{array}{l}\text { Depth } \\
\text { (m) }\end{array}$ & $\begin{array}{l}\mathrm{SiO}_{2} \\
\%\end{array}$ & $\begin{array}{l}\mathrm{Al}_{2} \mathrm{O}_{3} \\
\%\end{array}$ & $\begin{array}{l}\mathrm{Fe}_{2} \mathrm{O}_{3} \\
\%\end{array}$ & $\begin{array}{l}\mathrm{MgO} \\
\%\end{array}$ & $\begin{array}{l}\mathrm{CaO} \\
\%\end{array}$ & $\begin{array}{l}\mathrm{Na}_{2} \mathrm{O} \\
\%\end{array}$ & $\begin{array}{l}\mathrm{K}_{2} \mathrm{O} \\
\%\end{array}$ & $\begin{array}{l}\mathrm{TiO}_{2} \\
\%\end{array}$ & $\begin{array}{l}\mathrm{P}_{2} \mathrm{O}_{5} \\
\%\end{array}$ & $\begin{array}{l}\mathrm{MnO} \\
\%\end{array}$ & $\begin{array}{l}\mathrm{Cr}_{2} \mathrm{O}_{3} \\
\%\end{array}$ & $\begin{array}{l}\mathrm{V}_{2} \mathrm{O}_{5} \\
\%\end{array}$ & $\begin{array}{l}\text { LOI } \\
\%\end{array}$ & $\begin{array}{l}\text { Sum } \\
\%\end{array}$ & Minerals* \\
\hline Bermuda-1 & 38.9 & 37.7 & 11.4 & 13.6 & 6.89 & 13.9 & 3 & 2.06 & 5.02 & 1.08 & 0.23 & 0.01 & 0.1 & 5.31 & 100.3 & MA, MI, AU, Z, O, D, CL \\
\hline Bermuda-2 & 40.6 & 36.4 & 10.7 & 13.3 & 6.75 & 13.5 & 1.46 & 4.39 & 4.81 & 1.02 & 0.21 & $<0.01$ & 0.08 & 8.32 & 100.8 & MA, D, MI, CA \\
\hline Bermuda-3 & 43.6 & 38 & 11.1 & 14 & 8.54 & 14.1 & 2.08 & 2.07 & 4.99 & 0.95 & 0.22 & 0.03 & 0.09 & 3.96 & 100.1 & $\mathrm{MA}, \mathrm{Z}, \mathrm{D}, \mathrm{Ml}, \mathrm{CA}$ \\
\hline Bermuda-5 & 48.1 & 36.7 & 10.3 & 13.7 & 8.15 & 11.5 & 2.42 & 2.49 & 4.68 & 0.92 & 0.17 & 0.04 & 0.08 & 9.24 & 100.3 & $\mathrm{MA}, \mathrm{Z}, \mathrm{D}, \mathrm{CL}, \mathrm{MI}, \mathrm{CA}$ \\
\hline Bermuda-6 & 49.2 & 37.3 & 9.38 & 13.8 & 8.82 & 14.5 & 1.89 & 2.3 & 4.66 & 0.8 & 0.2 & 0.03 & 0.08 & 6.95 & 100.6 & $\mathrm{MA}, \mathrm{D}, \mathrm{CL}, \mathrm{MI}, \mathrm{CA}, \mathrm{AL}$ \\
\hline Bermuda-7 & 50.2 & 39.1 & 9.39 & 13.5 & 9.45 & 14.9 & 1.83 & 2.1 & 4.55 & 0.93 & 0.18 & 0.04 & 0.08 & 4.7 & 100.8 & $\mathrm{MA}, \mathrm{D}, \mathrm{MI}, \mathrm{CA}, \mathrm{AL}$ \\
\hline Bermuda-8 & 53 & 31.8 & 9.92 & 11 & 6.17 & 14.9 & 1.71 & 3.41 & 4.39 & 0.89 & 0.19 & $<0.01$ & 0.08 & 15.1 & 99.6 & $\mathrm{MA}, \mathrm{CL}, \mathrm{Ml}, \mathrm{Q}, \mathrm{AL}, \mathrm{P}$ \\
\hline Bermuda-9 & 54.5 & 35.2 & 8.31 & 11.7 & 10.2 & 15.3 & 1.49 & 1.68 & 3.82 & 0.71 & 0.21 & 0.09 & 0.07 & 10.8 & 99.5 & $\mathrm{MA}, \mathrm{AU}, \mathrm{D}, \mathrm{CL}, \mathrm{MI}, \mathrm{CA}, \mathrm{Q}, \mathrm{AL}$ \\
\hline Bermuda-11 & 60.3 & 41.2 & 14.8 & 9.69 & 9.76 & 7.71 & 1.48 & 2.38 & 1.28 & 0.12 & 0.2 & 0.04 & 0.04 & 11.8 & 100.4 & $\mathrm{AU}, \mathrm{D}, \mathrm{CL}, \mathrm{CA}, \mathrm{Q}, \mathrm{AL}$ \\
\hline Bermuda-12 & 61.5 & 46.8 & 14.8 & 10.8 & 7.65 & 8.05 & 2.81 & 0.85 & 1.34 & 0.14 & 0.17 & 0.04 & 0.05 & 7.03 & 100.6 & $\mathrm{AU}, \mathrm{D}, \mathrm{CL}, \mathrm{CA}, \mathrm{Q}, \mathrm{AL}, \mathrm{H}$ \\
\hline
\end{tabular}

*MA, magnetite; MI, mica (probably phlogopite); AU augite; Z, zeolite; O, olivine; D, diopside; CL, chlorite; CA, calcite; AL, albite; Q, quartz; H, hornblende; P, pyroxene of some kind 
Supplementary Data Table 2. Major and trace element concentrations of Bermuda volcanic rocks. All values in parts per million (ppm) except where noted.

\begin{tabular}{|c|c|c|c|c|c|c|c|c|c|c|c|c|c|c|c|c|c|}
\hline Sample & Depth (m) & $\mathrm{Fe}(\%)$ & Ca (\%) & $\mathrm{Na}(\%)$ & K (\%) & $\mathrm{Rb}$ & $\mathrm{Sr}$ & Cs & $\mathrm{Ba}$ & Th & U & La & $\mathrm{Ce}$ & $\mathrm{Nd}$ & $\mathrm{Sm}$ & $\mathrm{Eu}$ & Gd \\
\hline Bermuda-1 & 38.9 & 9.33 & 9.21 & 2.19 & 1.52 & 58.50 & 1140.00 & 1.36 & 1120.00 & 10.80 & 3.01 & 103.00 & 193.00 & 88.20 & 14.70 & 4.09 & 10.30 \\
\hline Bermuda-3 & 43.6 & 9.77 & 10.30 & 1.49 & 1.47 & 52.60 & 1120.00 & 0.87 & 1040.00 & 9.27 & 2.48 & 91.20 & 173.00 & 79.10 & 13.70 & 3.76 & 10.30 \\
\hline Bermuda-4 & 44.5 & 9.76 & 9.41 & 1.63 & 1.61 & 62.40 & 1020.00 & 0.87 & 991.00 & 9.13 & 2.47 & 90.10 & 167.00 & 76.40 & 13.10 & 3.69 & 10.00 \\
\hline Bermuda-5 & 48.1 & 9.46 & 8.35 & 1.75 & 2.05 & 55.70 & 918.00 & 0.97 & 782.00 & 8.41 & 2.52 & 85.80 & 162.00 & 75.60 & 13.30 & 3.74 & 10.00 \\
\hline Bermuda-6 & 49.2 & 9.53 & 10.30 & 1.36 & 1.72 & 51.70 & 924.00 & 0.54 & 659.00 & 6.29 & 1.86 & 67.00 & 133.00 & 66.70 & 11.70 & 3.28 & 9.07 \\
\hline Bermuda-7 & 50.2 & 9.27 & 9.76 & 1.32 & 1.25 & 50.70 & 944.00 & 0.68 & 744.00 & 6.21 & 1.80 & 68.20 & 133.00 & 68.70 & 11.80 & 3.28 & 8.17 \\
\hline Bermuda-8 & 53 & 7.55 & 9.82 & 1.20 & 2.72 & 68.10 & 1040.00 & 0.62 & 735.00 & 8.31 & 2.27 & 79.20 & 154.00 & 73.40 & 11.80 & 3.30 & 8.54 \\
\hline Bermuda-9 & 54.5 & 8.09 & 10.60 & 1.09 & 1.15 & 40.90 & 2570.00 & 0.63 & 691.00 & 6.47 & 1.83 & 65.20 & 126.00 & 62.20 & 10.60 & 3.02 & 7.54 \\
\hline Bermuda-10 & 57.1 & 9.66 & 9.78 & 0.88 & 2.42 & 39.10 & 1270.00 & 0.13 & 940.00 & 9.44 & 2.76 & 92.80 & 182.00 & 85.20 & 14.70 & 3.99 & 10.30 \\
\hline Bermuda-11 & 60.3 & 6.60 & 5.51 & 1.05 & 1.82 & 40.40 & 167.00 & 0.28 & 341.00 & 0.81 & 0.25 & 7.45 & 21.20 & 14.50 & 3.74 & 1.18 & 3.95 \\
\hline Bermuda-12 & 61.5 & 7.48 & 6.07 & 2.03 & 0.75 & 12.50 & 213.00 & 0.10 & 165.00 & 0.91 & 0.31 & 10.30 & 20.20 & 12.00 & 3.02 & 0.90 & 3.16 \\
\hline
\end{tabular}




\begin{tabular}{|c|c|c|c|c|c|c|c|c|c|c|c|c|c|c|c|}
\hline Tb & Ho & $\mathrm{Tm}$ & Yb & Lu & $\mathrm{Zr}$ & $\mathrm{Hf}$ & Ta & W & Sc & $\mathrm{Cr}$ & Co & $\mathrm{Ni}$ & $\mathrm{Zn}$ & As & $\mathrm{Sb}$ \\
\hline 1.35 & 1.29 & 0.39 & 2.12 & 0.29 & 337.00 & 7.89 & 10.10 & 0.50 & 18.20 & 103.00 & 47.50 & 62.80 & 108.00 & 0.81 & 0.12 \\
\hline 1.25 & 1.29 & 0.37 & 2.06 & 0.29 & 347.00 & 8.09 & 9.14 & 1.00 & 28.30 & 231.00 & 53.60 & 101.00 & 110.00 & 0.85 & 0.15 \\
\hline 1.27 & 1.32 & 0.38 & 2.22 & 0.31 & 339.00 & 7.71 & 8.94 & 1.90 & 26.30 & 190.00 & 54.50 & 92.10 & 108.00 & 1.04 & 0.13 \\
\hline 1.26 & 1.29 & 0.36 & 2.02 & 0.26 & 331.00 & 8.19 & 8.77 & 3.05 & 28.70 & 271.00 & 50.70 & 81.80 & 100.00 & 1.34 & 0.24 \\
\hline 1.14 & 1.12 & 0.31 & 1.72 & 0.24 & 320.00 & 7.97 & 6.64 & 1.48 & 34.60 & 225.00 & 54.60 & 113.00 & 95.80 & 0.76 & 0.16 \\
\hline 1.14 & 1.11 & 0.28 & 1.68 & 0.24 & 306.00 & 7.92 & 6.53 & 1.73 & 35.60 & 310.00 & 55.90 & 134.00 & 88.50 & 0.99 & 0.17 \\
\hline 1.10 & 1.09 & 0.28 & 1.63 & 0.23 & 308.00 & 6.93 & 8.47 & 3.02 & 19.20 & 65.10 & 39.70 & 63.00 & 72.20 & 3.68 & 0.38 \\
\hline 1.01 & 0.91 & 0.25 & 1.47 & 0.21 & 267.00 & 6.89 & 6.67 & 2.99 & 30.30 & 607.00 & 51.40 & 155.00 & 77.00 & 0.84 & 0.19 \\
\hline 1.38 & 1.35 & 0.35 & 2.16 & 0.30 & 378.00 & 8.85 & 9.79 & 1.61 & 17.50 & 33.40 & 48.00 & 53.10 & 99.00 & 3.64 & 0.16 \\
\hline 0.65 & 0.90 & 0.34 & 2.14 & 0.33 & 87.70 & 2.41 & 0.71 & 0.89 & 33.50 & 293.00 & 61.30 & 137.00 & 79.80 & 0.48 & 0.08 \\
\hline 0.55 & 0.80 & 0.33 & 2.06 & 0.33 & 96.90 & 2.57 & 0.78 & 3.01 & 35.40 & 304.00 & 51.60 & 131.00 & 93.20 & 1.89 & 0.11 \\
\hline
\end{tabular}


Supplementary Data Table 3. Major and trace element concentrations of Bermuda soils and paleosols. All values in parts per per million (ppm) except where noted.

\begin{tabular}{|c|c|c|c|c|c|c|c|c|c|c|c|c|c|c|c|}
\hline Locality & Latitude $\left({ }^{\circ} \mathrm{N}\right)$ & Longitude $\left({ }^{\circ} \mathrm{W}\right)$ & Sample \# & $\mathrm{Fe}(\%)$ & $\mathrm{Ca}(\%)$ & $\mathrm{Na}(\%)$ & $\mathrm{K}(\%)$ & notes on $\mathrm{K}$ & $\mathrm{Rb}$ & $\mathrm{Sr}$ & Cs & $\mathrm{Ba}$ & Th & U & La \\
\hline Coney Island & 32.3596 & 64.7152 & $\mathrm{CN}-1$ & 0.23 & 35.80 & 0.40 & 0.02 & $\mathrm{cv}<$ & 1.72 & 4690.00 & 0.32 & 15.20 & 0.99 & 2.32 & 7.66 \\
\hline Coney Island & 32.3596 & 64.7152 & $\mathrm{CN}-2$ & 0.41 & 35.30 & 0.60 & 0.05 & & 1.94 & 4380.00 & 0.52 & 25.00 & 2.10 & 2.37 & 16.10 \\
\hline ESSO Tank (Shore Hills) & 32.372 & 64.6986 & $E-20$ & 10.80 & 8.02 & 0.07 & 0.03 & $\mathrm{cv}<$ & 48.20 & 17000.00 & 10.90 & 665.00 & 30.80 & 10.60 & 252.00 \\
\hline ESSO Tank (Shore Hills) & 32.372 & 64.6986 & $\mathrm{E}-21$ & 10.80 & 8.09 & 0.24 & 0.01 & $\mathrm{cV}<$ & 49.50 & 16500.00 & 11.40 & 616.00 & 34.20 & 10.60 & 272.00 \\
\hline ESSO Tank (Shore Hills) & 32.372 & 64.6986 & E-22 & 10.30 & 6.86 & 0.86 & 1.00 & & 44.20 & 15700.00 & 11.40 & 596.00 & 42.70 & 13.70 & 330.00 \\
\hline ESSO Tank (Shore Hills) & 32.372 & 64.6986 & $\mathrm{E}-23$ & 2.69 & 28.20 & 0.07 & 0.35 & & 15.70 & 4180.00 & 2.90 & 175.00 & 14.90 & 4.13 & 108.00 \\
\hline Vesey Road & 32.3099 & 64.7563 & EQV-1 & 7.67 & 10.70 & 0.07 & 0.46 & & 27.20 & 643.00 & 8.65 & 117.00 & 36.70 & 11.00 & 275.00 \\
\hline Vesey Road & 32.3099 & 64.7563 & EQV-2 & 0.84 & 36.20 & 0.11 & 0.15 & & 8.83 & 2760.00 & 1.69 & 26.30 & 3.52 & 1.98 & 21.20 \\
\hline Vesey Road & 32.3099 & 64.7563 & EQV-3 & 1.39 & 30.70 & 0.13 & 0.14 & & 12.50 & 4460.00 & 2.40 & 64.60 & 5.25 & 3.09 & 31.30 \\
\hline Vesey Road & 32.3099 & 64.7563 & EQV-6 & 0.27 & 37.40 & 0.19 & 0.09 & & 2.04 & 4970.00 & 0.50 & 20.10 & 1.27 & 2.42 & 10.60 \\
\hline Vesey Road & 32.3099 & 64.7563 & EQV-7 & 1.73 & 29.70 & 0.13 & 0.10 & $\mathrm{cv}<$ & 11.40 & 4920.00 & 2.46 & 101.00 & 6.77 & 3.46 & 40.70 \\
\hline Vesey Road & 32.3099 & 64.7563 & EQV-8 & 8.77 & 6.46 & 0.11 & 0.96 & & 27.90 & 13400.00 & 9.16 & 533.00 & 34.10 & 9.19 & 211.00 \\
\hline Fort Scaur & 32.2869 & 64.8703 & FS-1 & 0.37 & 39.20 & 0.20 & 0.13 & & 2.76 & 3480.00 & 0.63 & 27.70 & 1.40 & 1.82 & 8.15 \\
\hline Fort Scaur & 32.2869 & 64.8703 & FS-4 & 0.20 & 39.90 & 0.16 & 0.02 & $\mathrm{cv}<$ & 1.98 & 4000.00 & 0.35 & 19.50 & 0.85 & 2.11 & 5.29 \\
\hline Grape Bay Railroad cut & 32.2868 & 64.7718 & GRR-1 & 3.79 & 29.50 & 0.33 & 0.37 & & 42.20 & 3790.00 & 9.42 & 112.00 & 15.10 & 3.55 & 117.00 \\
\hline Grape Bay Railroad cut & 32.2868 & 64.7718 & GRR-3 & 2.56 & 31.10 & 0.66 & 0.11 & & 30.00 & 5550.00 & 6.48 & 94.10 & 10.40 & 3.26 & 82.00 \\
\hline Grape Bay Railroad cut & 32.2868 & 64.7718 & GRR-4 & 0.58 & 37.90 & 0.26 & 0.18 & & 3.97 & 4130.00 & 0.96 & 29.30 & 2.34 & 2.06 & 18.20 \\
\hline Grape Bay Railroad cut & 32.2868 & 64.7718 & GRR-5 & 0.97 & 36.80 & 0.52 & 0.03 & $\mathrm{cr}<$ & 11.20 & 4080.00 & 2.47 & 34.90 & 3.86 & 2.16 & 32.10 \\
\hline Ireland Island & 32.3241 & 64.8358 & IRE-1 & 2.90 & 34.70 & 0.50 & 0.10 & & 15.20 & 3680.00 & 4.33 & 81.90 & 10.40 & 4.33 & 48.10 \\
\hline Ireland Island & 32.3241 & 64.8358 & IRE-4 & 1.10 & 36.10 & 0.64 & 0.03 & $\mathrm{cv}<$ & 4.54 & 4320.00 & 1.61 & 46.80 & 3.94 & 3.29 & 19.00 \\
\hline Ferry Road and Railroad Trail & 32.3708 & 64.7015 & PR-1 & 0.33 & 37.20 & 0.27 & 0.18 & & 2.10 & 6370.00 & 0.44 & 25.40 & 1.25 & 3.18 & 9.28 \\
\hline Ferry Road and Railroad Trail & 32.3708 & 64.7015 & PR-2 & 1.86 & 33.30 & 0.22 & 0.28 & & 14.90 & 6220.00 & 3.01 & 69.30 & 7.15 & 3.75 & 47.30 \\
\hline Ferry Road and Railroad Trail & 32.3708 & 64.7015 & PR-3 & 4.24 & 22.80 & 0.23 & 0.39 & & 31.90 & 4350.00 & 7.34 & 132.00 & 16.30 & 4.26 & 105.00 \\
\hline Ferry Road and Railroad Trail & 32.3708 & 64.7015 & PR-4 & 8.44 & 9.54 & 0.53 & 0.17 & $\mathrm{cr}<$ & 67.10 & 2350.00 & 14.70 & 239.00 & 32.80 & 5.55 & 208.00 \\
\hline Ferry Road and Railroad Trail & 32.3708 & 64.7015 & PR-5 & 4.76 & 22.30 & 0.10 & 0.15 & $\mathrm{cv}<$ & 25.10 & 2130.00 & 6.01 & 167.00 & 18.00 & 8.83 & 124.00 \\
\hline Paynter's Road & 32.3345 & 64.703 & PY-2 & 0.29 & 40.10 & 0.27 & 0.10 & $\mathrm{cr}<$ & 4.64 & 5230.00 & 0.43 & 28.00 & 1.19 & 1.79 & 13.20 \\
\hline Paynter's Road & 32.3345 & 64.703 & PY-3 & 9.47 & 6.76 & 0.11 & 1.88 & & 52.00 & 12900.00 & 18.70 & 647.00 & 45.40 & 12.70 & 236.00 \\
\hline Government quarry & 32.3404 & 64.7033 & Q-10 & 9.52 & 7.11 & 0.12 & 1.35 & & 68.80 & 15600.00 & 14.10 & 636.00 & 35.90 & 7.46 & 223.00 \\
\hline Rocky Bay Hill & 32.2985 & 64.7455 & RBD-2 & 3.01 & 24.90 & 1.37 & 0.12 & & 33.70 & 2570.00 & 4.75 & 105.00 & 12.00 & 2.69 & 59.00 \\
\hline Rocky Bay Hill & 32.2985 & 64.7455 & RBD-4 & 0.56 & 35.80 & 1.06 & 0.20 & & 4.76 & 3770.00 & 0.87 & 35.10 & 2.44 & 1.84 & 13.90 \\
\hline Rocky Bay Hill & 32.2985 & 64.7455 & RBD-5 & 4.84 & 22.10 & 0.57 & 0.19 & & 15.00 & 727.00 & 5.54 & 84.50 & 18.80 & 4.16 & 98.40 \\
\hline Spice Hill Road (Khyber Pass) & 32.2654 & 64.8045 & SHR-1 & 0.55 & 38.50 & 0.73 & 0.27 & & 4.79 & 2120.00 & 1.17 & 15.90 & 2.10 & 1.41 & 14.80 \\
\hline Spice Hill Road (Khyber Pass) & 32.2654 & 64.8045 & SHR-2 & 1.47 & 33.00 & 0.68 & 0.21 & & 13.80 & 4550.00 & 3.07 & 45.70 & 6.11 & 2.93 & 37.40 \\
\hline Whalebone Bay & 32.3654 & 64.7137 & W-40 & 4.60 & 25.90 & 1.40 & 0.45 & & 11.50 & 916.00 & 2.66 & 68.80 & 72.00 & 13.90 & 505.00 \\
\hline Whalebone Bay & 32.3654 & 64.7137 & W-40 (dupl & | 4.92 & 21.20 & 1.46 & 0.49 & & 20.90 & 867.00 & 2.66 & 86.90 & 78.10 & 13.70 & 552.00 \\
\hline Whalebone Bay & 32.3654 & 64.7137 & W-42 & 6.67 & 16.30 & 0.55 & 0.76 & & 16.60 & 1080.00 & 4.45 & 92.00 & 81.40 & 11.90 & 560.00 \\
\hline Whalebone Bay & 32.3654 & 64.7137 & W-43 & 0.19 & 39.70 & 0.54 & 0.16 & & 1.33 & 4420.00 & 0.15 & 11.50 & 1.09 & 1.89 & 9.69 \\
\hline Whalebone Bay & 32.3654 & 64.7137 & W-44A & 5.45 & 20.40 & 2.31 & 0.18 & & 18.10 & 885.00 & 4.53 & 120.00 & 68.70 & 12.60 & 457.00 \\
\hline Whalebone Bay & 32.3654 & 64.7137 & W-45 & 0.22 & 40.80 & 0.28 & 0.22 & & 1.03 & 5030.00 & 0.24 & 20.90 & 6.02 & 2.89 & 36.90 \\
\hline Whalebone Bay & 32.3654 & 64.7137 & W-50 & 4.73 & 32.00 & 0.14 & 0.05 & $d \mathrm{~d}<<$ & 2.91 & 1880.00 & 0.30 & 273.00 & 405.00 & 79.90 & 2980.00 \\
\hline Whalebone Bay & 32.3654 & 64.7137 & W-52 & 0.17 & 39.70 & 1.30 & 0.36 & & 1.21 & 4650.00 & 0.16 & 17.50 & 1.64 & 2.21 & 13.00 \\
\hline Whale Bay Road 1 (Zion Church) & 32.2573 & 64.8688 & Z-01 & 0.76 & 31.40 & 0.17 & 0.07 & $\mathrm{cv}<$ & 6.36 & 3140.00 & 1.15 & 32.10 & 2.79 & 1.96 & 18.00 \\
\hline Whale Bay Road 1 (Zion Church) & 32.2573 & 64.8688 & $\mathrm{Z}-02$ & 1.66 & 34.40 & 0.23 & 0.21 & & 10.00 & 5160.00 & 2.55 & 41.70 & 6.70 & 3.30 & 37.60 \\
\hline Whale Bay Road 1 (Zion Church) & 32.2573 & 64.8688 & Z-03 & 7.62 & 9.18 & 0.34 & 0.44 & & 36.30 & 607.00 & 12.50 & 147.00 & 30.70 & 5.84 & 145.00 \\
\hline Whale Bay Road 1 (Zion Church) & 32.2573 & 64.8688 & Z-04 & 7.85 & 8.17 & 0.40 & 0.22 & & 36.30 & 718.00 & 13.40 & 151.00 & 32.10 & 5.54 & 160.00 \\
\hline Whale Bay Road 1 (Zion Church) & 32.2573 & 64.8688 & Z-05 & 3.47 & 21.60 & 0.16 & 0.23 & & 18.30 & 1110.00 & 6.95 & 101.00 & 18.30 & 4.11 & 90.30 \\
\hline Whale Bay Road 1 (Zion Church) & 32.2573 & 64.8688 & Z-06 & 0.97 & 33.80 & 0.14 & 0.09 & $\mathrm{cv}<$ & 6.66 & 2770.00 & 1.45 & 33.70 & 3.72 & 2.10 & 23.50 \\
\hline Whale Bay Road 1 (Zion Church) & 32.2573 & 64.8688 & Z-07 & 8.20 & 6.12 & 0.33 & 0.52 & & 42.10 & 678.00 & 13.40 & 189.00 & 32.30 & 6.74 & 148.00 \\
\hline Whale Bay Road 2 & 32.256 & 64.8701 & ZZ-10 & 0.70 & 35.30 & 0.16 & 0.96 & & 3.57 & 3670.00 & 0.92 & 34.80 & 2.72 & 1.76 & 17.80 \\
\hline Whale Bay Road 2 & 32.256 & 64.8701 & $\mathrm{ZZ}-12$ & 1.01 & 33.50 & 0.51 & 0.60 & $\mathrm{cv}<$ & 5.57 & 3950.00 & 1.39 & 43.90 & 3.95 & 1.90 & 24.10 \\
\hline Whale Bay Road 2 & 32.256 & 64.8701 & ZZ-11 & 0.96 & 36.30 & 0.45 & 0.26 & & 4.20 & 2460.00 & 1.22 & 39.40 & 3.78 & 1.93 & 23.00 \\
\hline Whale Bay Road 2 & 32.256 & 64.8701 & ZZ-13 & 0.45 & 38.20 & 0.22 & 0.08 & $\mathrm{cv}<$ & 3.34 & 3370.00 & 0.75 & 32.20 & 1.79 & 1.80 & 11.50 \\
\hline Whale Bay Road 2 & 32.256 & 64.8701 & ZZ-16 & 0.67 & 36.40 & 0.46 & 0.20 & & 4.37 & 3030.00 & 0.97 & 39.20 & 3.13 & 1.77 & 19.00 \\
\hline
\end{tabular}


NOTES:

$\mathrm{cr}<=$ coefficient of variation exceeds $30 \%$

$\mathrm{dl}<<=$ below empirical detection limit

ic $<=$ interference correction exceeds $60 \%$ 


\begin{tabular}{|c|c|c|c|c|c|c|c|c|c|c|c|c|c|c|c|c|c|c|}
\hline $\mathrm{Ce}$ & $\mathrm{Nd}$ & $\mathrm{Sm}$ & $\mathrm{Eu}$ & $\mathrm{Gd}$ & $\mathrm{Tb}$ & Ho & $\mathrm{Tm}$ & $\mathrm{Yb}$ & Lu & $\mathrm{Zr}$ & notes on $\mathrm{Zr}$ & $\mathrm{Hf}$ & Ta & W & notes on W & $\mathrm{Sc}$ & $\mathrm{Cr}$ & Co \\
\hline 10.50 & 8.16 & 1.88 & 0.43 & 2.22 & 0.36 & 0.54 & 0.23 & 1.50 & 0.21 & 15.90 & $\mathrm{cV}<$ & 0.21 & 0.18 & 0.33 & & 1.50 & 44.10 & 0.54 \\
\hline 23.70 & 15.80 & 3.50 & 0.81 & 3.93 & 0.63 & 0.92 & 0.40 & 2.44 & 0.35 & 34.60 & & 0.37 & 0.59 & 0.13 & & 2.56 & 76.70 & 0.87 \\
\hline 422.00 & 221.00 & 49.50 & 12.40 & 51.00 & 8.46 & 12.30 & 4.60 & 27.30 & 3.51 & 880.00 & & 13.20 & 10.50 & 5.33 & & 76.30 & 696.00 & 15.40 \\
\hline 473.00 & 243.00 & 51.60 & 12.90 & 53.10 & 8.46 & 12.30 & 4.83 & 27.70 & 3.75 & 949.00 & & 13.90 & 13.80 & 3.23 & & 71.00 & 813.00 & 15.90 \\
\hline 597.00 & 285.00 & 59.30 & 14.60 & 55.50 & 8.45 & 12.50 & 4.90 & 27.80 & 3.79 & 938.00 & & 14.70 & 24.10 & 6.28 & & 72.80 & 897.00 & 27.00 \\
\hline 200.00 & 99.50 & 18.10 & 4.50 & 17.80 & 2.56 & 3.48 & 1.47 & 8.66 & 1.21 & 237.00 & & 3.76 & 8.43 & 1.94 & & 17.60 & 366.00 & 7.75 \\
\hline 315.00 & 343.00 & 78.20 & 18.60 & 107.00 & 17.10 & 29.00 & 13.60 & 84.20 & 12.10 & 822.00 & & 6.59 & 2.13 & 2.88 & ic $<$ & 76.40 & 883.00 & 17.70 \\
\hline 28.60 & 23.10 & 5.48 & 1.26 & 7.06 & 1.09 & 1.59 & 0.66 & 3.89 & 0.56 & 66.50 & & 0.87 & 0.26 & 0.28 & & 5.46 & 59.10 & 2.77 \\
\hline 45.40 & 34.30 & 7.67 & 1.70 & 8.60 & 1.50 & 2.42 & 1.04 & 6.58 & 0.94 & 79.60 & & 1.33 & 0.43 & 0.59 & & $\begin{array}{l}7.70 \\
7.82\end{array}$ & 98.50 & 3.56 \\
\hline 12.40 & 10.90 & 2.43 & 0.50 & 2.75 & 0.39 & 0.60 & 0.23 & 1.40 & 0.19 & 17.80 & $\mathrm{cV}<$ & 0.27 & 0.09 & 0.53 & & 1.97 & 22.00 & 1.26 \\
\hline 58.70 & 44.50 & 9.85 & 2.23 & 12.50 & 1.97 & 2.93 & 1.31 & 8.63 & 1.23 & 113.00 & & 1.64 & 0.55 & 1.69 & & 10.10 & 128.00 & 4.36 \\
\hline 315.00 & 217.00 & 47.20 & 11.10 & 64.10 & 9.90 & 13.90 & 5.18 & 34.00 & 4.60 & 614.00 & & 8.45 & 3.03 & 4.21 & & 41.00 & 566.00 & 15.50 \\
\hline 11.40 & 8.51 & 1.88 & 0.44 & 2.34 & 0.39 & 0.64 & 0.29 & 1.74 & 0.25 & 27.30 & & 0.39 & 0.13 & 0.27 & & 2.32 & 52.00 & 0.75 \\
\hline 7.00 & 5.70 & 1.30 & 0.30 & 1.53 & 0.27 & 0.44 & 0.18 & 1.15 & 0.17 & 15.00 & $\mathrm{cV}<$ & 0.20 & 0.07 & 0.21 & & 1.37 & 26.80 & 0.43 \\
\hline 147.00 & 118.00 & 27.50 & 6.75 & 40.10 & 6.24 & 9.76 & 3.94 & 24.10 & 3.34 & 363.00 & & 3.42 & 1.23 & 1.27 & & 24.00 & 211.00 & 12.10 \\
\hline 101.00 & 81.90 & 19.20 & 4.67 & 27.50 & 4.04 & 6.22 & 2.49 & 13.60 & 1.87 & 221.00 & & 2.50 & 0.86 & 1.29 & & 13.90 & 162.00 & 9.18 \\
\hline 21.80 & 18.30 & 4.40 & 1.07 & 5.67 & 0.98 & 1.47 & 0.70 & 4.08 & 0.59 & 51.90 & & 0.59 & 0.19 & 0.24 & & 4.40 & 95.10 & 1.71 \\
\hline 38.10 & 32.20 & 7.23 & 1.72 & 9.54 & 1.45 & 2.00 & 0.70 & 3.98 & 0.54 & 73.60 & & 0.83 & 0.31 & 0.26 & ic $<$ & 5.62 & 51.40 & 5.27 \\
\hline 75.10 & 46.60 & 9.59 & 2.09 & 11.40 & 1.81 & 2.88 & 1.32 & 8.07 & 1.21 & 161.00 & & 3.04 & 0.98 & 0.63 & & 12.10 & 227.00 & 5.06 \\
\hline 28.80 & 17.20 & 3.79 & 0.79 & 4.39 & 0.65 & 0.91 & 0.43 & 2.57 & 0.38 & 58.90 & & $\begin{array}{l}1.16 \\
\text { S }\end{array}$ & 0.37 & 0.80 & & 4.39 & 86.30 & 2.56 \\
\hline 11.90 & 10.10 & 2.37 & 0.53 & 3.23 & 0.46 & 0.71 & 0.28 & 1.66 & 0.24 & 34.10 & $\mathrm{cV}<$ & 0.30 & 0.14 & 0.47 & & 2.22 & 52.20 & 0.82 \\
\hline 64.20 & 46.30 & 10.50 & 2.41 & 12.70 & 2.04 & 3.08 & 1.19 & 7.05 & 1.01 & 128.00 & & 1.78 & 0.85 & 0.93 & & 10.20 & 203.00 & 4.14 \\
\hline 140.00 & 99.20 & 21.40 & 5.02 & 26.40 & 4.12 & 6.02 & 2.58 & 15.20 & 2.10 & 261.00 & & 4.10 & 1.84 & 1.72 & & 21.50 & 462.00 & 8.99 \\
\hline 282.00 & 204.00 & 43.40 & 10.30 & 55.80 & 8.50 & 13.00 & 5.41 & 31.80 & 4.54 & 568.00 & & 8.16 & 3.91 & 1.25 & ic $<$ & 46.00 & 888.00 & 17.60 \\
\hline 164.00 & 128.00 & 28.80 & 7.20 & 42.60 & 6.49 & 9.99 & 5.23 & 31.80 & 4.72 & 378.00 & & 4.29 & 2.34 & 0.12 & ic $<$ & 29.70 & 441.00 & 12.60 \\
\hline 13.80 & 13.40 & 3.10 & 0.74 & $\begin{array}{l}4.15 \\
4.06\end{array}$ & 0.64 & 1.04 & 0.39 & 2.43 & 0.35 & 38.60 & & 0.31 & 0.11 & 0.72 & & 2.71 & 28.70 & 2.04 \\
\hline 392.00 & 218.00 & 47.10 & 9.89 & 57.30 & 8.65 & 13.60 & 6.00 & 35.10 & 4.59 & 987.00 & & 20.80 & 8.45 & 2.60 & ic $<$ & 45.30 & 803.00 & 17.10 \\
\hline 294.00 & 218.00 & 51.60 & 12.10 & 69.60 & 10.90 & 18.40 & 8.56 & 52.70 & 7.87 & 579.00 & & 5.47 & 2.07 & 0.06 & ic $<$ & 58.90 & 758.00 & 32.20 \\
\hline 85.60 & 55.10 & 11.90 & 2.74 & 14.40 & 2.36 & $\begin{array}{l}3.49 \\
3.49\end{array}$ & 1.40 & 8.37 & 1.12 & 175.00 & & $\begin{array}{l}2.41 \\
2.99\end{array}$ & 1.03 & 1.17 & & 13.00 & 215.00 & 3.42 \\
\hline 19.30 & 13.70 & 3.05 & 0.71 & 4.32 & 0.63 & 1.01 & 0.39 & 2.17 & 0.25 & 32.80 & & 0.54 & 0.21 & 0.50 & $d \mid<<$ & 3.49 & 53.60 & 0.74 \\
\hline 155.00 & 83.60 & 19.50 & 4.67 & 25.20 & 4.39 & 6.30 & 2.45 & 14.70 & 1.93 & 304.00 & & 4.64 & 1.61 & 2.75 & & 20.60 & 357.00 & 7.92 \\
\hline 20.30 & 14.80 & $\begin{array}{l}3.00 \\
3.80\end{array}$ & $\begin{array}{l}1.00 \\
1.00\end{array}$ & 6.23 & 1.06 & 2.34 & $\begin{array}{l}1.19 \\
1.19\end{array}$ & 7.35 & 1.05 & 61.50 & & 0.57 & 0.17 & 0.78 & & $\begin{array}{l}2.00 \\
6.17\end{array}$ & 48.90 & $\begin{array}{l}1.52 \\
1.65\end{array}$ \\
\hline 49.60 & 36.80 & 8.32 & 1.98 & 11.40 & 1.74 & 2.33 & 0.88 & 5.42 & 0.73 & 110.00 & & 1.55 & 0.50 & 0.50 & $\mathrm{dl}<<<$ & 7.52 & 88.40 & 3.75 \\
\hline 1040.00 & 448.00 & 73.70 & 18.50 & 62.10 & 7.26 & 6.50 & 2.15 & 11.30 & 1.38 & 623.00 & & 6.38 & 51.10 & 0.50 & $\mathrm{dl}<<$ & 15.60 & 2320.00 & 13.30 \\
\hline 1200.00 & 493.00 & 72.00 & 20.30 & 63.90 & 7.34 & 7.43 & nd & 11.90 & 1.57 & 566.00 & & 5.21 & 56.20 & 2.09 & ic $<$ & 16.50 & 3140.00 & 14.80 \\
\hline 1150.00 & 552.00 & 74.00 & 20.90 & 65.20 & 8.10 & 7.87 & nd & 14.30 & 1.92 & 727.00 & & 6.98 & 54.00 & 0.33 & ic $<$ & 24.90 & 2810.00 & 21.60 \\
\hline 15.70 & 8.46 & 1.72 & 0.38 & $\begin{array}{l}1.92 \\
\text { l. }\end{array}$ & 0.25 & 0.33 & 0.16 & 0.86 & 0.12 & 13.50 & $\mathrm{cv}<$ & 0.14 & 0.58 & 0.53 & $\mathrm{cv}<$ & 0.98 & 47.70 & 0.49 \\
\hline 942.00 & 395.00 & 63.70 & 16.50 & 49.90 & 6.57 & 7.35 & 2.32 & 12.00 & 1.48 & 620.00 & & 6.69 & 45.10 & 5.51 & & 20.50 & 2360.00 & 15.50 \\
\hline 75.30 & 35.10 & 5.44 & 1.31 & 4.16 & 0.50 & 0.64 & 0.18 & 1.01 & 0.14 & 39.20 & & 0.27 & 3.45 & 1.14 & & 1.15 & 127.00 & 0.68 \\
\hline 5740.00 & 2400.00 & 321.00 & 87.80 & nd & 23.00 & nd & nd & 11.50 & 1.20 & 1870.00 & & 10.10 & 310.00 & 0.50 & $d \mid<<$ & 8.01 & 15600.00 & 25.50 \\
\hline 23.00 & 11.20 & 2.09 & 0.49 & 1.95 & 0.26 & 0.36 & 0.15 & 0.84 & 0.12 & 13.90 & $\mathrm{cV}<$ & 0.13 & 1.01 & 0.50 & $\mathrm{~d} l<<$ & 0.93 & 39.80 & 0.38 \\
\hline 23.60 & 17.80 & 4.20 & 0.95 & 5.10 & 0.83 & 1.17 & 0.50 & 3.14 & 0.48 & 49.80 & & 0.73 & 0.24 & 0.75 & & 4.10 & 63.80 & 1.85 \\
\hline 58.40 & 40.50 & 8.90 & 2.00 & 11.40 & 1.65 & 2.30 & 0.86 & 5.31 & 0.74 & 99.60 & & 1.68 & 0.54 & 0.66 & & 8.58 & 129.00 & 3.88 \\
\hline 236.00 & 147.00 & 32.60 & 7.62 & 41.30 & 6.93 & 10.20 & 4.50 & 26.70 & 3.81 & 467.00 & & 8.21 & 2.55 & 1.77 & & 39.40 & 507.00 & 15.10 \\
\hline 248.00 & 171.00 & 38.30 & 9.12 & 50.30 & 8.27 & 12.30 & 5.08 & 31.30 & 4.46 & 528.00 & & 8.74 & 2.64 & 0.73 & ic $<$ & 46.20 & 558.00 & 17.70 \\
\hline $\begin{array}{l}143.00 \\
0\end{array}$ & 93.30 & 20.70 & $\begin{array}{l}4.12 \\
4.99\end{array}$ & 30.00 & 4.75 & 7.69 & $\begin{array}{l}3.35 \\
3.35\end{array}$ & 20.60 & $\begin{array}{l}3.402 \\
3.02\end{array}$ & 317.00 & & 4.91 & 1.50 & 1.35 & & 28.40 & 359.00 & 7.15 \\
\hline 30.50 & 23.30 & 5.52 & 1.26 & 7.38 & 1.09 & 1.61 & 0.70 & 4.21 & 0.61 & 68.30 & & 1.00 & 0.31 & 1.09 & & 5.47 & 75.20 & 2.43 \\
\hline 233.00 & 141.00 & 32.10 & 7.34 & 39.80 & 6.64 & 10.10 & 4.17 & 25.90 & 3.68 & 450.00 & & 8.75 & 2.80 & 0.44 & ic $<$ & 33.20 & 587.00 & 15.80 \\
\hline 23.60 & 18.30 & 4.06 & 0.95 & 5.26 & 0.86 & 1.23 & 0.58 & 3.43 & 0.50 & 53.90 & & 0.67 & 0.23 & 0.40 & & 4.50 & 83.50 & 1.30 \\
\hline 32.50 & 25.30 & 5.30 & 1.22 & 6.68 & 1.04 & 1.58 & 0.69 & 4.06 & 0.57 & 67.40 & & 1.03 & 0.34 & 0.61 & & 5.44 & 102.00 & 2.73 \\
\hline 30.40 & 22.70 & 5.17 & 1.19 & 7.03 & 1.06 & 1.66 & 0.73 & 4.07 & 0.58 & 65.90 & & 0.98 & 0.30 & 0.40 & & 5.26 & 103.00 & 2.04 \\
\hline 15.70 & 12.10 & 2.65 & 0.62 & 3.67 & 0.53 & 0.81 & 0.33 & 1.86 & 0.26 & 29.00 & & 0.45 & 0.16 & 0.26 & & 2.30 & 58.60 & 1.21 \\
\hline 24.90 & 18.80 & 4.14 & 0.94 & 4.94 & 0.81 & 1.08 & 0.45 & 2.78 & 0.39 & 46.50 & & 0.81 & 0.27 & 1.88 & & 4.10 & 100.00 & 1.17 \\
\hline
\end{tabular}





\begin{tabular}{|c|c|c|c|c|}
\hline $\mathrm{Ni}$ & Notes on $\mathrm{Ni}$ & $\mathrm{Zn}$ & As & $\mathrm{Sb}$ \\
\hline 7.32 & & 4.20 & 3.19 & 0.09 \\
\hline 7.71 & & 6.47 & 5.39 & 0.16 \\
\hline 76.20 & & 445.00 & 46.00 & 1.84 \\
\hline 86.90 & & 428.00 & 44.80 & 1.81 \\
\hline 117.00 & & 481.00 & 45.20 & 1.85 \\
\hline 32.80 & & 90.00 & 18.90 & 0.67 \\
\hline 65.20 & & 112.00 & 43.10 & 1.69 \\
\hline 33.80 & & 48.90 & 5.91 & 0.22 \\
\hline 9.55 & ic $<$ & 30.10 & 7.20 & 0.38 \\
\hline 12.80 & & 4.38 & 2.22 & 0.12 \\
\hline 14.80 & ic $<$ & 33.20 & 8.01 & 0.42 \\
\hline 58.00 & & 160.00 & 38.10 & 1.88 \\
\hline 14.80 & & 7.13 & 5.07 & 0.10 \\
\hline 7.35 & & 3.60 & 2.46 & 0.06 \\
\hline 61.50 & & 161.00 & 28.60 & 0.92 \\
\hline 104.00 & & 108.00 & 23.00 & 0.69 \\
\hline 23.10 & & 17.30 & 4.74 & 0.18 \\
\hline 58.60 & & 37.70 & 11.90 & 0.30 \\
\hline 32.80 & & 26.30 & 15.40 & 0.53 \\
\hline 27.20 & & 9.31 & 4.68 & 0.33 \\
\hline 11.30 & & 4.55 & 2.87 & 0.11 \\
\hline 40.20 & & 24.40 & 13.10 & 0.40 \\
\hline 64.00 & & 51.30 & 29.10 & 0.80 \\
\hline 95.80 & & 88.20 & 40.40 & 1.58 \\
\hline 53.90 & & 64.80 & 24.00 & 0.84 \\
\hline 13.00 & & 19.20 & 2.61 & 0.08 \\
\hline 89.40 & & 299.00 & 39.50 & 2.19 \\
\hline 89.80 & & 244.00 & 36.60 & 1.56 \\
\hline 45.20 & & 38.40 & 36.70 & 0.64 \\
\hline 7.69 & & 8.74 & 9.74 & 0.21 \\
\hline 23.90 & ic $<$ & 54.50 & 21.50 & 0.84 \\
\hline 16.70 & & 11.70 & 4.90 & 0.12 \\
\hline 49.90 & & 22.20 & 12.80 & 0.33 \\
\hline 77.80 & ic $<$ & 60.00 & 71.90 & 1.24 \\
\hline 106.00 & ic $<$ & 66.10 & 60.70 & 1.39 \\
\hline 157.00 & ic $<$ & 96.50 & 108.00 & 2.17 \\
\hline 7.57 & & 2.92 & 2.59 & 0.09 \\
\hline 108.00 & ic $<$ & 73.20 & 100.00 & 1.84 \\
\hline 4.59 & ic $<$ & 3.02 & 2.92 & 0.14 \\
\hline 155.00 & $\mathrm{cV}<$ & 84.40 & 15.20 & 1.47 \\
\hline 5.90 & & 2.45 & 2.84 & 0.09 \\
\hline 9.70 & & 25.10 & 4.71 & 0.24 \\
\hline 38.90 & & 20.20 & 14.10 & 0.30 \\
\hline 59.20 & & 65.00 & 61.50 & 1.14 \\
\hline 77.10 & & 70.80 & 37.80 & 1.21 \\
\hline 37.80 & & 41.30 & 20.20 & 0.50 \\
\hline 7.29 & & 15.40 & 5.02 & 0.19 \\
\hline 89.90 & & 70.60 & 78.00 & 1.21 \\
\hline 13.10 & & 8.66 & 8.18 & 0.14 \\
\hline 30.80 & & 13.30 & 9.64 & 0.27 \\
\hline 19.30 & & 13.70 & 13.30 & 0.21 \\
\hline 10.70 & & 5.86 & 5.82 & 0.13 \\
\hline & & 17.30 & & 0.16 \\
\hline
\end{tabular}


